FERNANDO LUCAS DE MELO

\title{
CARACTERIZAÇÃO BIOLÓGICA E MOLECULAR DE RECOMBINANTES NATURAIS DE HIV-1
}

Tese apresentada ao Departamento de Microbiologia do Instituto de Ciências Biomédicas da Universidade de São Paulo, para obtenção do Título de Doutor em Ciências. 
FERNANDO LUCAS DE MELO

\section{CARACTERIZAÇÃO BIOLÓGICA E MOLECULAR DE RECOMBINANTES NATURAIS DE HIV-1}

Tese apresentada ao Departamento de Microbiologia do Instituto de Ciências Biomédicas da Universidade de São Paulo, para obtenção do Título de Doutor em Ciências.

Área de concentração: Microbiologia

Orientador: Prof. Dr. Paolo Marinho de Andrade Zanotto 
DADOS DE CATALOGAÇÃO NA PUBLICAÇÃO (CIP)

Serviço de Biblioteca e Informação Biomédica do

Instituto de Ciências Biomédicas da Universidade de São Paulo

@ reprodução total

Melo, Fernando Lucas de.

Caracterização biológica e molecular de recombinantes naturais de HIV-1 / Fernando Lucas de Melo. -- São Paulo, 2011.

Orientador: Paolo Marinho Andrade Zanotto.

Tese (Doutorado) - Universidade de São Paulo. Instituto de Ciências Biomédicas. Departamento de Microbiologia. Área de concentração: Microbiologia. Linha de pesquisa: Evolução molecular de microrganismos.

Versão do título para o inglês: Biological and molecular characterization of HIV-1 natural recombinants

Descritores: 1. HIV 2. Genomas 3. Filogenia 4. Evolução molecular 5. Recombinação genética 6. Diversidade genética I. Zanotto, Paolo Marinho Andrade II. Universidade de São Paulo. Instituto de Ciências Biomédicas. Programa de Pós-Graduação em Microbiologia III. Título. 
Candidato(a):

Título da Tese:
Fernando Lucas de Melo.

Caracterização biológica e molecular de recombinantes naturais de HIV-1.

Orientador(a):

Paolo Marinho Andrade Zanotto.

A Comissão Julgadora dos trabalhos de Defesa da Tese de Doutorado, em sessão pública realizada a .$/$. considerou

\section{( ) Aprovado(a) ( ) Reprovado(a)}

\begin{tabular}{|c|c|}
\hline Examinador(a): & 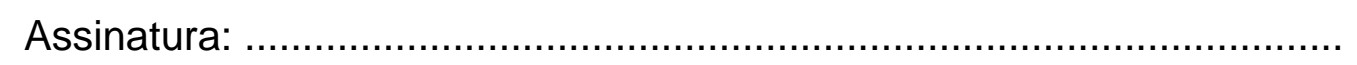 \\
\hline & Nome: ... \\
\hline & Instituição: ... \\
\hline Examinador(a): & Assinatura: \\
\hline & Nome: .......... \\
\hline & Instituição: .......... \\
\hline Examinador(a): & Assinatura: \\
\hline & Nome: .......... \\
\hline & Instituição: ................ \\
\hline Examinador(a): & Assinatura: .. \\
\hline & Nome: ............... \\
\hline & 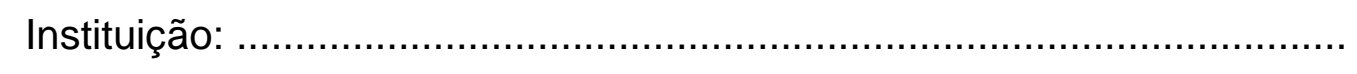 \\
\hline Presidente: & Assinatura: \\
\hline & Nome: ............. \\
\hline & Instituição: ......... \\
\hline
\end{tabular}




\section{PARFCER 762/CEP}

Prczado Senhor,

Atendendo sua solicitação, a Comissão de Ética em Pesquisas com Seres Humanus do ICB, em sua $72^{\text {a }}$ reunião realizada em 06.02 .07 , analisou o projeto de sua responsabilidade intitulado: "Caracterização biológica e molecular de recombinantes naturais de $\mathrm{HIV-1}$ ".

Informo a V.Sa. que, após análise e discussão, o referido projeto foi aprovado por esta Comissão.

Lembramos que cabe ao pesquisador elaborar e apresentar a este Comitê, relatórios anuais (parciais ou final), de acordo com a resolução 196/o6 do Conselho Nacional da Saúde, item IX.2 letra c.

O primeiro relatório deverá ser encaminhado à Secretaria deste CEP em 06 de fevereiro de 2008 .

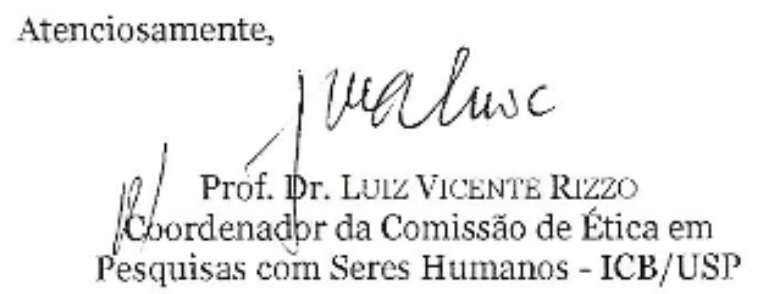

Ilmo. Sr.

FERNANDO LUCAS DE MELO

Departamento de Microbiologia

Instituto de Ciências Biomédicas -USP

Comissâo de Ética em Pesquisa com Seres Humanos do Instituto de Ciẻncias Biomédicas / USP Aprovada pela Comissão Nacional de Ética em Pesquiser - CONEP, em 10 de fevereiro de 1998 


\section{AGRADECIMENTOS}

À CAPES, pela bolsa de doutoramento concedida no período de 2006-2007.

À FAPESP, pela bolsa de doutoramento concedida no período de 2007-2010 (07/01554-9) e pelo auxílio financeiro para execução do projeto (00/04205-6).

Ao Hospital Nove de Julho pela doação dos concentrados de leucócitos.

Ao AIDS Research and Reference Reagent Program, Division of AIDS, NIAID, NIH, pela doação de reagents e células, importantes na realização deste trabalho.

Aos inúmeros pacientes que concordaram em participar deste estudo.

Aos pesquisadores envolvidos no projeto VGDN. Principalmente a Dra Leda Jamal.

Aos técnicos do Departamento de Microbiologia, particularmente ao Valdino de Souza técnico do Laboratório de Evolução Molecular e Bioinformática.

Aos pós-graduandos e docentes do Departamento de Microbiologia do ICB da USP, pelas ideias e momentos compartilhados.

Às meninas do Departamento de Genética e Biologia Evolutiva do IB da USP, Joana Mello, Ana Fraga, Kelly Nunes e Sabine Eggers, pelas discussões enriquecedoras.

Ao Prof. Paolo Zanotto, por ter permitido que eu fizesse parte de um grupo de trabalho estimulante e competente. Agradeço também pelos inúmeros ensinamentos que auxiliaram minha formação profissional e pessoal.

Aos amigos do LEMB: Atila Iamarino, Marco Corsini e Marco Motoki, que me ajudaram a construir este trabalho. Caio Freire, Danielle Ferreira, Juliana Bloch, Julian Villabona e Tatiana Torres que me proporcionaram bons momentos no laboratório. Juliana Velasco (jubis), um modelo utópico de conduta organizacional laboratorial e por compartilhar seu arroz, feijão e lingüiça. Ana Vitória Botelho (ana v), por ser como ela é e por ter me trazido bebidas lácteas de morango. Carla Braconi (ac), por ter me mantido na linha (não sei definir direito o que ela faz), e por ter me alimentado durante os anos do doutorado. O tempero pré-casamento era melhor (obrigado Mary Jo). Camila Romano (camis), que poucas vezes me trouxe comida, mas foi minha grande colaboradora. Muitas coisas não teriam sido possíveis sem vocês. 
A todos os meus amigos, eu poderia listá-los, mas agora estou com preguiça... pois como sabem eu deixo tudo pra última hora. Preciso aprender a medir a intensidade das coisas e não desaparecer.

À minha família, que entendeu minha ausência e o significado dessa tal de tese.

À menina com uma flor, Leia Cecília, minha melhor conquista, e que apesar dos momentos distantes não se esqueceu de que eu voltaria depressa, assim que a noite acabasse e que este tempo passasse. 
"... when the mind is strongly excited, we might expect that it would instantly affect in a direct manner the heart; and this is universally acknowledged (...) when the heart is affected it reacts on the brain; and the state of the brain again reacts through the pneumo-gastric nerve on the heart; so that under any excitement there will be much mutual action and reaction between these, the two most important organs of the body..."

The Expression of the Emotions in Man and Animals

Charles Darwin

“...is responsible for such varied tasks as heart rate, gastrointestinal peristalsis, sweating, and quite a few muscle movements in the mouth, including speech..." 


\section{RESUMO}

MELO, F. L. Caracterização biológica e molecular de recombinantes naturais de HIV-1. 2011. 139 f. Tese (Doutorado em Microbiologia) - Instituto de Ciências Biomédicas, Universidade de São Paulo, São Paulo, 2011.

A recombinação durante a transcrição reversa é um fator importante no aumento da diversidade genética e adaptação do HIV-1, permitindo que mutações vantajosas presentes em diferentes linhagens sejam combinadas em um mesmo genoma. No Brasil, vários recombinantes foram descritos e seis formas recombinantes circulantes (CRFs) já foram identificados, demonstrando a relevância destes recombinantes na epidemia brasileira. Portanto, um dos objetivos desta tese foi analisar os dados gerados pela Rede de Diversidade Genética Viral (VGDN) (sequências parciais de gag, pol e env), a fim de identificar recombinantes inter-subtipos de HIV-1 e avaliar a frequência e distribuição geográfica destes vírus. Utilizando diferentes técnicas foram identificados 152/1083 pacientes portadores de recombinantes $\mathrm{BF}$. A frequência destes recombinantes foi maior em cidades como São Vicente $(30 \%)$ e Sorocaba $(22,6 \%)$, sendo que os recombinantes circulantes em São Vicente foram geralmente relacionados às CRF28 e CRF29, enquanto que os vírus presentes na região de Sorocaba comumente apresentam um envelope subtipo F1, independente do subtipo nos demais genes. Além disso, o gene da integrase de 159 pacientes foi amplificado e sequenciado. A análise deste gene revelou mais 10 pacientes infectados com recombinantes $\mathrm{BF}$ e nenhuma mutação de resistência primária aos inibidores da integrase foi encontrada. $\mathrm{O}$ segundo objetivo foi isolar e caracterizar recombinantes $\mathrm{BF}$ in vitro. $\mathrm{O}$ isolamento viral foi realizado por co-cultivo e ao final foram obtidos 10 isolados primários. O sequenciamento do genoma quase completo desses dez isolados primários revelou que três isolados primários pertencem ao grupo da CRF28_BF, três ao grupo da CRF29_BF e quatro foram classificados como formas recombinantes únicas (URFs). Ainda, o uso de correceptores desses isolados foi avaliado in vitro em ensaios com as células GHOST(3), e revelou três duplo-trópicos (X4/R5) vírus, quatro CXCR4 (X4) e três isolados utilizaram apenas CCR5 (R5). Em suma, uma alta frequência de URFs foi encontrada em algumas cidades do Estado de São Paulo, e também foi desenvolvido e caracterizado um painel de isolados primários representando as CRF28_BF, CRF29_BF e algumas URFs.

Palavras-chaves: HIV. Genoma. Recombinação Genética. Evolução Molecular. Filogenia. Diversidade Genética. 


\section{ABSTRACT}

MELO, F. L. Biological and molecular characterization of HIV-1 natural recombinants. 2011. 139 p. Ph. D. Thesis (Microbiology) - Instituto de Ciências Biomédicas, Universidade de São Paulo, São Paulo, 2011.

Recombination during reverse transcription is an important factor promoting HIV-1 diversity and adaptive change, allowing advantageous mutations arising on different genomes to undergo linkage in the same progeny recombinant genome more frequently than what would be expected under random mutation alone. In Brazil, several recombinant viruses were reported, and six circulating recombinant forms (CRFs) have already been identified. Therefore, the first objective of this Thesis was to analyze the data generated by the Viral Genetic Diversity Network (VGDN) (gag, pol and env partial sequences), in order to identify HIV-1 intersubtype recombinants and evaluate the frequency and geographical distribution of these viruses. Using different techniques we identified 152/1083 patients harboring BF recombinants. The frequency of these recombinants was higher in cities like São Vicente $(30 \%)$ and Sorocaba (22.6 \%). The recombinant viruses circulating in São Vicente were generally related to CRF28 and CRF29, while those viruses circulating in Sorocaba commonly presented an envelope region of subtype F1, irrespective the subtype composition on the remaining genes. Additionally, the integrase gene of HIV-1 from 159 patients was further amplified and sequenced. The analysis of this viral gene revealed ten more patients infected with $\mathrm{BF}$ recombinants and no primary mutations related to integrase inhibitor resistance were found. The second objective was to isolate and characterize BF recombinants in vitro, which resulted in ten primary HIV-1 isolates. The near full-length genomes of these ten primary isolates revealed that three were related to CRF28_BF, three to CRF29_BF and four were unique recombinant forms (URFs), according to their breakpoints profile determined with the jpHMM program. Additionally, the coreceptor usage of these isolate was investigated in vitro using GHOST assays, which revealed three dual-tropic (X4/R5) viruses, four CXCR4 (X4) viruses and three CCR5 (R5) viruses. In sum, we report a high frequency of URFs in some cities of São Paulo State, and also developed a well-characterized panel of viruses representing CRF28_BF, CRF29_BF and URFs.

Key-words: HIV. Genome. Genetic Recombination. Molecular Evolution. Phylogeny. Genetic Diversity. 


\section{SUMÁRIO}

1 INTRODUÇÃ

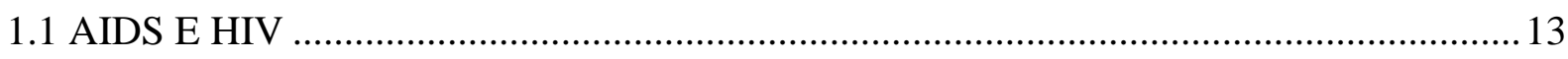

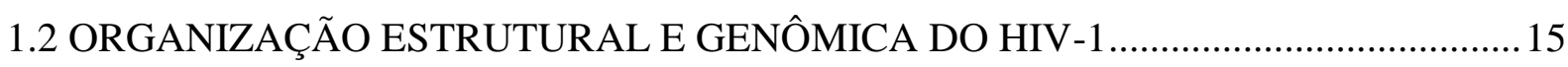

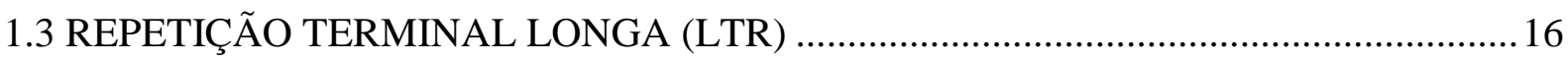

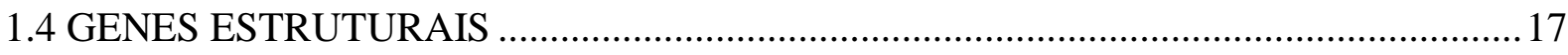

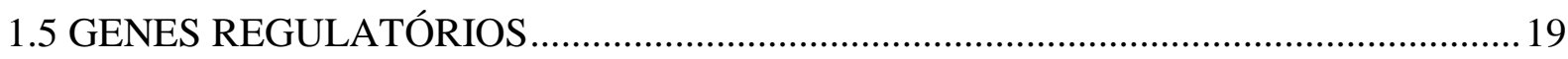

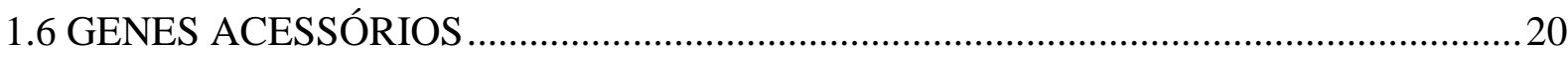

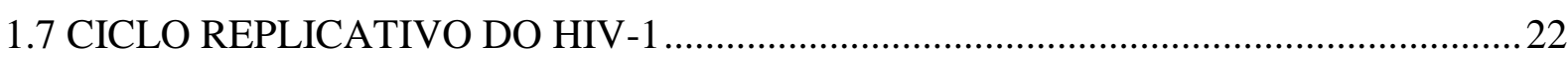

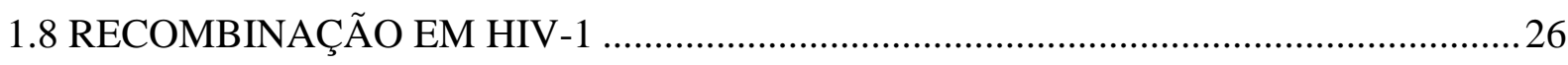

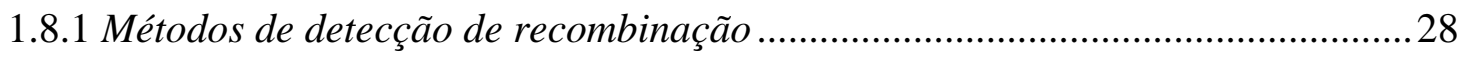

1.9 A EPIDEMIA BRASILEIRA E AS FORMAS RECOMBINANTES................................32

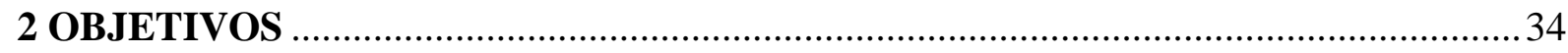

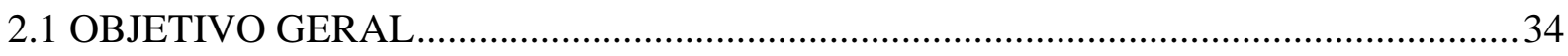

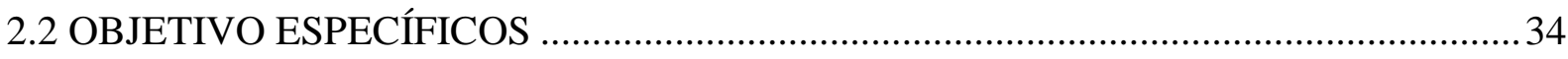

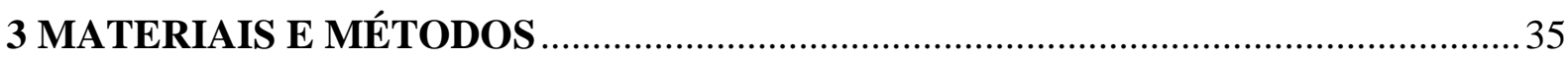

3.1 CARACTERIZAÇÃO DAS SEQUÊNCIAS DE HIV-1 DO PROJETO VGDN.................35

3.1.1 Alinhamento, análise de recombinação e reconstrução filogenética ....................36

3.1.2 Caracterização do gene da integrase .................................................................. 36

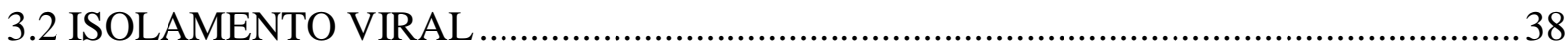

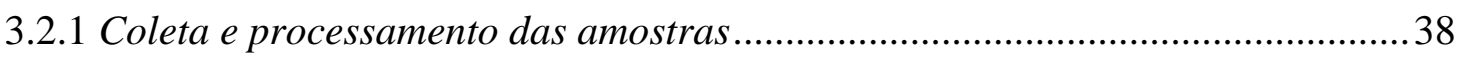

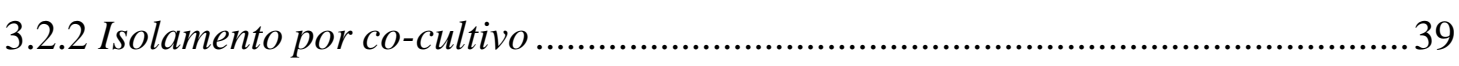

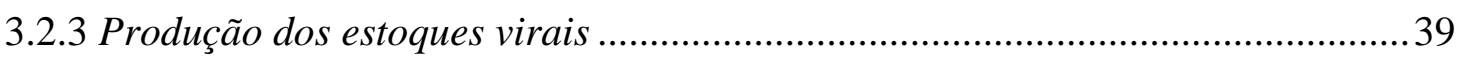

3.3 CARACTERIZAÇÃO GENÔMICA DOS RECOMBINANTES …………………….......40

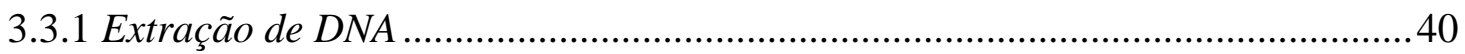

3.3.2 nested-PCR para amplificação do genoma de HIV-1 ......................................... 40

3.3.3 Reação de sequenciamento ................................................................................. 43

3.4 CARACTERIZAÇÃO DO USO DE CORRECEPTORES ………………………….....4

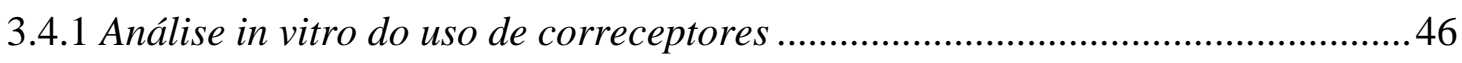

3.4.2 Análise in silico do uso de correceptores ............................................................. 47

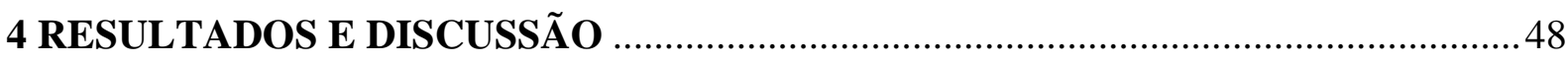

4.1 CARACTERIZAÇÃO DAS AMOSTRAS SEQUENCIADAS NO PROJETO VGDN ...48 
4.1.1 Frequência dos subtipos e distribuição espacial.................................................48

4.1.2 Perfil de recombinação dos genes gag, pol e env .............................................56

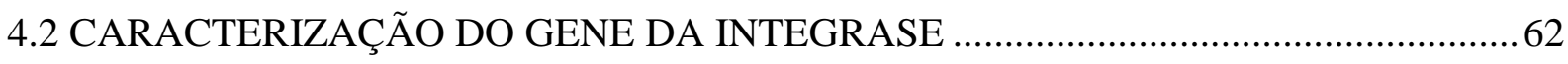

4.2.1 Perfil de resistência genotípica ao raltegravir...................................................67

4.3 ISOLAMENTO E CARACTERIZAÇÃO DE RECOMBINANTES BF ..........................69

4.3.1 Isolamento viral, caracterização genômica e uso de correceptores .....................69

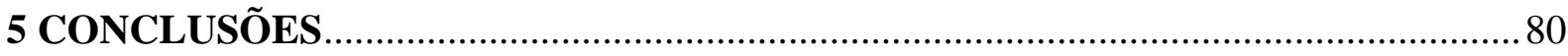

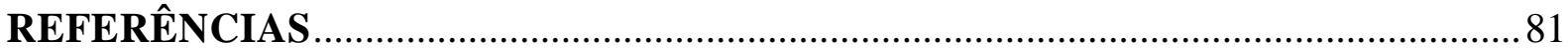

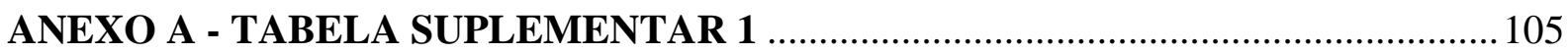

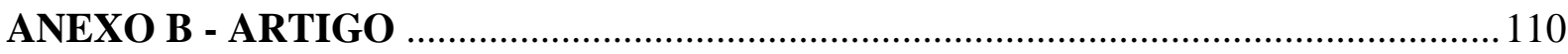

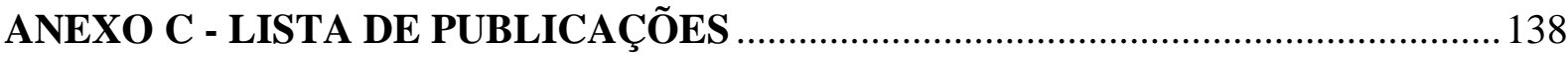




\section{INTRODUÇÃO}

\subsection{AIDS E HIV}

No início da década de 80 o HIV-1 (BARRE-SINOUSSI et al., 1983; GALLO et al., 1983) e o HIV-2 (CLAVEL et al., 1986) foram descritos pela primeira vez como os agentes etiológicos da síndrome da imunodeficiência adquirida (AIDS) (GOTTLIEB et al., 1981; MASUR et al., 1981). Três décadas após esta descoberta, mais de 20 milhões de pessoas já morreram em decorrência da AIDS e outras 33 milhões estão infectadas por HIV (JOINT UNITED NATIONS PROGRAM ON HIV/AIDS/WORLD HEALTH ORGANIZATION, 2010).

O HIV-1 é o responsável pela maioria infecções em todo o mundo, enquanto que as infecções por HIV-2 concentram-se principalmente na África Ocidental (REEVES e DOMS, 2002; TAYLOR et al., 2008). Ambos pertencem à família Retroviridae, genêro Lentivirus (COFFIN; HUGHES; VARMUS, 1997), e originaram-se a partir de diferentes lentivírus de primatas não-humanos africanos (HIRSCH et al., 1989; GAO et al., 1999; DAMOND et al., 2004; SHARP e HAHN, 2010).

O HIV-1 está subdividido em quatro grupos: $\mathrm{M}$ (main), $\mathrm{N}$ (new), O (outlier) e o recentemente descrito grupo $\mathrm{P}$ (putative), cada um proveniente de diferentes eventos de transmissão zoonótica (Figura 1) (ROBERTSON et al., 2000; PLANTIER et al., 2009; SHARP e HAHN, 2010). Os grupos O e N estão restritos a alguns países da África Central Ocidental (GURTLER et al., 1994; SIMON et al., 1998; VALLARI et al., 2010) e são responsáveis por menos de 5\% das infecções em todo o mundo (LAL; CHAKRABARTI; YANG, 2005). Até o momento o grupo $\mathrm{P}$ foi encontrado em apenas uma paciente camaronesa (PLANTIER et al., 2009). O grupo M é o mais prevalente e pode ser dividido em diferentes subtipos (A-D, F, H, J e K) (ROBERTSON et al., 2000). Os subtipos F e A podem ainda ser subdivididos nos sub-subtipos F1 e F2 (TRIQUES et al., 1999) e A1-A4 (GAO et al., 2001; MELONI et al., 2004; NJAI et al., 2006). Além dos subtipos descritos acima, 49 formas recombinantes circulantes (CRFs) foram descritas até o final de 2010 (http://www.hiv.lanl.gov/content/hiv-db/CRFs/CRFs.html).

Apesar do aumento no número de sequências disponíveis para os diferentes subtipos e uma maior disponibilidade de genomas completos, a classificação de HIV-1 em subtipos/subsubtipos e CRFs ainda é uma questão complexa e continuamente sofre alterações, como por 
exemplo, a reclassificação do subtipo $\mathrm{G}$ como uma forma recombinante (ABECASIS et al., 2007). Ademais, a diversidade genética em HIV-1 é um dos maiores obstáculos para a implementação de estratégias vacinais, uma vez que tanto a resposta imunológica humoral quanto a celular aparentemente não conferem proteção contra eventos de superinfecção (JOST et al., 2002; RAMOS et al., 2002; FANG et al., 2004; STEAIN et al., 2004; PIANTADOSI et al., 2007).

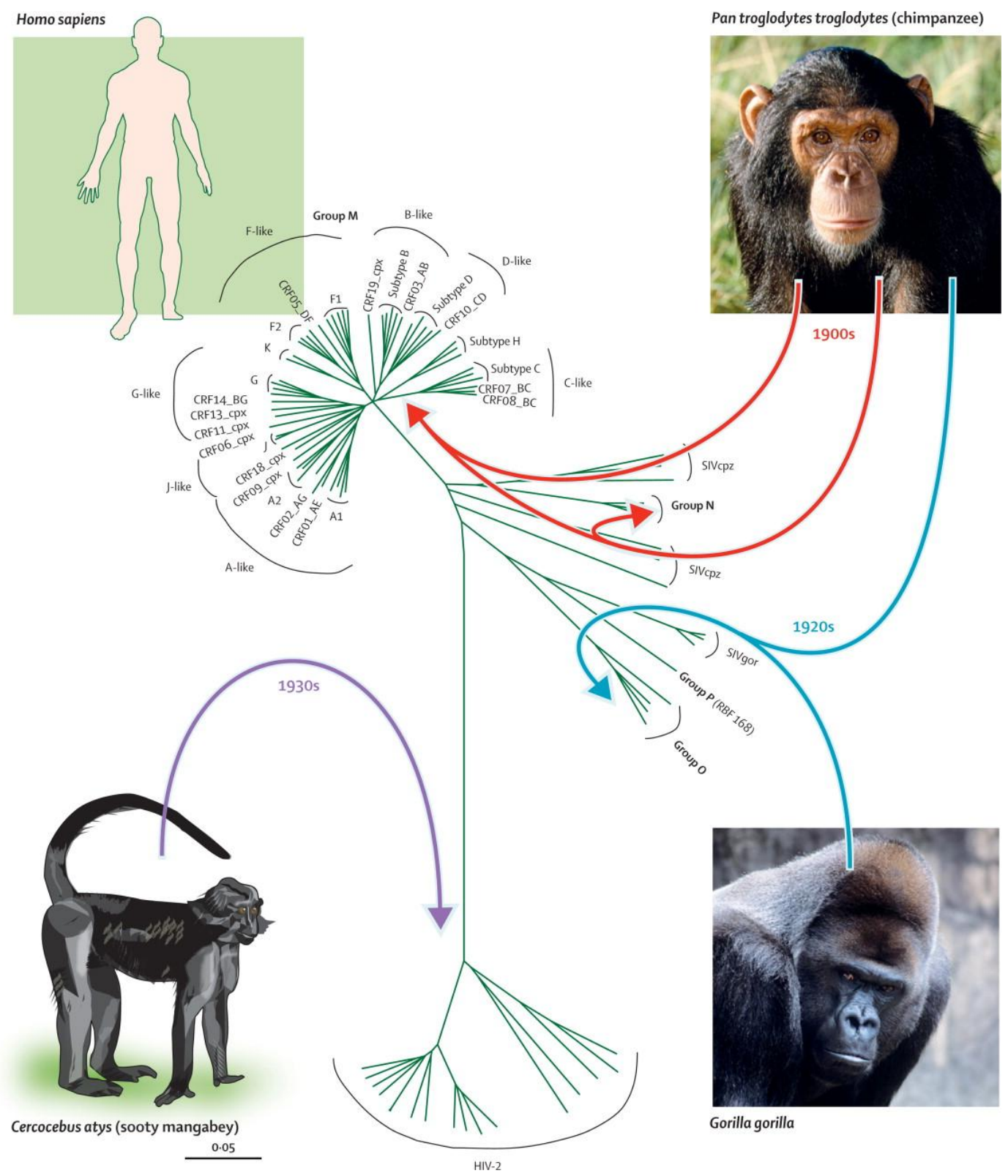

Figura 1- Relações filogenéticas entre SIVs (simian imunodeficiency vírus) e HIV. É importante observar os diferentes eventos de transmissão entre espécies que deram origem aos grupos de HIV-1 e HIV-2.

FONTE: Tebit e Arts (2011), com permissão. 


\subsection{ORGANIZAÇÃO ESTRUTURAL E GENÔMICA DO HIV-1}

O HIV-1 é um vírus envelopado com cerca de $100 \mathrm{~nm}$ de diâmetro, seu genoma é constituído por duas moléculas idênticas de RNA fita simples de polaridade positiva com aproximadamente $9.2 \mathrm{~kb}$ (Figura 2). No envelope viral lipoproteico estão inseridas as glicoproteínas virais. Na porção interna do envelope observa-se a proteína da matriz que envolve um capsídeo cônico, onde estão contidas as duas fitas de RNA e algumas das enzimas necessárias durante o ciclo replicativo viral (protease, transcriptase reversa e integrase). As moléculas de RNA genômico viral encontram-se associadas aos monômeros da proteína do nucleocapsídeo (COFFIN; HUGHES; VARMUS, 1997).

O genoma viral apresenta três genes principais: (i) gag, que codifica as proteínas estruturais internas; (ii) pol, que codifica a protease, a transcriptase reversa e a integrase; (iii) env, que codifica as glicoproteínas do envelope, gp120 e gp41 (Figura 3). Como todo retrovírus complexo, o HIV-1 possui genes reguladores (tat, rev) e genes acessórios (nef, vpr, vif e vpu), cujos transcritos são gerados após o processamento total (multiply spliced transcript) ou parcial (single spliced transcript) do RNAm longo (Figura 3). As regiões codificadoras no provírus são flanqueadas por repetições terminais longas (long terminal repeats, LTR) (Figura 3) (COFFIN; HUGHES; VARMUS, 1997; FRANKEL e YOUNG, 1998).

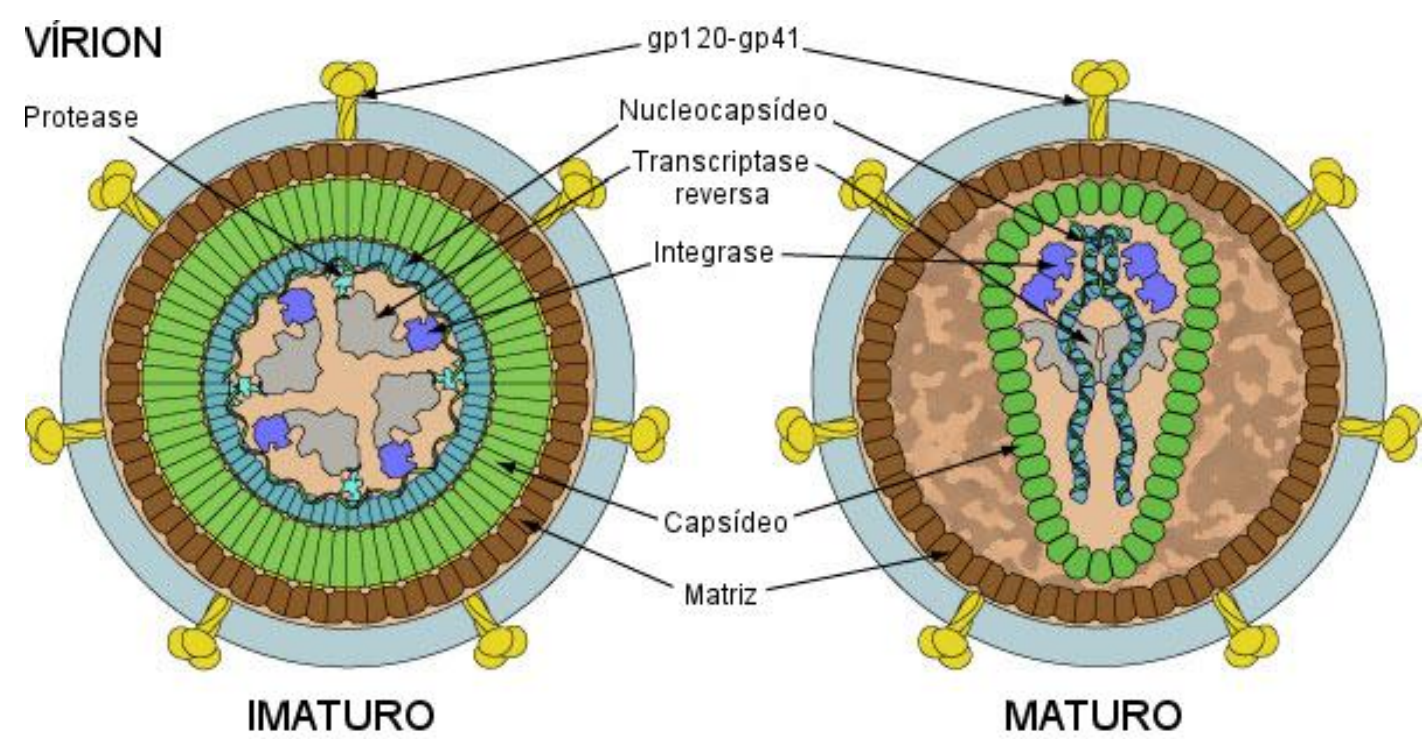

Figura 2- Representação esquemática da organização do vírion imaturo e maturo de HIV-1. FONTE: Adaptado de Swiss Institute of Bioinformatics ([2011]), com permissão. 


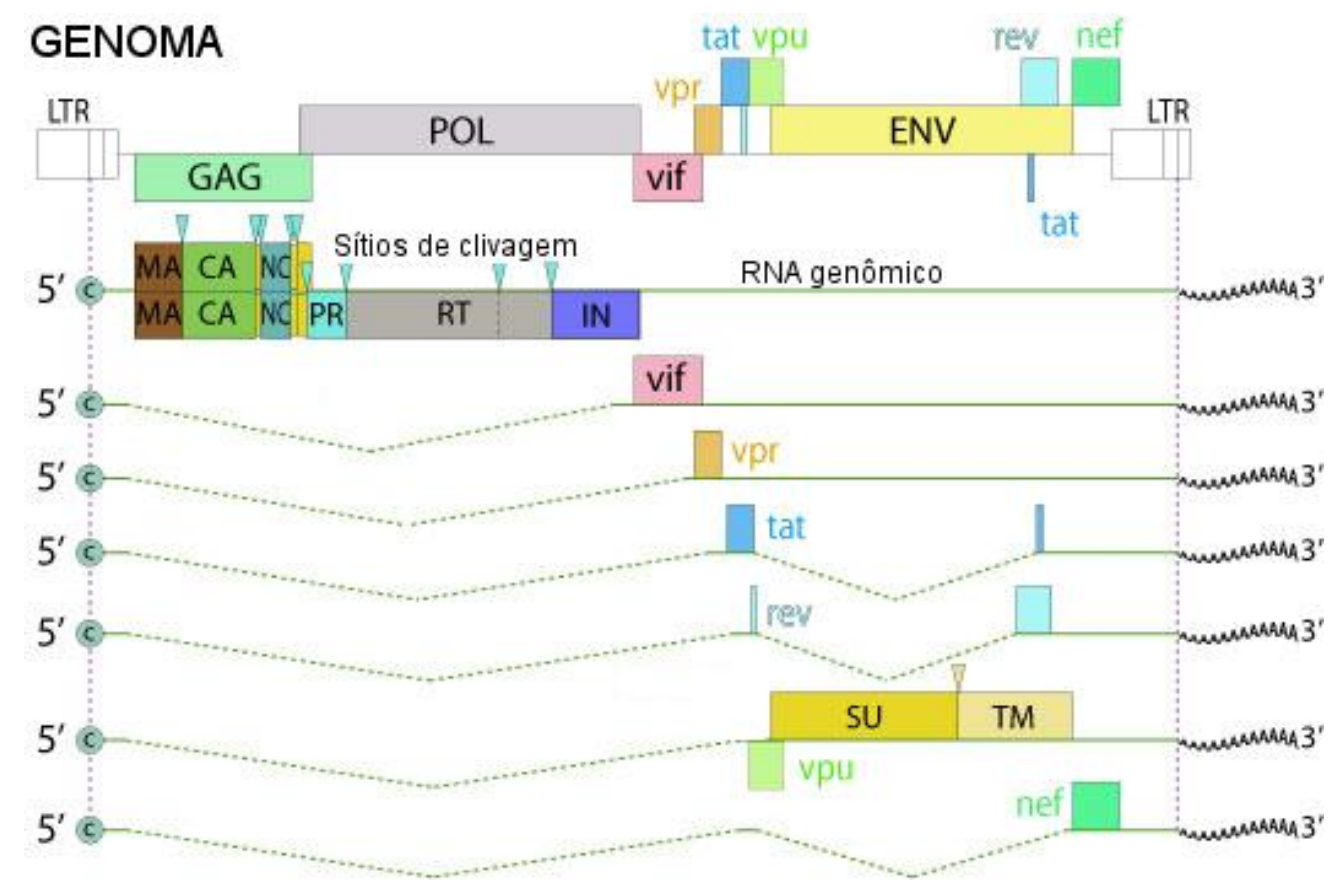

Figura 3- Organização genômica do DNA proviral de HIV-1 e transcritos gerados durante o processo replicativo.

FONTE: Adaptado de Swiss Institute of Bioinformatics ([2011]), com permissão.

\subsection{REPETIÇÃO TERMINAL LONGA (LTR)}

Como descrito anteriormente, o genoma proviral de HIV-1 é flanqueado por duas LTRs idênticas, cujo processo de duplicação e formação da segunda LTR será descrito mais adiante. Basicamente, as LTRs possuem todos os sinais para o início e o término da transcrição, além de serem importantes na transcrição reversa e na integração viral. Cada LTR possui cerca de 640 nucleotídeos subdivididos em três regiões funcionais distintas: U3 (extremidade 3' única), R (região repetida) e U5 (extremidade 5' única) (KREBS et al., 2001; RAMIREZ DE ARELLANO et al., 2006) (Figura 4). Na região U3 existe uma sequência TATAA box e um sítio para o fator de transcrição Sp1 (specificity protein 1), ambas necessárias para o início da transcrição pela RNA Polimerase II, a montante estão presentes sítios de ligação para NF-אB (nuclear factor kappa $B$ ) e outros fatores de transcrição, além de um elemento regulador negativo (NRE: negative regulatory element). Na região $\mathrm{R}$ está localizado o elemento responsivo da transativação (TAR), sítio de ligação da proteína Tat produzida pelo genoma viral. A região U5 possui sítios de ligação para fatores de transcrição como AP-1, AP-3 (activator protein) e Sp1. A transcrição começa no início da região R da LTR 5' e termina após um sinal de poliadenilação no final da região R da LTR 3' (KREBS et al., 2001; RAMIREZ DE ARELLANO et al., 2006). 

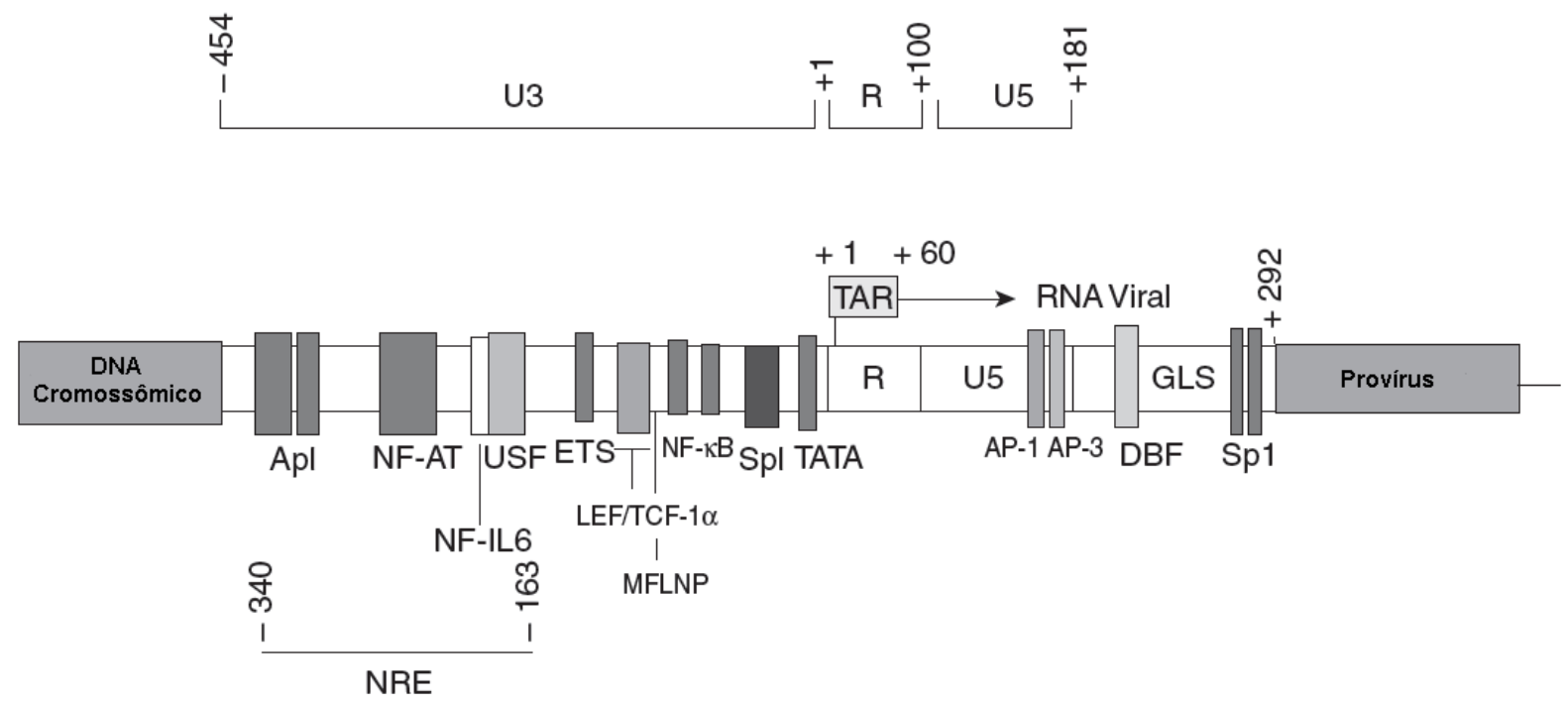

Figura 4- Representação esquemática da LTR 5' de HIV-1. Alguns dos sítios de ligação para fatores de transcrição celulares representado são: NF-AT (nuclear factor of activated T-cell), NFIL6 (IL-1 inducible nuclear factor), USF (upstream stimulatory factor), ETS (E-twenty six), LEF (lymphocyte enhance factor) e TCF-1 $\alpha$ (T-cell factor alpha). As coordenadas estão de acordo com o sítio de início da transcrição.

FONTE: Adaptado de Ramirez de Arellano et al. (2006), com permissão.

\subsection{GENES ESTRUTURAIS}

O gene gag codifica a poliproteína p55 Gag $(55 \mathrm{kDa})$, que no momento da maturação viral é clivada pela protease viral em: p17 (MA; matriz), p24 (CA; capsídeo), p7 (NC; nucleocapsídeo), p6 e em dois peptídeos curtos denominados SP1e SP2 (short linker peptide) (COFFIN; HUGHES; VARMUS, 1997; FRANKEL e YOUNG, 1998; GÖTTLINGER, 2001). A porção N-terminal da p55 Gag é constituída pela proteína p17 (MA) e associa-se à membrana plasmática após sofrer miristoilação (BRYANT e RATNER, 1990). A proteína p17 ainda interage com as glicoproteínas virais durante o processo de montagem da partícula na membrana plasmática (DORFMAN et al., 1994). A proteína p24 é o monômero que forma o capsídeo viral e é responsável pelo encapsidamento da proteína celular LysRS (lysyl-tRNA synthetase), responsável pela aminoacilação e encapsidamento do tRNA ${ }^{\text {lys }}$ que será utilizado como iniciador durante o processo de transcrição reversa (MASCARENHAS e MUSIERFORSYTH, 2009). Por sua vez, a proteína p7 possui dois domínios de dedo de zinco que reconhecem o sinal de empacotamento do genoma viral (HARRISON e LEVER, 1992), permitindo o empacotamento de duas cópias do RNA genômico pela p55 Gag (SCHWARTZ; FIORE; PANGANIBAN, 1997). Esta proteína é capaz de se ligar inespecificamente a ácidos 
nucleicos e é fundamental em diferentes fases do processo replicativo viral (GÖTTLINGER, 2001). Por fim, a proteína p6 (porção C-terminal da p55 Gag) possui um motivo proteico conservado (Pro-Thr/Ser-Ala-Pro) essencial no processo de brotamento viral (GOTTLINGER et al., 1991; HUANG et al., 1995). Esta proteína é encontrada apenas em lentivírus de primatas, entretanto o motivo conservado está presente em diferentes vírus envelopados e é responsável pelo recrutamento de proteínas relacionadas com a maquinaria de transporte dos corpos multivesiculares (VON SCHWEDLER et al., 2003; DUSSUPT et al., 2009). Além disso, a p6 é responsável pelo encapsidamento da proteína viral Vpr durante o processo de montagem (BACHAND et al., 1999).

Como descrito anteriormente, o gene pol codifica as enzimas protease, transcriptase reversa e integrase. Essas enzimas são sintetizadas como uma poliproteína denominada p160 Gag-Pro-Pol (160 kDa) traduzida a partir do mesmo RNAm que dá origem a p55 Gag após uma mudança na fase de leitura ribossomal, que ocorre de 5\%-10\% das vezes e é favorecida por elementos estruturais presentes nesta região (JACKS et al., 1988; WILSON et al., 1988; WATTS et al., 2009). Assim como a p55 Gag, a p160 Gag-Pro-Pol associa-se à membrana plasmática na região de montagem. Durante o brotamento e início do processo de maturação viral a p160 Gag-Pro-Pol é clivada de forma autocatalítica resultando na forma madura da protease viral, um homodímero da família das aspartil-proteases, que inicia o processamento proteolítico de p55 Gag e p160 Gag-Pro-Pol (PEARL e TAYLOR, 1987; LOUIS et al., 1994; HILL; TACHEDJIAN; MAK, 2005).

A transcriptase reversa (RT) é um heterodímero constituído de subunidades assimétricas de $66 \mathrm{kDa}$ (p66) e $51 \mathrm{kDa}$ (p51), possui atividade de DNA-polimerase RNA e DNA-dependente, além de atividade de RNase H, ambas localizadas na subunidade p66, e a subunidade p51 possui apenas função estrutural (JOHNSON et al., 1986; LE GRICE et al., 1991; HILL; TACHEDJIAN; MAK, 2005). A porção C-terminal da p160 Gag-Pro-Pol dá origem à integrase com $32 \mathrm{kDa}$, a qual é responsável pelo processamento das extremidade 3'do DNA viral e posterior integração no genoma hospedeiro. Esta enzima possui três domínios funcionais (N-terminal, catalítico e C-terminal) e pertence à superfamília das polinucleotidil transferases (DYDA et al., 1994; ANDRAKE e SKALKA, 1996). Apesar da estrutura da integrase de HIV-1 ainda não ter sido completamente elucidada, a estrutura de cada um dos seus domínios foi determinada individualmente (DYDA et al., 1994; LODI et al., 1995; CAI et al., 1997). Funcionalmente a integrase forma um tetrâmero associado às duas extremidades do DNA viral (LI et al., 2006), e cada um dos três domínios participa na interação DNA-proteína e proteína-proteína, como demonstrado recentemente pela 
determinação da estrutura completa da integrase de foamy virus associada ao DNA viral (HARE et al., 2010).

O gene env codifica as glicoproteínas do envelope, que também são sintetizadas a partir de um mesmo RNAm como uma poliproteína denominada gp160 (160 kDa). Esta poliproteína é traduzida no retículo endoplasmático e direcionada ao complexo de Golgi, onde é clivada e glicosilada pela maquinaria celular, dando origem às proteínas gp120 e gp41 (WILLEY et al., 1988). A gp120 é responsável pela interação do vírion à molécula CD4 (LANDAU; WARTON; LITTMAN, 1988) e a um receptor de quimiocina (FENG et al., 1996; WU et al., 1996). Esta proteína é formada por cinco regiões variáveis (V1-V5), intercaladas por cinco regiões constantes (C1-C5), e está estruturalmente organizada em dois domínios conectados por uma folha $\beta$. A interação com a molécula de CD4 ocorre nesta região de conexão entre os dois domínios, enquanto que a ligação ao correceptor é mediada pela região V3 (KWONG et al., 1998). No envelope viral a gp120 encontra-se associada não covalentemente à gp41 formando heterodímeros que, por sua vez, se associam em trímeros (WYATT e SODROSKI, 1998). A gp41 apresenta um ectodomínio N-terminal responsável pela interação com a gp120 e pelo processo de fusão das membranas viral e celular (peptídeo de fusão), um domínio hidrofóbico transmembrana responsável por ancorar as proteínas do envelope na membrana viral, e um domínio C-terminal intra-vírion que interage com a proteína p17 da matriz (WYATT e SODROSKI, 1998).

\subsection{GENES REGULATÓRIOS}

Os genes reguladores de HIV-1 codificam as proteínas Tat (transcription transactivator) e Rev (regulator of expression of virion proteins), que atuam no processo de transcrição interagindo diretamente com o RNA viral (KARN et al., 1991). Ambas as proteínas são produzidas em grandes quantidades nos estágios iniciais da replicação viral a partir de RNAm totalmente processados (Figura 3) (ROBERT-GUROFF et al., 1990; KLOTMAN et al., 1991). A proteína Tat possui 14 kDa e apresenta domínios responsáveis pela transativação transcricional, um domínio de ligação ao RNA e de localização nuclear, e um domínio C-terminal necessário para a interação extracelular com a membrana de células não infectadas. Devido ao sinal de localização nuclear, essa proteína é transportada ao núcleo (RUBEN et al., 1989; ROBERT-GUROFF et al., 1990), onde se liga na região TAR do RNAm viral nascente (Figura 4) (BERKHOUT; SILVERMAN; JEANG, 1989). Tat é capaz de transativar a LTR de HIV, independente da ligação ao sítio TAR, através da ativação direta 


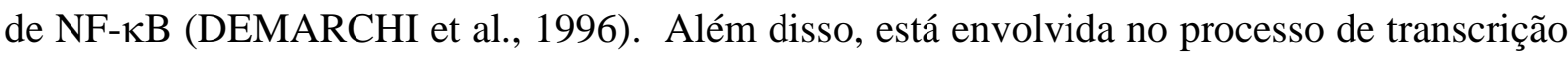
reversa (HARRICH et al., 1997) e na regulação negativa da expressão de alguns genes celulares envolvidos na resposta celular à infecção viral, como por exemplo, bcl-2 e MIP-1 $\alpha$ (SASTRY et al., 1996; SHARMA et al., 1996). Por fim, a proteína Rev é uma fosfoproteína nuclear cuja função é facilitar o transporte para o citoplasma de RNAm não processados ou parcialmente processados pela maquinaria celular de splicing, regulando assim todo o processo de síntese de proteínas virais (COCHRANE et al., 1989; POLLARD e MALIM, 1998).

\subsection{GENES ACESSÓRIOS}

Os genes acessórios codificam as proteínas Nef, Vif, Vpr e Vpu que, apesar de serem importantes fatores de virulência in vivo, não são essenciais para a replicação viral in vitro, (SEELAMGARI et al., 2004). A proteína Nef (negative regulatory factor) é produzida nas etapas iniciais do ciclo replicativo viral a partir de um RNAm totalmente processado (assim como Tat e Rev), possui 27 kDa e após sofrer miristoilação na porção N-terminal associa-se à membrana plasmática onde interage com diferentes proteínas (JERE et al., 2010). Nef é responsável pela diminuição da expressão dos receptores CD4, MHC-I, MHC-II, CXCR4 e CD28 na superfície das células infectadas (GARCIA e MILLER, 1991; AIKEN et al., 1994; SCHWARTZ et al., 1996; STUMPTNER-CUVELETTE et al., 2001; SWIGUT; SHOHDY; SKOWRONSKI, 2001; HRECKA et al., 2005). Além disso, aumenta a infectividade e replicação viral (MILLER et al., 1994), e é capaz de regular a ativação de linfócitos T (FOSTER e GARCIA, 2008).

O gene acessório vif codifica a proteína básica Vif (23 kDa) (viral infectivity factor), a qual é incorporada ao vírion durante o processo de montagem através da interação com o RNA viral e com a porção C-terminal da p55 Gag (LIU et al., 1995; KHAN et al., 2001). Apesar de não ser necessária na produção viral, ela é essencial para a infecciosidade viral (STREBEL et al., 1987), atuando na degradação das proteínas celulares citidina deaminases APOBEC3G/F (apolipoprotein B mRNA-editing enzyme catalytic polypeptide-like), que provocam hipermutação no genoma viral (SHEEHY; GADDIS; MALIM, 2003; WISSING; GALLOWAY; GREENE, 2010).

Assim como Vif, Vpr (viral protein $R$ ) é uma proteína básica (14 kDa) que interage com à região C-terminal de p55 Gag e é incorporada ao vírion (COHEN et al., 1990; PAXTON; CONNOR; LANDAU, 1993; BACHAND et al., 1999), está associada com a 
formação e transporte do complexo de pré-integração para o núcleo e com a fidelidade do processo de transcrição reversa (HEINZINGER et al., 1994; MANSKY, 1996; POPOV et al., 1998; LE ROUZIC e BENICHOU, 2005). Vpr também está relacionado com o bloqueio da mitose mantendo a célula infectada na fase G2 do ciclo celular (HE et al., 1995; JOWETT et al., 1995).

$\mathrm{O}$ último gene acessório codifica a fosfoproteína de membrana Vpu (16 kDa) (viral protein $U$ ) (STREBEL et al., 1989). Complementando uma das funções exercidas pela proteína Nef, a Vpu é capaz de interagir com as moléculas de CD4 presentes no retículo endoplasmático, encaminhando-as para a via de degradação proteolítica dependente de ubiquitina (WILLEY et al., 1992; MARGOTTIN et al., 1998). Por fim, a Vpu diminui a expressão da proteína antiviral teterina na membrana plasmática, permitindo assim o brotamento eficiente dos vírions (NEIL; ZANG; BIENIASZ, 2008; TOKAREV et al., 2009; DUBE et al., 2010; FITZPATRICK et al., 2010). A proteína teterina é um importante fator de restrição celular induzido por interferon presente na superfície de células infectadas, e inibe o brotamento de diversos vírus envelopados (JOUVENET et al., 2009; SAKUMA et al., 2009; TOKAREV et al., 2009; ARNAUD et al., 2010; FITZPATRICK et al., 2010; GROOM et al., 2010; MATTIUZZO; IVOL; TAKEUCHI, 2010). 


\subsection{CICLO REPLICATIVO DO HIV-1}

O ciclo replicativo do HIV-1 pode ser dividido em uma fase inicial, que se estende da adsorção à célula hospedeira até a integração do DNA viral, e em uma fase tardia, que tem início com a ativação transcricional do provírus latente e termina com o brotamento dos vírions (Figura 5) (COFFIN; HUGHES; VARMUS, 1997).
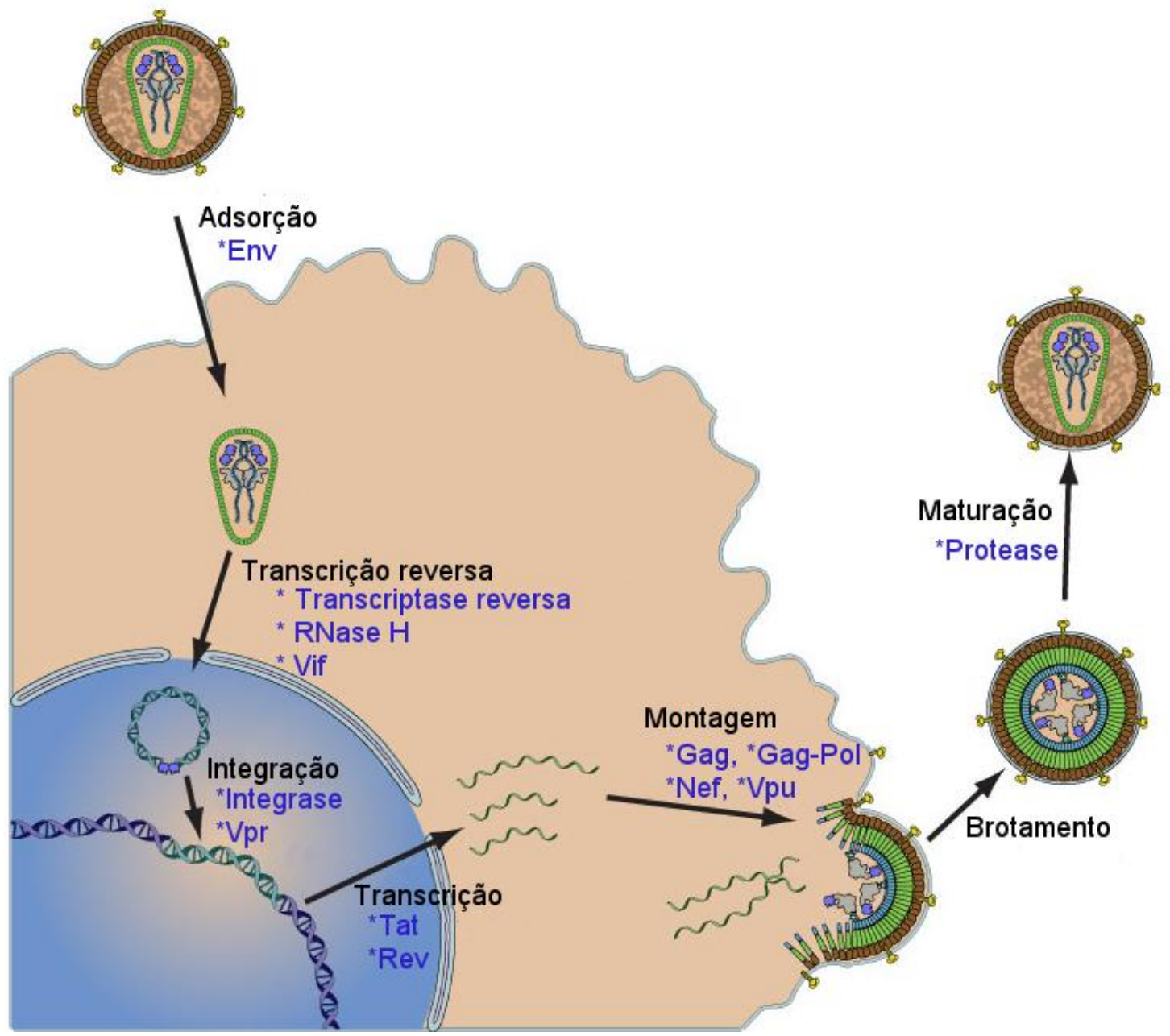

Figura 5- Ciclo replicativo do HIV. As proteínas virais envolvidas em cada etapa do ciclo replicativo estão destacadas em azul.

FONTE: Adaptado de Swiss Institute of Bioinformatics ([2011]), com permissão. 
A entrada do HIV-1 na célula hospedeira envolve a interação das glicoproteínas do envelope viral, descritas na seção 1.2.2, com um receptor primário (molécula de CD4) e com um correceptor (receptor de quimiocinas, CXCR4 ou CCR5) (BERGER; MURPHY; FARBER, 1999). A ligação à molécula de CD4 provoca mudanças conformacionais na gp120 que resultam numa maior exposição da região V3, favorecendo assim sua ligação ao correceptor. A interação da gp120 com os receptores celulares também provoca alterações conformacionais na gp41, as quais resultam na exposição e inserção do peptídeo de fusão na membrana celular, desencadeando o processo de fusão das membranas e formação de um poro por onde o capsídeo viral penetra no citoplasma da célula hospedeira (Figura 5) (DOMS e PEIPER, 1997; KWONG et al., 1998; BERGER; MURPHY; FARBER, 1999). Recentemente foi demonstrado que a entrada do HIV-1 na célula hospedeira ocorre principalmente via endocitose (Figura 6) (DAECKE et al., 2005; MIYAUCHI et al., 2009), entretanto a importância de cada um destes é uma questão ainda em aberto (PERMANYER; BALLANA; ESTE, 2010).

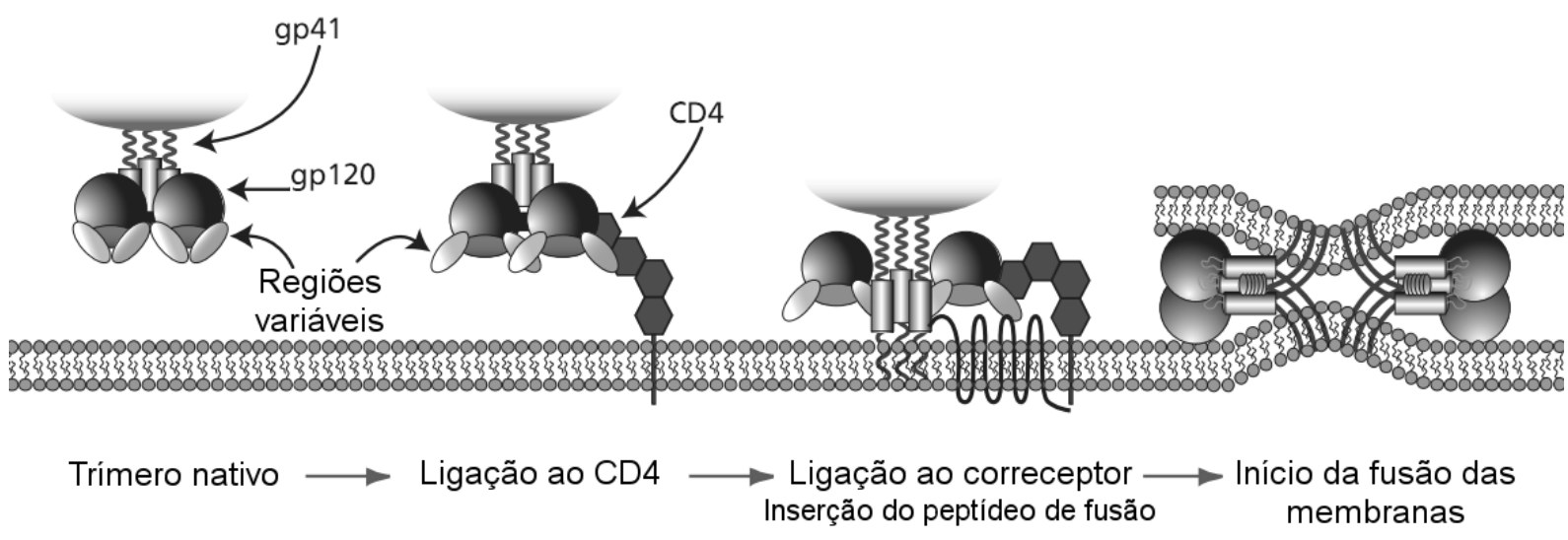

Figura 6- Processo de adsorção e fusão do víron à membrana plasmática da célula infectada. FONTE: Adaptado de Doms (2004), com permissão.

Após a fusão das membranas o nucleocapsídeo é liberado no citoplasma onde ocorre o processo de transcrição reversa do RNA viral (Figura 7) (COFFIN; HUGHES; VARMUS, 1997). Este processo tem início após a associação do iniciador tRNA ${ }^{\text {lys }}$ ao sítio PBS (primer binding site) na extremidade 5' do RNA viral (Figura 7-A), permitindo que a RT inicie a síntese da fita de DNA complementar à esta pequena região (LTR 5') (Figura 7-B). O domínio de RNase H da RT degrada o RNA usado como molde, permitindo que o segmento de DNA complementar recém-sintetizado associe-se à extremidade 3' do RNA viral (Figura 7C). Após completar a síntese da primeira fita de DNA, o RNA presente no híbrido RNADNA é degradado, exceto por uma região resistente à degradação, denominada PPT 
(polypurine tract) (Figura 7-D). Este RNA não degradado é utilizado pela RT como iniciador para a síntese da segunda fita de DNA, que se estende até o tRNA ${ }^{\text {lys }}$ presente na fita molde (Figura 7-D). Para que a síntese da segunda fita continue, a RT degrada o tRNA ${ }^{\text {lys }}$ e o DNA circulariza-se, de maneira que as regiões PBS das duas fitas se associem (Figura 7-E), permitindo a continuação da síntese da segunda fita DNA e completando a LTR da primeira fita de DNA (Figura 7-F). O resultado é uma molécula de DNA dupla fita flanqueada por duas LTRs.

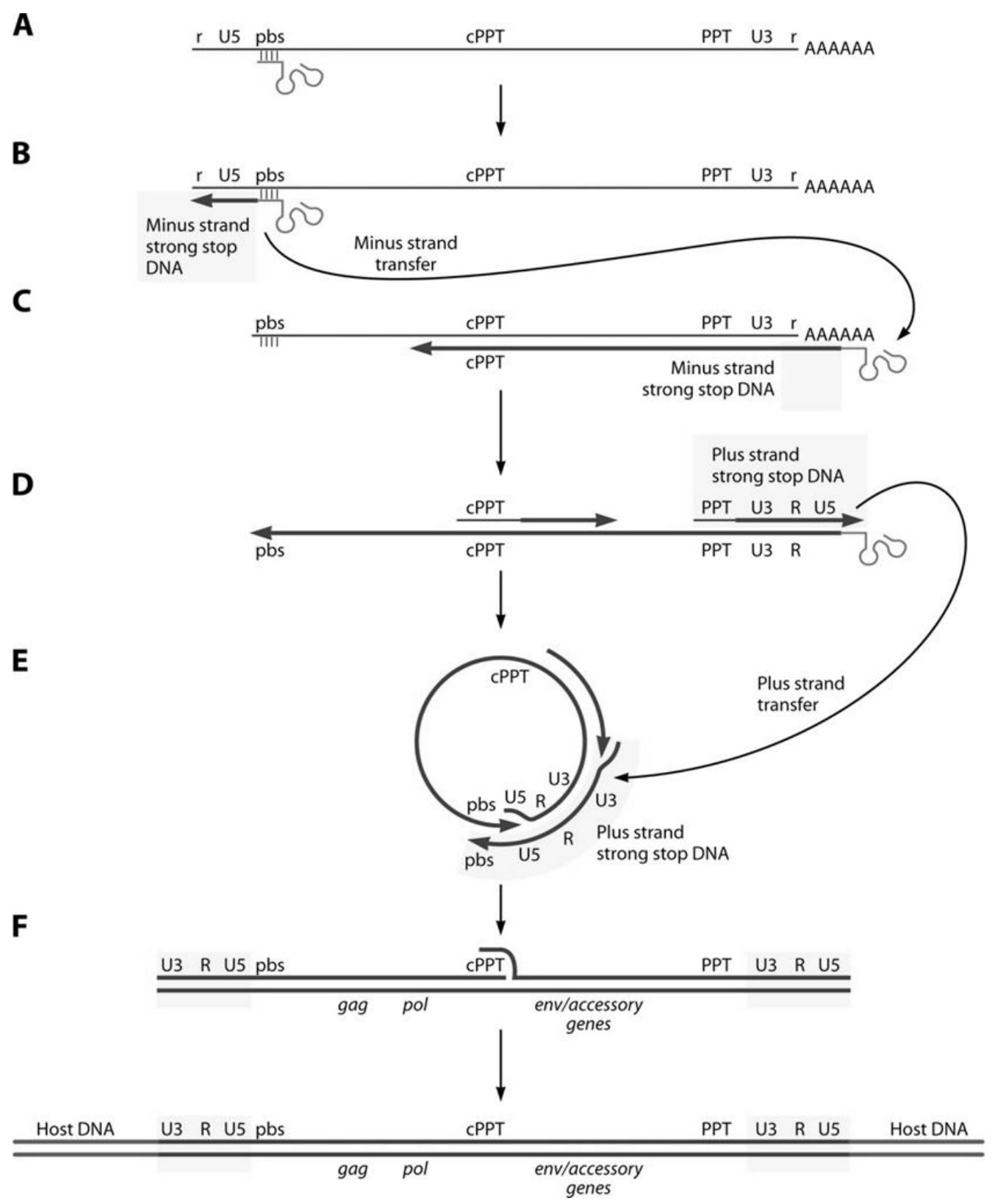

Figura 7- Esquema dos eventos da transcrição reversa em HIV-1. Explicação detalhada no texto acima.

FONTE: Onafuwa-Nuga e Telesnitsky (2009), com permissão. 
O momento exato em que se inicia o processo de desencapsidação ainda é desconhecido, entretanto evidências sugerem que o fim da transcrição reversa seja o fator desencadeador deste processo, uma vez que a desencapsidação prematura induzida pela proteína antiviral TRIM $\alpha$ diminui os níveis de transcrição reversa e de replicação viral (STREMLAU et al., 2006; ARHEL, 2010). O processo de desencapsidação é controlado pela ação de chaperonas celulares e proteínas virais (ARHEL, 2010; BRIONES; DOBARD; CHOW, 2010; MISUMI et al., 2010), dando origem ao complexo de pré-integração, no qual estão presentes a integrase, MA, NC, Vpr e algumas proteínas celulares, como por exemplo a LEDGF/p75 (Lens epithelium-derived growth factor) (FARNET e HASELTINE, 1991; BUKRINSKY et al., 1993; FARNET e BUSHMAN, 1997; MILLER; FARNET; BUSHMAN, 1997; LIN e ENGELMAN, 2003).

Assim que o complexo de pré-integração está formado, ele penetra pelo poro nuclear com auxílio de proteínas celulares denominadas importinas (LEVIN; LOYTER; BUKRINSKY, 2010). Uma vez dentro do núcleo o complexo de integração se liga ao DNA celular, permitindo que a integrase transfira o DNA viral para o genoma celular (HARE et al., 2010; MAERTENS; HARE; CHEREPANOV, 2010). O processo de integração do DNA viral no genoma hospedeiro ocorre com mais frequência em regiões transcricionalmente ativas, e é modulada pela interação da proteína LEDGF/p75 com a cromatina celular (SCHRÖDER et al., 2002; MITCHELL et al., 2004; CIUFFI et al., 2005).

A fase tardia do ciclo replicativo do HIV inicia-se somente após a ativação da célula hospedeira e depende da ligação de fatores de transcrição celulares à LTR 5' do provírus e posterior transcrição pela RNA polimerase II. Os RNAm produzidos nesta etapa são totalmente processados (Figura 3) e dão origem às proteínas Tat, Rev e Nef. Como descrito anteriormente, a proteína Tat liga-se na região TAR dos RNAs nascentes recrutando proteínas celulares responsáveis pela fosforilação da RNA polimerase II, aumentando assim sua processividade e favorecendo a elongação dos novos RNAm (BRIGATI et al., 2003). A partir deste momento a proteína Rev assume uma função crucial controlando a formação e transporte dos transcritos não processados (Gag, Gag-Pro-Pol e o RNA genômico) ou parcialmente processados (Vif, Vpr, Vpu e Env). Este controle é possível, pois nestes transcritos existe uma sequência denominada RRE (Rev response element) (MALIM et al., 1989), onde a proteína Rev se liga formando um complexo ribonucleoprotéico que é exportado para o citoplasma pela maquinaria celular de transporte nuclear (POLLARD e MALIM, 1998). Como descrito nas seções anteriores, as proteínas que irão formar a partícula 
viral e as moléculas de RNA genômico são encaminhadas para a região da membrana plasmática onde ocorre a montagem. Após o brotamento ocorre o processo de maturação da partícula viral, no qual as poliproteínas são clivadas pela protease viral e se rearranjam formando a partícula infecciosa (Figura 2).

\subsection{RECOMBINAÇÃO EM HIV-1}

Uma das características mais marcantes da biologia do HIV-1 é seu potencial de diversificação genética, tanto no paciente quanto na população. Grande parte desta variabilidade é gerada pela transcriptase reversa que apresenta alta taxa de incorporação de erros $\left(10^{-4} /\right.$ nucleotídeo/replicação) (PRESTON; POIESZ; LOEB, 1988; ROBERTS; BEBENEK; KUNKEL, 1988), além de um curto tempo de geração de 2.6 dias em média (HO; MOUDGIL; ALAM, 1989; WEI et al., 1995; PERELSON et al., 1996). Adicionalmente, eventos de recombinação durante a transcrição reversa representam um importante fator no aumento da variabilidade em HIV-1 (RAMIREZ et al., 2008; NEHER e LEITNER, 2010), permitindo que mutações vantajosas presentes em diferentes linhagens sejam combinadas num mesmo genoma (MOUTOUH; CORBEIL; RICHMAN, 1996; CHARPENTIER et al., 2006; NORA et al., 2007; STREECK et al., 2008; ARORA e DIXIT, 2009).

De fato, eventos de recombinação são bastante frequentes na replicação de HIV-1 (HU e TEMIN, 1990b) e a cada ciclo replicativo viral ocorrem cerca de 2-3 eventos de recombinação (JETZT et al., 2000; ZHUANG et al., 2002). A recombinação é um processo que ocorre em duas etapas. A primeira etapa tem início quando uma célula é infectada por dois vírus distintos, e moléculas de RNA de ambos os vírus são empacotadas em um mesmo nucleocapsídeo. A segunda etapa ocorre quando este vírion "heterozigoto" infecta outra célula, e durante a síntese do DNA viral a transcriptase reversa muda de uma fita de RNA molde para outra, gerando assim um provírus recombinante advindo das duas moléculas de RNA parentais (HU e TEMIN, 1990a; STUHLMANN e BERG, 1992; GALETTO e NEGRONI, 2005; ONAFUWA-NUGA e TELESNITSKY, 2009).

Todos os fatores necessários para que a recombinação ocorra já foram intensamente descritos, como por exemplo, indivíduos duplamente infectados com HIV-1 de diferentes grupos (HEYNDRICKX et al., 1996; TAKEHISA et al., 1997); de diferentes subtipos (PIENIAZEK et al., 1995; JANINI et al., 1996; JANINI et al., 1998); do mesmo subtipo (ZHU et al., 1995) e casos de re-infeção (RAMOS et al., 2002; FANG et al., 2004; 
PIANTADOSI et al., 2007). Além disso, a maioria das células infectadas pelo HIV-1 possui dois ou mais provírus integrados ao seu genoma (JUNG et al., 2002).

Este alto potencial recombinogênico é refletido na epidemia de HIV-1, e pelo menos $20 \%$ das formas circulantes em todo o mundo são recombinantes (OSMANOV et al., 2002). Este aumento no número de recombinantes identificados tem sido impulsionado pelo aumento na quantidade de genomas completos sequenciados, pois permite identificar eventos de recombinação em regiões do genoma não sequenciadas na maioria dos estudos de epidemiologia molecular.

Como descrito na seção 1.1, 49 CRFs (Circulating Recombinant Forms) já foram identificadas até o momento. Esta classificação em CRF empregada quando estes recombinantes apresentam um mesmo padrão de recombinação ao longo de todo o genoma e estão presentes em mais de três indivíduos sem relação epidemiológica evidente. Estas CRFs são designadas por números, que identificam a ordem de descoberta, e pelas letras correspondentes aos subtipos que as constituem. Se forem constituídas por mais de dois subtipos, são considerados CRFs complexas e designadas de CRFcpx (ROBERTSON et al., 2000).

A maioria das CRFs descritas está presente apenas em epidemias locais, como por exemplo, as CRF03_AB, CRF04_cpx, CRF05_DF, CRF07_BC, CRF08_BC e CRF10_CD (LAL; CHAKRABARTI; YANG, 2005). Entretanto, algumas são responsáveis pela maioria das novas infecções em certas regiões, tais como a CRF01_AE no sudeste da Ásia (CARR et al., 1996; GAO et al., 1996) e a CRF02_AG na África Ocidental e Central (CARR et al., 1998). Na Argentina, onde inicialmente a maioria dos isolados era do subtipo B (GOMEZ CARRILLO; PICCARDO; LIBONATTI, 1992), atualmente cerca de $80 \%$ dos isolados são recombinantes BF (AULICINO et al., 2007). Dentre as CRFs descritas, onze são recombinantes entre os subtipos B e F e metade delas foram descritas no Brasil (CRF28_BF, CRF29_BF, CRF39_BF, CRF40_BF, CRF46_BF) (DE SA FILHO et al., 2006; GUIMARAES et al., 2008; SANABANI et al., 2010). 


\subsubsection{Métodos de detecção de recombinação}

Além da sua importância na evolução do HIV, a recombinação tem um papel fundamental na evolução de muitos outros organismos (POSADA; CRANDALL; HOLMES, 2002; AWADALLA, 2003). Consequentemente, diferentes métodos foram e continuam sendo desenvolvidos para a análise de recombinação em alinhamentos de nucleotídeos (uma lista completa dos programas disponíveis pode ser encontrada em: http://www.bioinf.manchester.ac.uk/recombination/programs.shtml). Cada um destes algoritmos foi desenvolvido para avaliar diferentes aspectos da recombinação, como por exemplo, detectar evidência de recombinação, identificar potenciais recombinantes, determinar pontos de recombinação e determinar taxas de recombinação (LEMEY e POSADA, 2009). Estes algoritmos podem ser agrupados de acordo com a abordagem metodológica utilizada em:

(i) Métodos baseados em distância, que buscam por alterações nos padrões de distância genética entre sequências. Geralmente estes métodos utilizam algum tipo de medida de distância genética (por exemplo, similaridade ou dissimilaridade) entre os diferentes pares de sequência presentes no alinhamento. Estas medidas são calculadas em segmentos adjacentes do alinhamento movendo-se por exemplo, em segmentos de $200 \mathrm{nt}$ a cada $10 \mathrm{nt}$ (sliding window) (Figura 8). Os resultados são organizados em um gráfico com as medidas de distância representadas na ordenada e a posição no alinhamento na abscissa, e os eventos de recombinação são identificados por inversões no padrão de distância. Estes métodos foram implementados em programas como o SimPlot (LOLE et al., 1999), Recscan (MARTIN et al., 2005), RAT (ETHERINGTON; DICKS; ROBERTS, 2005) e RIP (SIEPEL et al., 1995).

(ii) Metódos baseados na distribuição de substituições, os quais comparam as sequências e avaliam se as substituições são uniformemente distribuídas. A nãouniformidade na distribuição das substituições é assumida como evidência de recombinação. Estes métodos foram implementados em programas como: GENECONV (SAWYER, 1989), MaxChi (MAYNARD SMITH, 1992), Phylpro (WEILLER et al., 1998), SiScan (GIBBS; ARMSTRONG; GIBBS, 2000), Chimaera (POSADA e CRANDALL, 2001), 3SEQ (BONI; POSADA; FELDMAN, 2007) e RDP3 (MARTIN et al., 2010). 


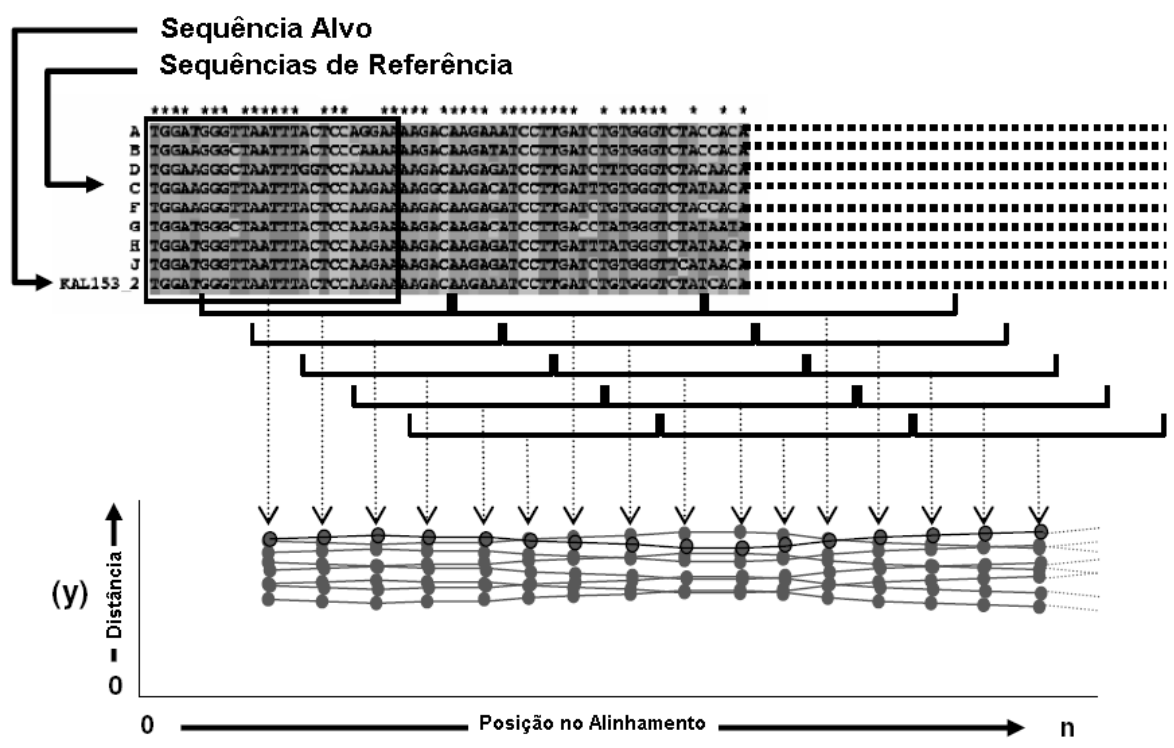

$(\mathrm{x})$

Figura 8- Esquema do procedimento de "janelas deslizantes" (sliding window) para avaliação de distâncias entre as sequências num alinhamento.

FONTE: Adaptado de Lemey e Posada (2009), com permissão.

(iii) Métodos baseados em inferência filogenética, os quais empregam reconstrução filogenética para avaliar a existência de incongruência entre topologias de árvores inferidas a partir de diferentes regiões do alinhamento de sequências. A existência de incongruência entre topologias é evidência de recombinação entre as sequências amostradas (Figura 9). Estes métodos foram implementados em programas como: Recpars (HEIN, 1993), PLATO (GRASSLY e HOLMES, 1997), TOPAL (MCGUIRE e WRIGHT, 2000), SimPlot (LOLE et al., 1999), BARCE (HUSMEIER e MCGUIRE, 2003), DualBrothers (SUCHARD et al., 2002; MININ et al., 2005), REGA (DE OLIVEIRA et al., 2005), GARD (POND et al., 2006), JAMBE (HUSMEIER; WRIGHT; MILNE, 2005) e RDP3 (MARTIN et al., 2010).

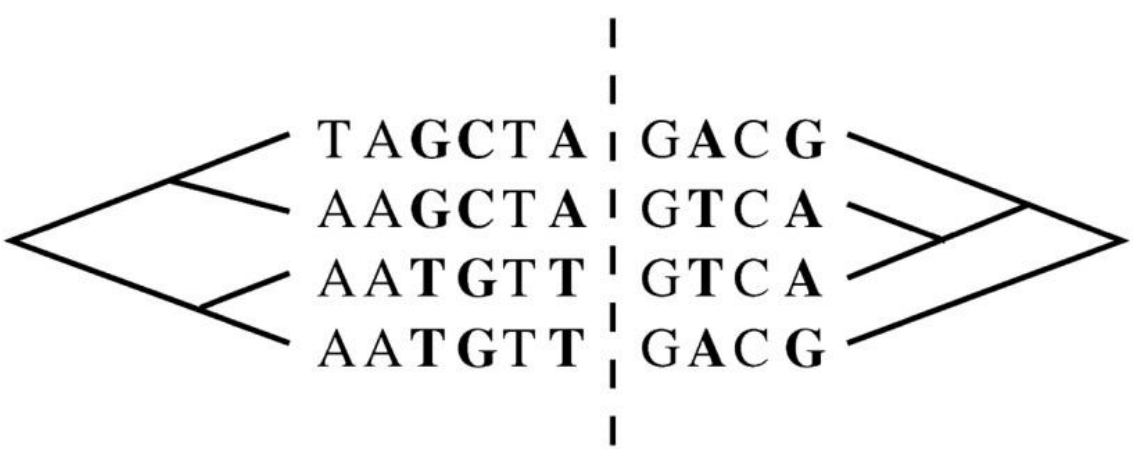

Figura 9- Reconstrução filogenética mostrando incongruência entre topologias inferidas a partir de diferentes regiões do alinhamento.

FONTE: Minin et al. (2007), com permissão. 
(iv) Métodos baseados em compatibilidade, os quais avaliam a incongruência filogenética usando uma análise sítio a sítio. Dois sítio são incompatíveis se não puderem ser incorporados numa árvore filogenética, sem assumir que um deles tenha sido alterado ao menos duas vezes (SNEATH; SACKIN; AMBLER, 1975; MAYNARD SMITH, 1999). Estes métodos não requerem conhecimento das relações filogenéticas entre as sequências amostradas. Estes métodos foram implementados em programas como: PARTIMATRIX (JAKOBSEN; WILSON; EASTEAL, 1997) e RETICULATE (JAKOBSEN e EASTEAL, 1996).

Dentre os métodos descritos acima, os embasados em distância (RIP e SimPlot) e inferência filogenética (SimPlot) são os mais utilizados para avaliação de recombinação em HIV-1 (SALMINEN e MARTIN, 2009). Os programas RIP e SimPlot calculam a similaridade dos segmentos adjacentes do alinhamento comparando a sequência alvo com um conjunto de sequências de referência, e alterações neste padrão de distância sugerem possíveis eventos de recombinação (Figura 10). Além do método de distância, o programa SimPlot também implementa o método de BOOTSCAN, que ao invés de estimar a similaridade entre as sequiências, usa um método de inferência filogenética. Ademais, os valores de suporte para cada agrupamento (bootstrap) são organizados em um gráfico semelhante ao apresentado na Figura 10 (SALMINEN et al., 1995). Este método também foi implementado nos programas REGA e RDP3. É importante destacar que o programa RDP3 é uma das melhores escolhas para análise de recombinação, uma vez que diferentes algoritmos foram implementados num único programa (Tabela 1), o que possibilita a avaliação independente e um sistema de "votação" por consenso metodológico (MARTIN et al., 2010).

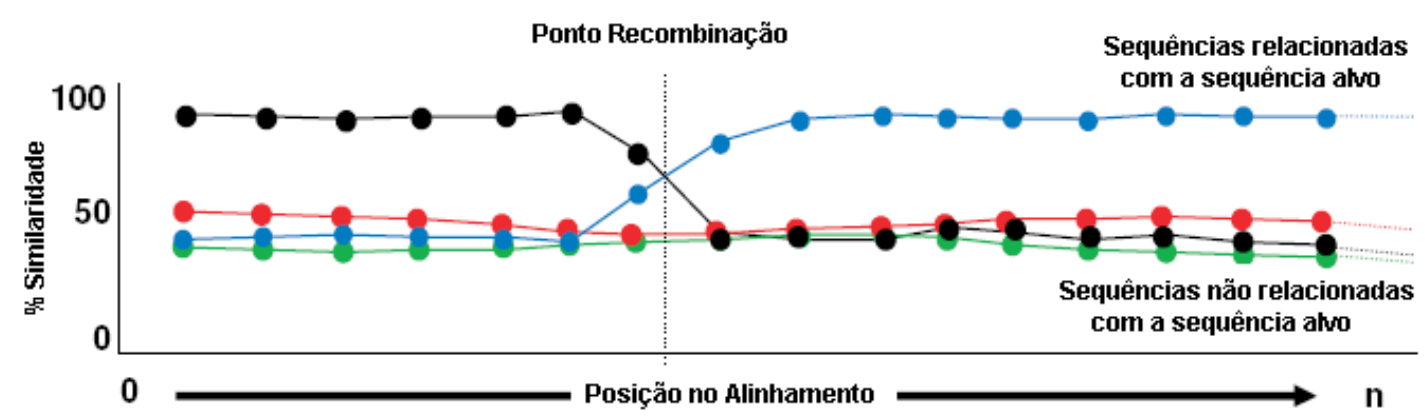

Figura 10- Esquema do perfil de uma sequência recombinante analisada por programas como o Simplot ou RIP. Como é possível observar nas primeiras posições do alinhamento a sequência alvo é mais similar à sequência de referência preta, e a partir da metade do alinhamento ela perde similaridade com esta sequência e torna-se mais similar à sequência de referência.

FONTE: Adaptado de Salminen e Martin (2009), com permissão. 
TABELA 1- Métodos de recombinação implementados no programa RDP3.

\begin{tabular}{cc}
\hline Métodos & Referências \\
\hline RDP & Martin e Rybicki (2000) \\
GENECONV & Padidam; Sawyer; Fauquet (1999) \\
BOOTSCAN & Salminen et al. (1995) \\
MaxChi & Maynard Smith (1992) \\
CHIMAERA & Posada e Crandall (2001) \\
Sister Scan & Gibbs; Armstrong; Gibbs (2000) \\
3SEQ & Boni; Posada; Feldman (2007) \\
LARD & Holmes; Worobey; Rambaut (1999) \\
Gráficos de distância & Martin et al. (2010) \\
PhylPro & Weiller et al. (1998) \\
DSS/TOPAL & Mcguire e Wright (2000) \\
VisRD & Lemey et al. (2009)
\end{tabular}

Recentemente um novo algoritmo para classificação e identificação de recombinantes em HIV-1 foi desenvolvido e implementado no programa jpHMM (jumping profile Hidden Markov Model, http://jphmm.gobics.de) (SCHULTZ et al., 2006; ZHANG et al., 2006). Este programa utiliza que utiliza uma abordagem probabilística para comparar uma sequência de nucleotídeos (S) a um alinhamento múltiplo (A), no qual cada sequência foi previamente classificada em famílias de sequência, no caso de HIV-1 em subtipos. Cada um destes grupos de sequência são então descritos como um modelo oculto de Markov, ou seja as sequências de um dado subtipo viral são utilizadas na construção de um modelo probabilístico que as represente (perfil-HMM) (Figura 11). A sequência $S$ é comparada aos perfis-HMM, entretanto é permitido que segmentos da sequência $S$ se alinhem localmente com perfis mais similares. Esta estratégia é particularmente útil para a identificação de sequências recombinantes, uma vez que estas são relacionadas a mais de um perfil-HMM. Crucialmente, esta abordagem probabilística empregada no programa jpHMM é bastante útil na classificação de sequências de HIV-1, pois considera a variação genética existente dentro de cada subtipo no alinhamento, e não depende da escolha de sequências parentais. 


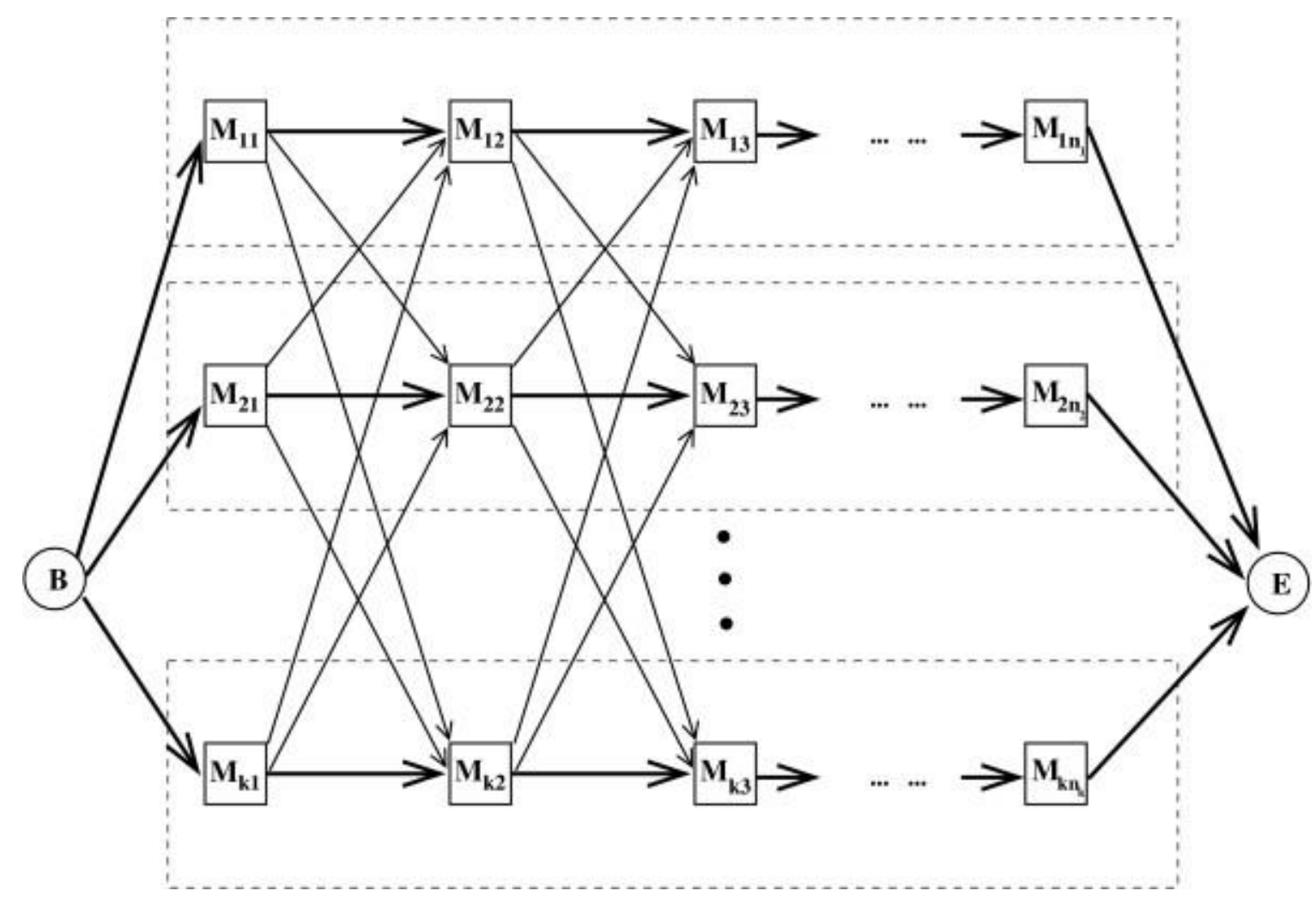

Figura 11- Esquema de funcionamento do programa jpHMM. Cada um dos retângulos pontilhados representa um grupo de sequências (subtipos). Para cada subtipo, modelos oculto de Markov são gerados, constituindo perfis HMM. As setas mais escuras indicam a probabilidade de transição entre sequências de um mesmo perfil e as setas finas representam a probabilidade de transição entre sequências de diferentes perfis. Dado um estado inicial $\mathrm{B}$, o programa calcula a probabilidade de que a sequência alvo pertença a aos perfis $\mathrm{M}_{1}, \mathrm{M}_{2}$ ou $\mathrm{M}_{\mathrm{k}}$. Na ausência de recombinação a sequência alvo é relacionada a apenas um destes perfis, ou seja não ocorre nenhum salto entre os diferentes perfis. $\mathrm{Na}$ presença de recombinação a sequência é relacionada a mais de um perfil, ou seja, a sequência alvo possui regiões relacionadas ao perfil $\mathrm{M}_{1}$ e regiões relacionadas ao perfil $\mathrm{M}_{\mathrm{k}}$.

FONTE: Schultz et al. (2006), com permissão.

\subsection{A EPIDEMIA BRASILEIRA E AS FORMAS RECOMBINANTES}

No Brasil 217 mil pessoas morreram em decorrência da AIDS até o final de 2009, e outras 630 mil podem estar infectadas por HIV. Somente no Estado de São Paulo, já ocorreram 94.343 óbitos por AIDS e pelo menos 72 mil pacientes estão sob tratamento antirretroviral. Entretanto, o número de indivíduos infectados no Estado é certamente maior, dado que nem todos os pacientes estão em tratamento ou conhecem seu status sorológico (DST/AIDS, SES-SP, 2010).

Embora o subtipo B seja mais frequente na maioria das regiões brasileiras, outros subtipos também são encontrados, como F, C, D e o A (MORGADO et al., 1998; BRINDEIRO et al., 1999; BONGERTZ et al., 2000; CARIDE, 2000; SOARES et al., 2003). 
$\mathrm{Na}$ região sul o subtipo $\mathrm{C}$ é a forma predominante, enquanto que em outras regiões está presente em menor frequência (BRINDEIRO et al., 2003; SOARES et al., 2005). O subtipo F por sua vez está presente em diversas regiões do Brasil (VICENTE et al., 2000; CABRAL et al., 2006; VERAS et al., 2007; RABONI et al., 2010). No entanto devido à alta frequência de recombinantes encontrados entre os subtipos B e F é difícil estimar com precisão a frequência do subtipo F "puro", sem o sequenciamento completo do genoma viral.

A descrição recente da CRF46_BF, ilustra muito bem esta questão. Curiosamente esta CRF possui o genoma quase inteiro do subtipo $\mathrm{F}$ e apenas uma pequena porção da LTR pertencente ao subtipo B (Figura 11), de modo que nenhuma das estratégias frequentemente utilizadas em estudos de epidemiologia molecular de HIV-1 seria capaz de reconhecê-la como uma forma recombinante (SANABANI et al., 2010).

A introdução de diferentes subtipos em uma única localidade e o crescimento da epidemia em muitas regiões do país, aliado ao aumento no número de estudos em epidemiologia molecular de HIV-1, tem gerado uma quantidade razoável de informação sobre a circulação e frequência de recombinantes em diversas regiões brasileiras, principalmente nos estados da Bahia, Rio Grande do Sul, Rio de Janeiro e São Paulo (SABINO et al., 1994; BRINDEIRO et al., 1999; TANURI et al., 1999; SA FILHO et al., 2005; CABRAL et al., 2006; BRENNAN et al., 2007; SA-FERREIRA et al., 2007; SUCUPIRA et al., 2007; VERAS et al., 2007; DE SOUZA et al., 2008; PASSAES et al., 2009b; TEIXEIRA et al., 2010). A maioria destes recombinantes descritos são URFs, entretanto alguns recombinantes foram capazes de se espalhar na epidemia e deram origem às diferentes CRFs descritas no Brasil (CRF31_BC e as diferentes CRFs_BF) (Figura 11) (VICENTE et al., 2000; DE SA FILHO et al., 2006; SANTOS et al., 2006; GUIMARAES et al., 2008; SANABANI et al., 2010). Apesar da importância destes recombinantes na epidemia brasileira, nenhum esforço foi realizado na obtenção e caracterização de isolados primários destas formas, e consequentemente nenhum estudo sobre características biológicas in vitro foi realizado.

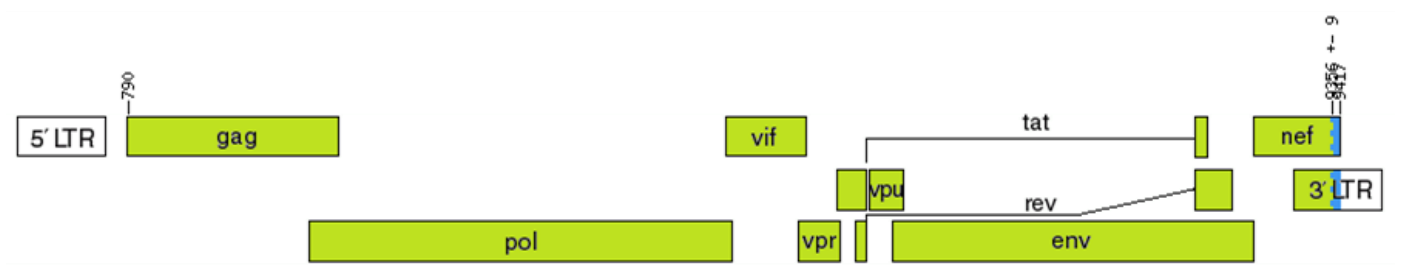

Figura 12- Perfil de recombinação da CRF46_BF descrita por Sanabani et al. (2010). O ponto de recombinação está situado no final da região codificadora do gene nef e se estende até o final da LTR. Perfil de recombinação gerado pelo programa jpHMM. As coordenadas são apresentadas em relação ao HXB2. 


\section{OBJETIVOS}

\subsection{OBJETIVO GERAL}

Identificar e caracterizar recombinantes de HIV-1 presentes na epidemia do Estado de São Paulo.

\subsection{OBJETIVOS ESPECÍFICOS}

- Identificar eventos de recombinação em sequências parciais dos genes gag, pol e env, geradas pelo projeto VGDN;

- Avaliar a frequência e distribuição de recombinantes nos municípios amostrados;

- Identificar possíveis recombinantes na região do gene da integrase e avaliar a ocorrência de polimorfismos de resistência aos inibidores de integrase, em uma parcela das amostras coletadas durante o VGDN;

- Isolar formas recombinantes entre os subtipos B e F, principalmente as CRF28_BF e CRF29_BF;

- Realizar o sequenciamento do genoma dos isolados primários e determinar o perfil de recombinação;

- Determinar o uso de coreceptores dos isolados primários. 


\section{MATERIAIS E MÉTODOS}

\subsection{CARACTERIZAÇÃO DAS SEQUÊNCIAS DE HIV-1 DO PROJETO VGDN}

Durante o projeto VGDN foram coletadas 1279 amostras de pacientes em diferentes regiões do Estado de São Paulo (PARDINI et al., 2008). Os centros de coleta foram os municípios de São Paulo (n=210), Ribeirão Preto (n=149), Araçatuba (n=150), São Vicente ( $n=150)$, Presidente Prudente $(n=151)$, Sorocaba $(n=154)$, São José do Rio Preto $(n=165)$ e Botucatu ( $\mathrm{n}=150)$. Entretanto, pacientes de muitos outros municípios do estado foram amostrados, uma vez que realizavam acompanhamento médico em um dos centros de coleta (Figura 13). A amplificação e sequenciamento foi realizada para os genes gag (p17), pol (pro-pol) e env ( gp120), em vários laboratórios (17) sob a concepção da Dra. Ester Sabino (IMT) e coordenação da Professora Dra Maria Inês Pardini (UNESP), da Dra. Leda Jamal (CRT/AIDS) e do Professor Dr. Paolo Marinho de Andrade Zanotto (USP).

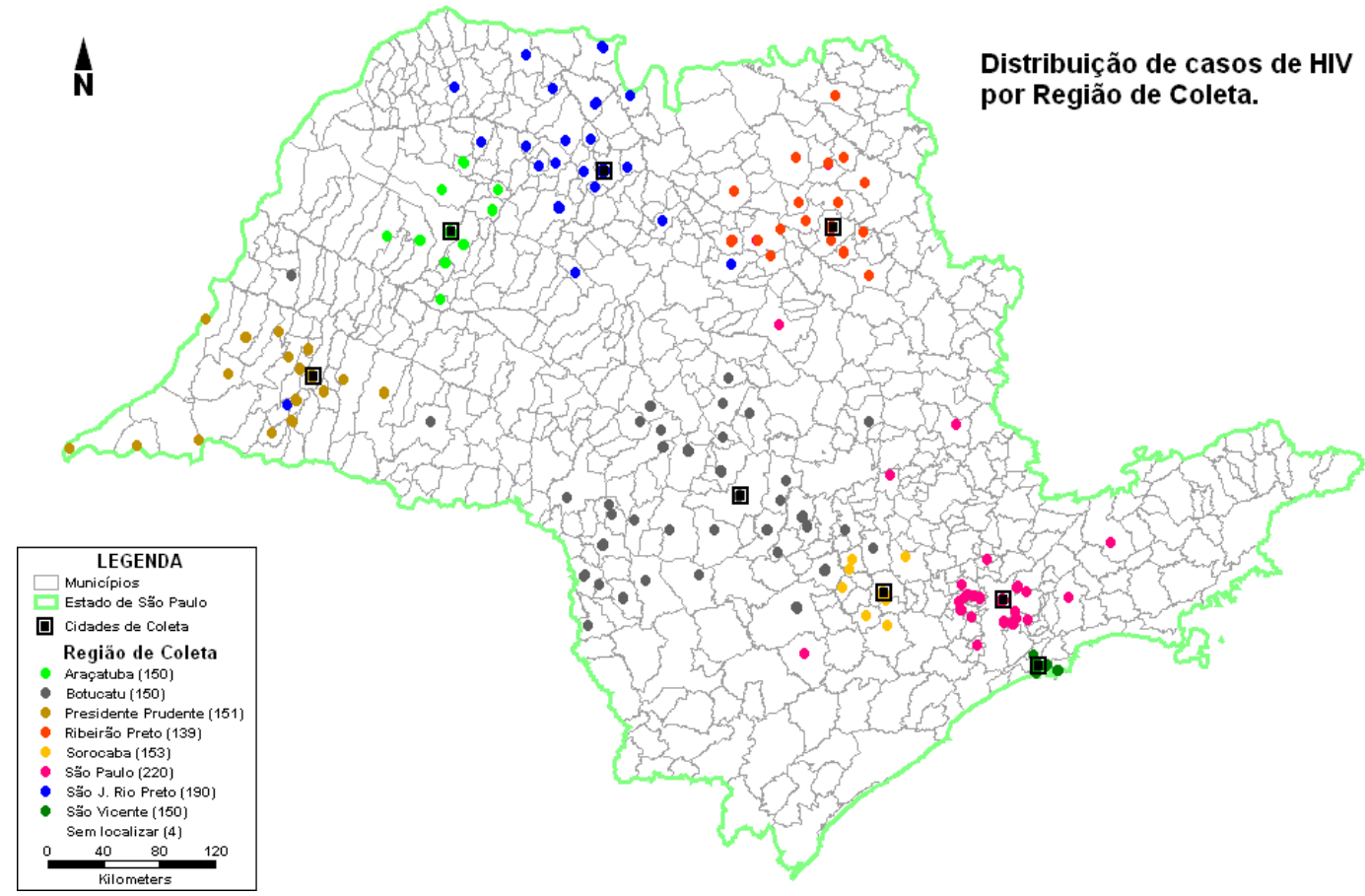

Figura 13- Distribuição espacial das amostras coletadas pelo projeto VGDN de acordo com o CEP da residência de cada um dos pacientes. Pontos de uma mesma cor foram coletados em um mesmo centros de coleta (quadrados pretos no mapa). Cada ponto pode representar mais de uma amostra. Mapa gerado pelo Dr. Reinaldo Paul Pérez Machado (Universidade de São Paulo, Faculdade de Filosofia Letras e Ciências Humanas, Departamento de Geografia). 


\subsubsection{Alinhamento, análise de recombinação e reconstrução filogenética}

Antes das análises de recombinação e reconstrução filogenética as sequências foram alinhadas com o programa MUSCLE (EDGAR, 2004), e as porções mais variáveis dos alinhamentos foram realinhadas com programa ClustalX (LARKIN et al., 2007). Posteriormente, estes alinhamentos foram manualmente inspecionados e editados com o auxílio do programa Se-A1 v2.0a.11 (RAMBAUT, 1996).

As análises de recombinação foram realizadas com os programas RDP3 (MARTIN; WILLIAMSON; POSADA, 2005; MARTIN et al., 2010) e jpHMM (SCHULTZ et al., 2006; ZHANG et al., 2006). Como descrito na seção 1.8.1, o programa jpHMM considera os polimorfismos existentes nos genomas sequenciados dos diferentes subtipos de HIV-1, por isso é menos sensível à escolha dos parentais, além disso determina os pontos de recombinação com incerteza associada, permitindo assim uma classificação mais acurada de grupos de recombinantes (SCHULTZ et al., 2009). Cada uma das sequências também foi avaliada pelo programa RDP, utilizando alguns dos algoritmos descritos na tabela 1 .

As reconstruções filogenéticas foram realizadas pelo método de máxima verossimilhança implementado no programa GARLI 0.951 (ZWICKL, 2006). Este programa utiliza um algoritmo genético estocástico que estima simultaneamente a topologia, comprimento de ramos e o modelo de substituição que maximizam o valor da verossimilhança, em sucessivas gerações. A cada nova geração a melhor solução é automaticamente escolhida e alterações nos valores dos diferentes parâmetros são executadas, visando um incremento continuo no valor da verossimilhança a cada nova reconstrução. $\mathrm{O}$ programa finaliza automaticamente após um número de gerações (especificado pelo usuário) sem incremento no valor da verossimilhança acima de um valor limite.

\subsubsection{Caracterização do gene da integrase}

Cento e cinquenta e nove amostras coletadas durante o projeto VGDN foram selecionadas para amplificação do gene da integrase, de acordo com o perfil de tratamento antirretroviral e da disponibilidade de DNA armazenado. A reação de amplificação foi realizada de acordo com o protocolo de nested-PCR descrito por Van Laethem et al. (2008). As concentrações dos reagentes e as sequências dos iniciadores utilizados nas reações de amplificação estão descritos nas tabelas 2 e 3, respectivamente. O protocolo de ciclagem da $1^{\text {a }}$ etapa foi o seguinte: $94{ }^{\circ} \mathrm{C}$ por $2 \mathrm{~min}, 35$ ciclos de $94{ }^{\circ} \mathrm{C}$ por $20 \mathrm{~s}, 53 \mathrm{C}{ }^{\circ} \mathrm{C}$ por $30 \mathrm{~s}$, e $72{ }^{\circ} \mathrm{C}$ 
por 2 min e uma extensão final de $10 \mathrm{~min}$ a $72{ }^{\circ} \mathrm{C}$. Ao final, $1 \mu \mathrm{l}$ desta reação foi transferido para uma nova etapa de amplificação com o segundo par de iniciadores (Tabela 3), com as mesmas condições de ciclagem. A amplificação dos fragmentos esperados foi confirmada por eletroforese em gel de agarose $0,8 \%$, corado com brometo de etídeo, e visualizado em sistema de transluminação com lâmpada UV. O sequenciamento foi realizado de acordo com o protocolo descrito na secção 3.3.3, utilizando os iniciadores descritos na Tabela 6 .

TABELA 2- Mistura de reação para amplificação do gene da integrase

\begin{tabular}{ccc}
\hline Componentes & Quantidade & [final] \\
\hline Tampão 10x & $5 \mu \mathrm{L}$ & $1 \mathrm{x}$ \\
dNTP Mix $[10 \mathrm{mM}]$ & $1 \mu \mathrm{L}$ & $200 \mu \mathrm{M}$ \\
$\operatorname{MgCl}_{2}[50 \mathrm{mM}]$ & $1,5 \mu \mathrm{L}$ & $1,5 \mathrm{mM}$ \\
Iniciador A (+) $[10 \mu \mathrm{M}]$ & $1 \mu \mathrm{L}$ & $500 \mathrm{nM}$ \\
Iniciador B (-) $[10 \mu \mathrm{M}]$ & $1 \mu \mathrm{L}$ & $500 \mathrm{nM}$ \\
DNA & $100-200 \mathrm{ng}$ & - \\
Platinum ${ }^{\circledR}$ Taq DNA Polimerase & $0,2 \mu \mathrm{L}$ & $1 \mathrm{U}$ \\
(Invitrogen) $[5 \mathrm{U} / \mu \mathrm{L}]$ & q.s.p. $50 \mu \mathrm{L}$ & - \\
$\mathrm{H}_{2} 0$ & &
\end{tabular}

Após o sequenciamento as amostras foram analisadas como descrito no item 3.1.1, para caracterização do subtipo e detecção de eventos de recombinação intragênica. Adicionalmente as amostras analisadas quanto ao perfil de resistência aos inibidores de integrase com auxilio do algoritmo de interpretação de resistência do HIV Drug Resistance Database (http://sierra2.stanford.edu/sierra/servlet/JSierra). 
TABELA 3- Iniciadores utilizados para amplificação e sequenciamento da integrase de HIV.

\begin{tabular}{|c|c|c|}
\hline ID & $\begin{array}{l}\text { Posição } \\
\text { (HXB2) }\end{array}$ & Sequência $\left(5^{\prime} \rightarrow 3^{\prime}\right)$ \\
\hline \multicolumn{3}{|l|}{$1^{a}$ etapa } \\
\hline KVL068 (+) ${ }^{1}$ & $3854-3880$ & AGGAGCAGAAACTTWCTATGTAGATGG \\
\hline KVL069 (-) ${ }^{1}$ & $5956-5982$ & TTCTTCCTGCCATAGGARATGCCTAAG \\
\hline \multicolumn{3}{|l|}{$\begin{array}{c}2^{\mathrm{a}} \text { etapa e } \\
\text { sequenciamento }\end{array}$} \\
\hline KVL070 $(+)^{1}$ & $4013-4041$ & TTCRGGATYAGAAGTAAAYATAGTAACAG \\
\hline KVL084 (-) $)^{1}$ & $5243-5265$ & TCCTGTATGCARACCCCAATATG \\
\hline \multicolumn{3}{|l|}{ Sequenciamento } \\
\hline HIV_4899_FW ${ }^{2}$ & $4899 \rightarrow 4920$ & CGGGTTTATTACAGGGACAGC \\
\hline HIV_4050_FW ${ }^{2}$ & $4050 \rightarrow 4070$ & TATGCATTAGGAATCATTCA \\
\hline
\end{tabular}

descritos por Van Laethem et al. (2008);

${ }^{2}$ desenhados para o sequenciamento do genoma.

\subsection{ISOLAMENTO VIRAL}

\subsubsection{Coleta e processamento das amostras}

Após análise das amostras do projeto VGDN, diferentes pacientes foram identificados como portadores de formas recombinantes de HIV-1. Para maximizar a probabilidade de isolamento viral cerca de 60 pacientes provenientes de diferentes cidades foram escolhidos. Todos os pacientes que concordaram em participar deste estudo assinaram um novo termo de consentimento livre e esclarecido (TCLE). Devido às limitações impostas pela quantidade de células mononucleares do sistema periférico sanguíneo (PBMC) saudáveis disponível para o isolamento por co-cultivo e também para facilitar a manipulação das amostras no laboratório, apenas 10 pacientes eram agendados por dia de coleta. Foram coletados dois tubos de $4 \mathrm{ml} \mathrm{de}$ sangue (Vacutainer/EDTA) de cada paciente. As coletas foram realizadas por pessoal qualificado nas unidades regionais do CRT/AIDS. As amostras provenientes da cidade de São Paulo e de São Vicente as amostras foram enviadas ao nosso laboratório cerca de 4h após a coleta. As amostras de Ribeirão Preto e Araçatuba foram processadas em nosso laboratório 24 e 36h após a coleta, respectivamente. Todas as amostras foram mantidas em temperatura ambiente até o momento do processamento.

As amostras foram centrifugadas a $1200 \mathrm{x}$ g por $10 \mathrm{~min}$ para separação do plasma, o qual foi aliquotado e armazenado a $-80^{\circ} \mathrm{C}$. O volume de plasma retirado foi substituído por 
PBS (pH 7.5, sem $\mathrm{Ca}^{++} / \mathrm{Mg}^{++}$) e as amostras processadas para a separação dos PBMCs em gradiente de densidade com Ficoll-Hypaque. Dois dias antes da coleta, PBMCs de doadores saudáveis foram descongelados e cultivados na presença de fitohemaglutinina (PHA).

\subsubsection{Isolamento por co-cultivo}

O isolamento viral foi realizado através do método de co-cultivo de PBMCs como descrito pelo DAIDS Virology Manual for HIV Laboratories (HOLLINGER et al., 1992). Cerca de $10^{7}$ PBMCs dos pacientes infectados foram co-cultivados com $10^{7}$ PBMC-PHA de doadores saudáveis gentilmente doados pelo Setor de Hemoterapia do Hospital Nove de Julho. A cada três dias, metade do meio era substituído e a cada sete dias eram adicionados mais $10^{7}$ PBMC-PHA. O sobrenadante de cultura retirado foi aliquotado e armazenado a -80 ${ }^{\circ} \mathrm{C}$ para posterior quantificação da proteína p24, indicativa de replicação viral. Ao final de quatro semanas os PBMCs foram coletados e crio-preservados em meio RPMI contendo $20 \%$ SFB e $10 \%$ de DMSO. O isolamento viral foi confirmado pela avaliação da proteína p24 utilizando o Kit Vironostika ${ }^{\circledR}$ HIV-1 Antigen (BioMérieux), segundo recomendações do fabricante. Foram analisados os sobrenadantes do último dia de cultivo sem diluição e a leitura foi realizada em leitor de microplacas a $450 \mathrm{~nm}$.

\subsubsection{Produção dos estoques virais}

A produção do estoque para os diferentes isolados foi realizada inoculando-se o sobrenadante viral em $4 \times 10^{7}$ PBMC-PHA utilizando dois ciclos de infecção, como descrito pelo DAIDS Virology Manual for HIV Laboratories (HOLLINGER et al., 1992). Inicialmente $4 \times 10^{7}$ PBMC-PHA foram preparados 2-3 dias antes do início da inoculação. No dia da inoculação os PBMC-PHA foram centrifugados a $400 \mathrm{x}$ g por $10 \mathrm{~min}$. O pellet celular foi ressuspendido em $1 \mathrm{ml}$ do sobrenadante viral, descongelado rapidamente em banho Maria a $37{ }^{\circ} \mathrm{C}$. Posteriormente, as células foram incubadas a $37{ }^{\circ} \mathrm{C}$ e $5 \% \mathrm{CO}_{2}$, por $2 \mathrm{~h}$ e agitadas suavemente a cada 20min. Após este período de incubação foram adicionados $20 \mathrm{ml}$ de meio RPMI e as células novamente centrifugadas a $400 \mathrm{x}$ g por $10 \mathrm{~min}$. O pellet celular foi ressuspendido em $1 \mathrm{ml}$ de sobrenadante de cultivo, incubado e lavado como descrito anteriormente. Finalmente as células foram ressuspendidas em meio de cultivo RPMI (15\% SFB, IL-2 [20 U/ml], Polibrene [2ug/ml] e Antibióticos) e incubadas $37{ }^{\circ} \mathrm{C}$ e $5 \% \mathrm{CO}_{2}$. No terceiro ou quarto dia, $20 \mathrm{ml}$ de sobrenadante de cada um dos frascos $\mathrm{T} 75$ foram retirados e 
congelados a $-80{ }^{\circ} \mathrm{C}$. As células foram então ressuspendidas no restante do sobrenadante, complementadas com meio de cultivo e divididas em dois frascos T75. No sétimo dia o mesmo procedimento foi adotado, entretanto mais $4 \times 10^{6}$ PBMC-PHA foram adicionados. No décimo dia de cultivo, todo o sobrenadante foi retirado e centrifugado a $400 \mathrm{x}$ g por $10 \mathrm{~min}$ a 4 ${ }^{\circ} \mathrm{C}$, o sobrenadante foi então aliquotado ( $1 \mathrm{ml} /$ tubo) e armazenado em nitrogênio. As células foram coletadas e crio-preservadas em meio RPMI contendo $20 \%$ SFB e $10 \%$ de DMSO, para posterior reamplificação ou extração de DNA.

\subsection{CARACTERIZAÇÃO GENÔMICA DOS RECOMBINANTES}

Para a determinação inequívoca do perfil de recombinação de uma amostra de HIV-1 é necessário o sequenciamento do genoma viral. Este procedimento foi realizado para todos os vírus isolados por co-cultivo.

\subsubsection{Extração de DNA}

A extração do DNA para amplificação do genoma do HIV-1 foi realizada utilizando-se o Kit QIAamp DNA Blood Blood (QIAgen), segundo as recomendações do fabricante. Inicialmente, $200 \mu \mathrm{L}$ de sangue total ou PBMCs foram adicionados em $200 \mu \mathrm{L}$ do tampão de lise $\mathrm{AL}$, homogeneizado por inversão e incubado a $56^{\circ} \mathrm{C}$ por $10 \mathrm{~min}$ com $20 \mu \mathrm{L}$ de proteinase K. Após incubação foram adicionados $200 \mu \mathrm{L}$ de etanol $100 \%$ seguido de homogeneização por inversão. A amostra foi aplicada em coluna de sílica e centrifugada a 6.000 x g por $1 \mathrm{~min}$. A coluna foi lavada com $500 \mu \mathrm{L}$ do tampão AW1, seguida de nova centrifugação a 6000 x g por 1min. Uma nova lavagem foi feita com $500 \mu \mathrm{L}$ do tampão AW2, seguido de centrifugação a 20000 x g por $3 \mathrm{~min}$. O sobrenadante foi retirado e a coluna novamente centrifugada para remoção do etanol residual. A coluna foi então transferida para um novo tubo e o DNA eluído em 100-200 $\mu$ L de água Milli-Q.

\subsection{2 nested-PCR para amplificação do genoma de HIV-1}

Duas estratégias foram utilizadas para a amplificação do provírus de HIV-1. A primeira amplifica um único fragmento de aproximadamente $9 \mathrm{~kb}$ utilizando o Kit Expand Long Template PCR System (Roche Applied Science), segundo o protocolo descrito por Carr et al. (1999), com modificações. Na primeira etapa foram utilizados os iniciadores MSF12b e 
OFMR1 e na segunda etapa os iniciadores F2nst e ofm19 (sequências descritas na Tabela 4). As concentrações dos reagentes na reação estão descrita na Tabela 5 A ciclagem foi realizada seguindo um protocolo de touchdown, com um ciclo inicial de $94{ }^{\circ} \mathrm{C}$ por $2 \mathrm{~min}, 15$ ciclos de: $94{ }^{\circ} \mathrm{C}$ por $20 \mathrm{~s}, 60{ }^{\circ} \mathrm{C}$ por 30 s (baixando $1{ }^{\circ} \mathrm{C}$ a cada 3 ciclos) e $68{ }^{\circ} \mathrm{C}$ por $1 \mathrm{~min} / \mathrm{kb}$. Em seguida, outros 20 ciclos de $94{ }^{\circ} \mathrm{C}$ por $20 \mathrm{~s}, 55{ }^{\circ} \mathrm{C}$ por 30 s e $68{ }^{\circ} \mathrm{C}$ por $1 \mathrm{~min} / \mathrm{kb}$ com uma extensão final por 10min. A ciclagem em touchdown foi escolhida porque diminui a formação de produtos inespecíficos, uma vez que os primeiros ciclos de amplificação são realizados em uma temperatura de hibridização maximamente estringente $\left(60-55^{\circ} \mathrm{C}\right)$. A amplificação dos fragmentos esperados foi confirmada por eletroforese em gel de agarose $0,8 \%$, corado com brometo de etídeo, e visualizado em sistema de transluminação com lâmpada UV.

A segunda estratégia amplifica o genoma de HIV-1 em três fragmentos, com sobreposição de cerca de 400 nucleotídeos para evitar a formação de recombinantes artificiais durante a montagem dos contigs (Figura 14). Os iniciadores utilizados para cada reação estão descritos na Tabela 4. Foram utilizadas as mesmas concentrações de reagentes e condições de ciclagem da estratégia anterior, apenas o tempo de extensão foi ajustado de acordo com o tamanho do fragmento.

TABELA 4- Descrição dos iniciadores utilizados para amplificação do genoma de HIV-1.

\begin{tabular}{cccc}
\hline ID & Etapa & $\begin{array}{c}\text { Posição } \\
(\mathbf{H X B} 2)\end{array}$ & Sequência $\left(\mathbf{5}^{\prime} \rightarrow \mathbf{3}^{\prime}\right)$ \\
\hline $\mathbf{1}^{\mathbf{0}}$ fragmento & & & \\
MSF12b $(+)^{1}$ & $1^{\text {a }}$ & $623 \rightarrow 649$ & AAATCTCTAGCAGTGGCGCCCGAACAG \\
F2nst $(+)^{1}$ & $2^{\text {a }}$ & $769 \rightarrow 793$ & GCGGAGGCTAGAAGGAGAGAGATGG \\
k2 $(-)^{2}$ & $1^{\text {a }}$ & $3309 \rightarrow 3335$ & TTTCCCCACTAACTTCTGTATGTCATTGACA \\
f2 $(-)^{3}$ & $2^{\text {a }}$ & $3301 \rightarrow 3321$ & GTATGTCATTGACAGTCCAGC \\
$\mathbf{2}^{\mathbf{o}}$ fragmento & & & \\
k1 $(+)^{2}$ & $1^{\text {a }}$ & $2147 \rightarrow 2166$ & CAGAGCCAACAGCCCCACCA \\
f1 $(+)^{3}$ & $2^{\text {a }}$ & $2519 \rightarrow 2539$ & GTTGACTCAGATTGGTTGCAC \\
VIFVPUout $(-)^{4}$ & $1^{\text {a }}$ & $6352 \rightarrow 6322$ & GGTACCCCATAATAATAGACTGTRACCCACAA \\
VIFVPUint $(-)^{4}$ & $2^{\text {a }}$ & $6231 \rightarrow 6256$ & CTCTCATTGCCACTGTCTTCTGCTC \\
$\mathbf{3}^{\mathbf{o}}$ fragmento & & & \\
ENVoutF1 $(+)^{4}$ & $1^{\text {a }}$ & $5500 \rightarrow 5575$ & AGARGAYAGATGGAACAAGCCCCAG \\
ENVintF1 $(+)^{4}$ & $2^{\text {a }}$ & $5861 \rightarrow 5885$ & TGGAAGCATCCRGGAAGTCAGCCT \\
ofm19 $(-)^{1}$ & $1^{\text {a }}$ & $9632 \rightarrow 9604$ & GCACTCAAGGCAAGCTTTATTGAGGCTTA \\
OFMR1 $(-)^{1}$ & $2^{\text {a }}$ & $9686 \rightarrow 9662$ & TGAGGGATCTCTAGTTACCAGAGTC \\
\hline
\end{tabular}

Tescritos por Carr et al. (1999); ${ }^{2}$ descritos por Kozal et al. (1996); ${ }^{3}$ descritos por Frenkel et al. (1995); ${ }^{4}$ descritos por Nadai et al. (2008) 
TABELA 5- Mistura de reação para amplificação do genoma de HIV.

\begin{tabular}{ccc}
\hline Componentes & Quantidade & [final] \\
\hline Tampão 1 [10x] & $5 \mu \mathrm{L}$ & $1 \mathrm{x}$ \\
dNTP Mix $[10 \mathrm{mM}]$ & $1,7 \mu \mathrm{L}$ & $350 \mu \mathrm{M}$ \\
Iniciador A (+) $[10 \mu \mathrm{M}]$ & $1 \mu \mathrm{L}$ & $500 \mathrm{nM}$ \\
Iniciador B (-) $[10 \mu \mathrm{M}]$ & $1 \mu \mathrm{L}$ & $500 \mathrm{nM}$ \\
DNA & $10-200 \mathrm{ng}^{1}$ & - \\
Expand Enzime Mix $[5 \mathrm{U} / \mu \mathrm{L}]$ & $0,75 \mu \mathrm{L}$ & $3,75 \mathrm{U}$ \\
$\mathrm{H}_{2} 0$ & q.s.p. $50 \mu \mathrm{L}$ & - \\
\hline
\end{tabular}

diferentes diluições do DNA foram utilizadas
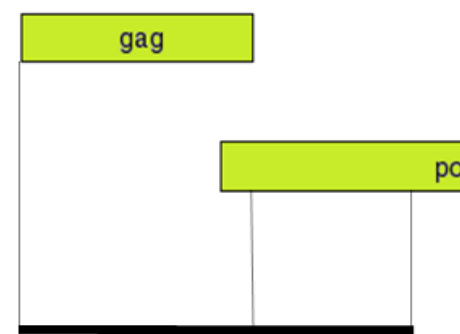

pol

$1^{\circ}$ Fragmento $(2.5 \mathrm{~kb})$

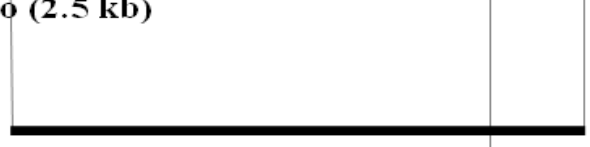

$2^{\circ}$ Fragmento $(3.7 \mathrm{~kb})$

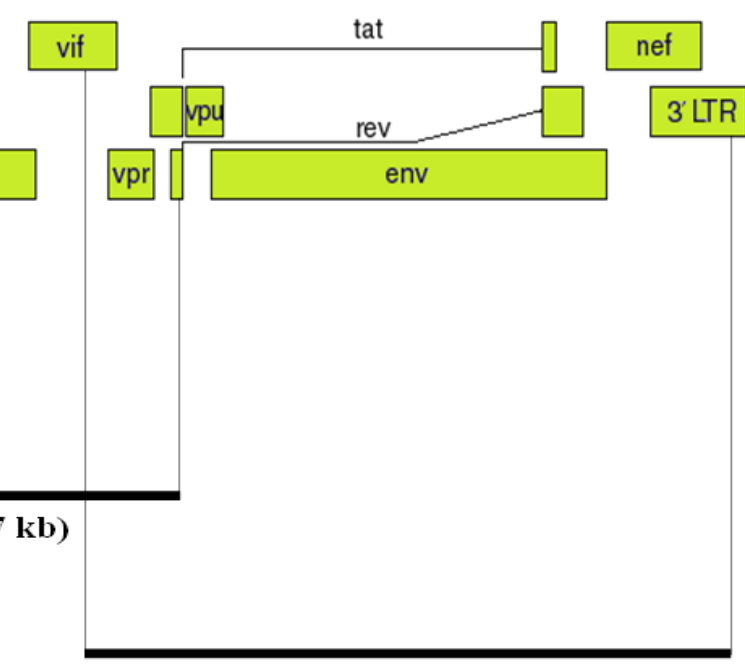

$3^{\circ}$ Fragmento $(3.8 \mathrm{~kb})$

Figura 14- Desenho esquemático do genoma de HIV-1 com o a localização e tamanho dos três fragmentos amplificados para o sequenciamento do genoma das formas recombinantes. 


\subsubsection{Reação de sequenciamento}

As reações de sequenciamento foram realizadas pelo método de terminação de cadeia (método de Sanger), utilizando o Kit BigDye Terminator v.3.0 (Applied Biosystem) e os iniciadores descritos na tabela 6. Para a reação de sequenciamento foram utilizados 50-150 ng do produto de PCR, $1 \mu \mathrm{L}$ de BDT, $3 \mu \mathrm{L}$ de tampão de sequenciamento, 3.2 pmol do primer e $\mathrm{H}_{2} 0$ para $10 \mu \mathrm{L}$. O protocolo de ciclagem foi o seguinte: $96^{\circ} \mathrm{C}$ por $2 \mathrm{~min}$, seguido de 35 ciclos de $96{ }^{\circ} \mathrm{C}$ por 30 s, $52{ }^{\circ} \mathrm{C}$ por 30 s e $60{ }^{\circ} \mathrm{C}$ por $4 \mathrm{~min}$. Os produtos obtidos na reação de sequenciamento foram precipitados em isopropanol e etanol para a remoção dideoxinucleotideos não incorporados. Seguindo as recomendações do fabricante, foram adicionados $40 \mu \mathrm{L}$ de isopropanol $65 \%$ aos $10 \mu \mathrm{L}$ da reação de sequenciamento, a reação foi então incubada por $15 \mathrm{~min}$ em temperatura ambiente. Após este período a amostra foi centrifugada por $30 \mathrm{~min}$ a $3.000 \mathrm{x}$ g. O sobrenadante foi retirado por inversão, posteriormente foram adicionadas $150 \mu \mathrm{L}$ de etanol $60 \%$ e a amostra centrifugada por $10 \mathrm{~min}$ a $3.800 \mathrm{x}$ g. O sobrenadante foi então retirado por inversão e o pellet foi mantido a $96{ }^{\circ} \mathrm{C}$ por $2 \mathrm{~min}$, para eliminação do etanol residual. O DNA precipitado foi ressuspendido em $10 \mu \mathrm{L}$ de $\mathrm{Hi}$-Di Formamida (Applied Biosystems), desnaturado a $96{ }^{\circ} \mathrm{C}$ por $3 \mathrm{~min}$ e mantido em gelo por $5 \mathrm{~min}$. Posteriormente as amostras foram analisadas no sequenciador automático ABI-PRISM 3100 (Applied Biosystems). Após sequenciamento, os eletroferogramas foram avaliados e os contigs montados com o programa CodonCode Alignner V 3.0.2. 
TABELA 6- Iniciadores utilizados para o sequenciamento de HIV.

(continua)

\begin{tabular}{|c|c|c|}
\hline ID & Posição (HXB2) & Sequência $\left(5^{\prime} \rightarrow 3^{\prime}\right)$ \\
\hline F2nst & $769 \rightarrow 793$ & GCGGAGGCTAGAAGGAGAGAGATGG \\
\hline HU1 & $796 \rightarrow 816$ & GCGAGAGCGTCAGTATTAAGC \\
\hline K1 & $2147 \rightarrow 2166$ & CAGAGCCAACAGCCCCACCA \\
\hline HL1 & $2149 \rightarrow 2129$ & GGGGTCTGCTCTGAAGAAAAT \\
\hline HU2 & $1763 \rightarrow 1783$ & ATGCGAACCCAGATTGTAAGA \\
\hline HL2 & $3337 \rightarrow 3318$ & TTTCCCACTAACTTCTGTGAT \\
\hline HU3 & $2838 \rightarrow 2858$ & CCAGCAGGGTTAAAAAAGAAA \\
\hline HL3 & $4081 \rightarrow 4061$ & TCTGGTTGTGCTTGAATGATT \\
\hline HU4 & $3625 \rightarrow 3645$ & CTGCCCACACTAATGATGTAA \\
\hline HL4 & $5077 \rightarrow 5057$ & CCTGCCACACAATCATCACCT \\
\hline HU5 & $4494 \rightarrow 4514$ & ATCCCAGCAGAAACAGGACAG \\
\hline HL5 & $5808 \rightarrow 5788$ & AATGCCTATTCTGCTATGTTG \\
\hline HU6 & $5180 \rightarrow 5200$ & GGCATCCAAAAGTAAGTTCAG \\
\hline HL6 & $6984 \rightarrow 6964$ & CTGGCTTAATTCCATGTGTAC \\
\hline HU7 & $6457 \rightarrow 6477$ & ACCCCAACCCACAAGAAATAG \\
\hline HL7 & $8212 \rightarrow 8192$ & AATGCCAATAAGTCTTGTTCA \\
\hline HU8 & $7631 \rightarrow 7651$ & ACCTGGAGGAGGAGATATGAG \\
\hline HL8 & $9223 \rightarrow 9202$ & AGCACCATCCAAAGGTCAGTG \\
\hline $\mathrm{F} 1$ & $2519 \rightarrow 2539$ & GTTGACTCAGATTGGTTGCAC \\
\hline G1 & $2800 \rightarrow 2820$ & CTCARGACTTYTGGGAAGTTC \\
\hline $\mathrm{F} 2$ & $3321 \rightarrow 3301$ & GTATGTCATTGACAGTCCAGC \\
\hline DP10 & $2198 \rightarrow 2223$ & TAACTСССТСТCAGAAGCAGGAGCCG \\
\hline DP11 & $2572 \rightarrow 2598$ & TACCAGTAAAATTAAAGCCAGGAATGG \\
\hline $\mathrm{G} 2$ & $2890 \rightarrow 2869$ & GCATCHCCCACATCYAGTACTG \\
\hline
\end{tabular}


TABELA 6- Iniciadores utilizados para o sequenciamento de HIV. (conclusão)

\begin{tabular}{|c|c|c|}
\hline ID & Posição (HXB2) & Sequência $\left(5^{\prime} \rightarrow 3^{\prime}\right)$ \\
\hline $333 \mathrm{~F}$ & $3081 \rightarrow 3102$ & ATARTTATCTATCAATACATGG \\
\hline $333 R$ & $3604 \rightarrow 3581$ & CCTGTTTTYAGATTTTTAAATGCG \\
\hline $\mathrm{K} 2$ & $3335 \rightarrow 3309$ & TTTCCCCACTAACTTCTGTATGTCATTGACA \\
\hline HIV_6206_FW & $6206 \rightarrow 6229$ & AGAGCAGAAGACAGTGGCAATGA \\
\hline ENV_OUTF1_FW & $5500 \rightarrow 5575$ & AGARGAYAGATGGAACAAGCCCCAG \\
\hline ENV_INTF1_FW & $5861 \rightarrow 5885$ & TGGAAGCATCCRGGAAGTCAGCCT \\
\hline VIFVPUOUT_RV & $6352 \rightarrow 6322$ & GGTACCCCATAATAATAGACTGTRACCCACAA \\
\hline VIFVPUINT_RV & $6231 \rightarrow 6256$ & CTCTCATTGCCACTGTCTTCTGCTC \\
\hline HIV_4899_FW & $4899 \rightarrow 4920$ & CGGGTTTATTACAGGGACAGC \\
\hline HIV_3235_FW & $3235 \rightarrow 3257$ & GGATGGGRTATGAACTCCATCC \\
\hline HIV_4050_FW & $4050 \rightarrow 4070$ & TATGCATTAGGAATCATTCA \\
\hline NHU5 & $4448 \rightarrow 4468$ & CCTGGTAGCAGTCCATGTAGC \\
\hline GCO & $1322 \rightarrow 1297$ & CCCATGTTTTCAGCATTATCAGAAGG \\
\hline ED5 & $6557 \rightarrow 6582$ & ATGGGATCAAAGCCTAAAGCCATGTG \\
\hline ED31 & $6817 \rightarrow 6845$ & CCTCAGCCATTACACAGGCCTG \\
\hline ES7 & $7002 \rightarrow 7021$ & CTGTTAAATGGCAGTCTAGC \\
\hline ED33 & $7381 \rightarrow 7360$ & TTACAGTAGAAAAATTCCCCTC \\
\hline ES8 & $7668 \rightarrow 7648$ & CACTTCTCCAATTGTCCCTCA \\
\hline ED12 & $7811 \rightarrow 7782$ & AGTGCTTCCTGCTGCTCCCAAGAACCCAAG \\
\hline NNI & $8788 \rightarrow 8810$ & TGCTATAAGATGGGTGGCAAGTG \\
\hline NNO & $8752 \rightarrow 8774$ & TACCTAGAAGAATAAGACAGGGC \\
\hline Ofm19 & $9632 \rightarrow 9604$ & GCACTCAAGGCAAGCTTTATTGAGGCTTA \\
\hline
\end{tabular}




\subsection{CARACTERIZAÇÃO DO USO DE CORRECEPTORES}

\subsubsection{Análise in vitro do uso de correceptores}

Para a caracterização do uso de correceptores foram utilizadas as células GHOST(3), que expressam CD4 e CCR5 ou CXCR4 e apresentam o gene gfp sob o controle da LTR de HIV-2 (MORNER et al., 1999). Este sistema apresenta uma maior facilidade de análise dos resultados, visto que as células infectadas podem ser visualizadas em microscópio de fluorescência dois dias após inoculação. Estas células foram gentilmente doadas pelo AIDS Research and Reference Reagent Program e foram mantidas em DMEM contendo 10\% SFB, Penicilina/Streptomicina, $100 \mu \mathrm{g} / \mathrm{ml}$ de Higromicina e $500 \mu \mathrm{g} / \mathrm{ml} \mathrm{G} 418$. Todas as linhagens foram mantidas a $37{ }^{\circ} \mathrm{C}$ e $5 \% \mathrm{CO}_{2}$. Para as células que expressam CCR5 ou CXCR4 foi adicionado ao meio de cultivo $1 \mu \mathrm{g} / \mathrm{ml}$ de puromicina.

No dia anterior a infecção, as células GHOST(3) Parental (CD4+), GHOST(3) CCR5 (CD4+ e CCR5+) e GHOST(3) CXCR4 (CD4+ e CXCR4+) foram crescidas em placas de 24 poços $\left(6 \times 10^{4}\right.$ células/poço) a $37^{\circ} \mathrm{C}$ e $5 \% \mathrm{CO}_{2}$. No dia seguinte, o meio foi retirado e as células lavadas com PBS ( $\mathrm{pH} 7.5$, sem $\mathrm{Ca}^{++} / \mathrm{Mg}^{++}$). Após a lavagem, foram adicionados $300 \mu \mathrm{L}$ do estoque viral em cada uma das linhagens. As células foram então incubadas a 37 ${ }^{\circ} \mathrm{C}, 5 \% \mathrm{CO}_{2}$ por $2 \mathrm{~h}$. Ao final desse período, mais $300 \mu \mathrm{L}$ de meio DMEM foram adicionados e as células foram incubadas por mais $18 \mathrm{~h}$. Após esse período, o meio contendo o inóculo viral foi retirado e a monocamada celular foi lavada com PBS. Para cada uma das linhagens foi realizado controle de células não infectadas. Após $48 \mathrm{~h}$, as células foram fixadas com paraformaldeido $4 \%$ por $1 \mathrm{~h}$, coradas com DAPI e observadas em microscópio de fluorescência invertido (Olympus, IX51). A replicação viral nas células GHOST(3) pode ser evidenciada pela presença de sincícios fluorescentes ou por células fluorescentes isoladas. Após verificação dos focos fluorescentes os vírus foram caracterizados de acordo com o receptor de quimiocina utilizado. Se os vírus inoculados fossem capazes de infectar somente células que expressam CCR5, eram denominados R5, se infectassem células que expressam CXCR4, eram classificados como X4, e se foram capazes de infectar ambas as linhagens eram classificados como R5/X4 ou duplo trópicos.

Como todas as linhagens GHOST(3) expressam CXCR4 endógeno em níveis basais, o uso do receptor CCR5 pelos diferentes isolados foi confirmado utilizando o inibidor de CXCR4 bicyclam AMD3100, uma vez que vírus que utilizam exclusivamente CXCR4 não capazes de infectar nenhuma das linhagens de células GHOST(3) na presença do inibidor. No 
dia anterior a infecção, as células GHOST(3) CCR5 e GHOST(3) CXCR4 foram crescidas em placas de 24 poços $\left(4-6 \times 10^{4}\right.$ células/poço) a $37^{\circ} \mathrm{C}$ e $5 \% \mathrm{CO}_{2}$. No dia seguinte, o meio foi retirado e as células lavadas com PBS. As células foram incubadas por $1 \mathrm{~h}$ a $37^{\circ} \mathrm{C}$ em $5 \%$ $\mathrm{CO}_{2}$ com DMEM contendo $1 \mu \mathrm{M}$ do inibidor AMD3100. Após este período, o meio foi retirado e $500 \mu \mathrm{l}$ do estoque viral contendo $1 \mu \mathrm{M}$ do inibidor foram adicionados. Após incubação por duas horas a $37^{\circ} \mathrm{C}$ e $5 \% \mathrm{CO}_{2}$, o inóculo viral foi retirado e a monocamada celular lavada com PBS. Após $48 \mathrm{~h}$, as células foram fixadas com paraformaldeido $4 \%$ por 1h, coradas com DAPI e observadas em microscópio de fluorescência invertido para confirmação da infecção viral. Vírus sensíveis ao inibidor não foram capazes de induzir fluorescência ou formar sincício.

\subsubsection{Análise in silico do uso de correceptores}

Paralelamente aos ensaios fenotípicos, as sequências de aminoácidos da alça V3 (35aa em média) de cada um dos isolados foram submetidas a dois algoritmos de predição de tropismo e/ou coreceptores. O primeiro algoritmo empregado foi o algoritmo PSSM (position-specific scoring matrices), que utiliza matrizes de pontuação específica para cada posição do alinhamento de sequências previamente fenotipadas, sendo que as colunas nesta matriz representam as posições de aminoácidos na alça e cujas linhas representam os possíveis resíduos. Para cada sequência é atribuída uma pontuação somando-se as células da matriz que correspondem aos aminoácidos em cada posição. Os vírus são classificados em R5 ou X4 de acordo com um limiar previamente estabelecido de -2,88 e -6,96, respectivamente. Portanto sequências com pontuações menores que $-6,96$, são classificadas como R5, e aquelas com pontuações maiores que -2,88 são classificadas como X4 (JENSEN et al., 2003). O segundo algoritmo foi o geno2pheno [co-receptor]. Este algoritmo emprega um método estatístico de aprendizado denominado máquinas de vetores suporte (SVMs, Support Vector Machines). Recentemente este algoritmo foi descrito como sendo o mais sensível na detecção de variantes capazes de utilizar CXCR4 (SANCHEZ et al., 2010). Para as análises foi utilizada uma taxa de falso-positivos de $20 \%$, uma vez que este valor minimiza a possibilidade de classificação errônea um isolado X4 como R5. 


\section{RESULTADOS E DISCUSSÃO}

\subsection{CARACTERIZAÇÃO DAS AMOSTRAS SEQUENCIADAS NO PROJETO VGDN}

\subsubsection{Frequência dos subtipos e distribuição espacial}

Como descrito na seção 3.1, durante a execução do projeto VGDN foram coletadas amostras em diferentes municípios do Estado de São Paulo (Figura 15-A e 15-B). A sobreposição do mapa de distribuição destas amostras com uma imagem por satélite das luzes noturnas do Estado de São Paulo (Figura 15-C) sugere que a maioria dos focos urbanos (áreas com maior intensidade luminosa) foi representada nesta amostragem, com exceção das regiões próximas aos municípios de Bauru, Campinas e São José dos Campos, onde não houve nenhum ponto de coleta. Esta ampla amostragem de municípios nunca havia sido realizada no Brasil e a maioria dos estudos em epidemiologia molecular de HIV-1 foi realizada nas capitais dos estados (TANURI et al., 1999; VICENTE et al., 2000; BRINDEIRO et al., 2003; CABRAL et al., 2006; BRENNAN et al., 2007; SA-FERREIRA et al., 2007; STEFANI et al., 2007; VERAS et al., 2007; DE SOUZA et al., 2008).

Dos 1279 pacientes amostrados pelo projeto VGDN, foram geradas sequências para 1083 pacientes. Infelizmente, não foi possível obter sequências de gag, pol (pro-pol) e env para todos os pacientes. Ao todo foram geradas 557, 753 e 761 sequências de $g a g$, pol e $e n v$, respectivamente (Figura 15-D). Cada uma destas sequências foi analisada para a determinação do subtipo viral e evidência de recombinação. Para facilitar as análises posteriores, cada paciente foi renomeado de acordo com o subtipo viral para cada dos genes disponíveis (por exemplo, $\mathrm{ID}_{\mathrm{VGDN} \_\mathrm{gBpBeB}}$ ), e foram classificados como portadores de formas recombinantes caso $(i)$ apresentassem evidência de recombinação intragênica, ou seja, com pontos de recombinação dentro do gene avaliado (por exemplo, IDVGDN_pBF), ou caso (ii) houvesse discordância de subtipos entre os genes disponíveis (por exemplo,

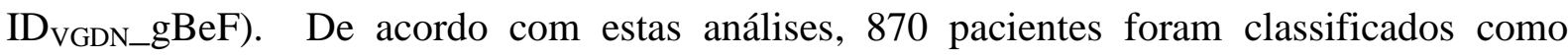
portadores de vírus do subtipo B, e 212 como portadores de outros subtipos. Dentre as amostras de subtipos não-B, 44 foram classificadas como F, sete como C, duas como D, 152 como recombinantes BF, três como CRF31_BC, dois como BD, um como BCF, e uma amostra, proveniente de um paciente chinês, foi classificada como CRF01_AE. 
A)

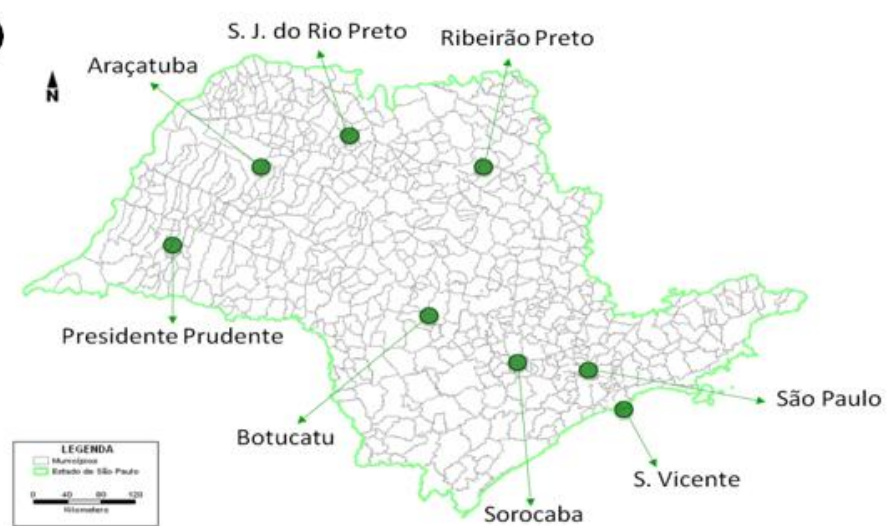

C)

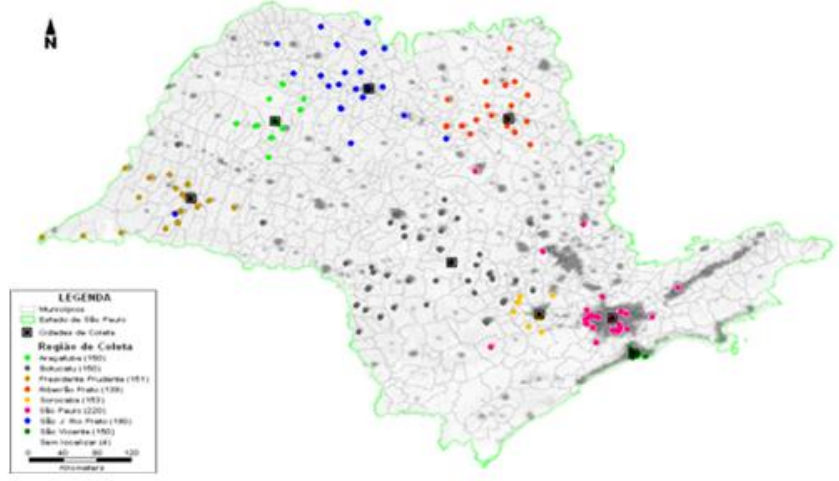

B)

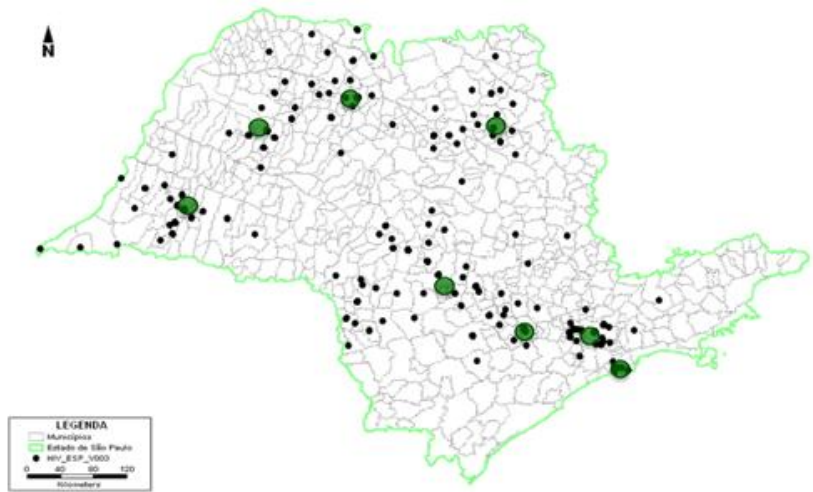

D)

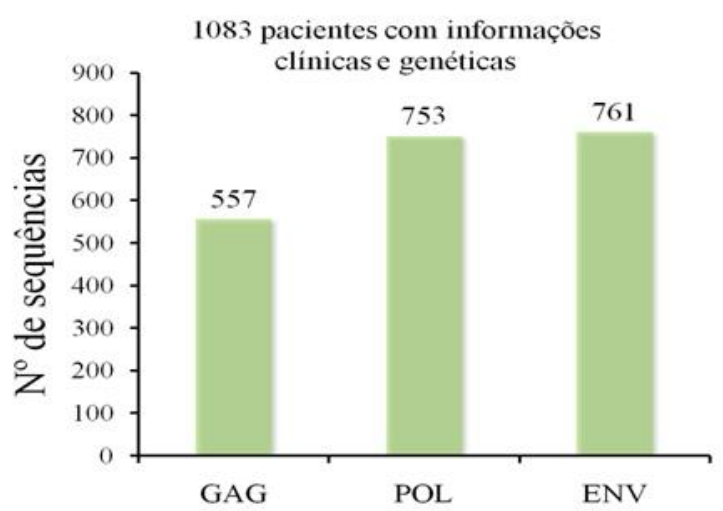

Figura 15- A) Pontos de coleta do projeto VGDN. B) Distribuição espacial dos pacientes coletados, segundo dados de domicílio. Cada ponto preto pode representar mais de um paciente. C) Sobreposição do mapa mostrado na Figura 12 com uma imagem de satélite das luzes noturnas do Estado de São Paulo; regiões mais escuras são as de maior intensidade luminosa e, consequentemente, maior densidade populacional. A sobreposição dessas áreas escuras com os dos pontos coloridos demonstra que a maioria das regiões densamente habitadas foi incluída na amostragem do projeto VGDN. D) Gráfico do número de sequências geradas pelo projeto VGDN de acordo com a região do genoma. É importante notar que a soma do número de sequências para cada gene não corresponde ao total de pacientes sequenciados, uma vez que os pacientes podem apresentam sequências para mais de uma região do genoma. Mapa gerado pelo Dr. Reinaldo Paul Pérez Machado (Universidade de São Paulo, Faculdade de Filosofia Letras e Ciências Humanas, Departamento de Geografia). 
É importante ressaltar que o número de recombinantes BF pode ser maior, uma vez que eventos de recombinação podem ter ocorrido em regiões do genoma não sequenciadas das amostras classificadas como subtipos B e F. Outro aspecto importante é a recombinação entre linhagens de um mesmo subtipo, que não será abordado neste trabalho devido às dificuldades técnicas inerentes à análise desse tipo de evento.

Como é possível observar na Figura 16, a frequência de recombinantes BF variou entre os diferentes pontos de coleta, atingindo 30 \% em São Vicente, 22,6 \% em Sorocaba, 14,5\% em Ribeirão Preto, Presidente Prudente, Botucatu, Araçatuba, São José do Rio Preto e São Paulo. Esta alta frequência de recombinantes na região de São Vicente é coerente com resultados de outros trabalhos realizados na região de Santos (SUCUPIRA et al., 2007) e com o próprio perfil da cidade, uma vez que esta é um grande centro urbano situado no litoral e próximo a uma região portuária. Entretanto, os altos níveis encontrados em cidades do interior como Sorocaba e Ribeirão Preto ainda não haviam sido descritos e confirmam a importância epidemiológica destes recombinantes no Estado de São Paulo. Além disso, a frequência de recombinantes BF em Sorocaba pode ser muito maior, visto que para muitas amostras classificadas como subtipo $\mathrm{F}$ apenas o gene env foi sequenciado.

Exceto pela cidade de São Paulo, aparentemente a diminuição na frequência de ocorrência dos recombinantes segue um gradiente do litoral em direção ao interior do estado, de maneira que as menores frequências encontradas estão nas cidades mais a oeste, como Araçatuba e São José do Rio Preto. Isto sugere que os vírus recombinantes apresentam um papel importante na colonização de epidemias recentes. Enquanto que em cidades como São Paulo e Rio de Janeiro, onde a presença do subtipo B é mais antiga, estes recombinantes não se espalharam tão eficientemente e estão presentes em baixas frequências $5-8 \%$ e $4 \%$, respectivamente (DE SOUZA et al., 2008; GUIMARÃES et al., 2010).

Portanto, para tentar compreender a distribuição espacial e avaliar a existência de agrupamentos regionais destas amostras, as relações filogenéticas entre estas sequências foram inferidas pelo método de máxima verossimilhança. Todas as sequências com evidência de recombinação intragênica foram retiradas antes das análises, uma vez que os eventos de recombinação mesclam em um único genoma diferentes histórias evolutivas, o que altera o resultado do processo de reconstrução filogenética.

Como é possível observar na figura 17, a genealogia do gene gag revelou que algumas amostras do subtipo B agruparam-se com amostras identificadas como recombinantes na região do gene $p o l$, provenientes da região de São Vicente e relacionadas às CRFs 28 e 29. Este perfil de agrupamento pode ser entendido de duas maneiras: $(i)$ o padrão indica que estas 
amostras são formas "puras" do subtipo B relacionadas à linhagem parental B que deu origem a estes recombinantes ou, (ii) indica que estas amostras são recombinantes não identificados, uma vez que em muitos destes casos não foi possível sequenciar o gene pol, o que permitiria identificá-las como pertencentes a alguns dos grupos de recombinantes pol BF. Apesar de a primeira alternativa ser plausível, a segunda é reforçada pelo fato de que a maioria destes pacientes reside na região de São Vicente, onde a frequência de recombinantes foi extremamente elevada (30 \%, Figura 16), corroborando o fato de que a proporção de recombinantes em uma epidemia é frequentemente subestimada.

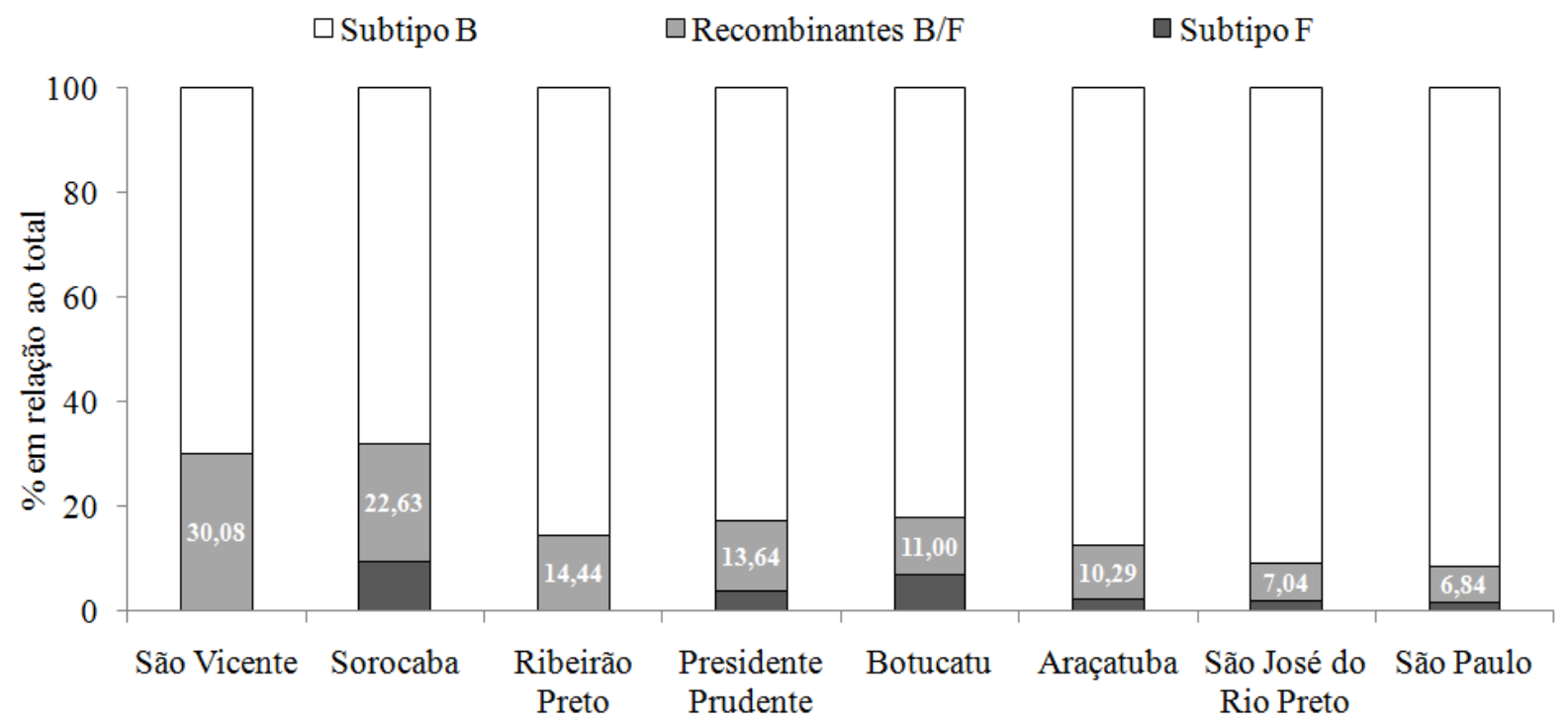

Figura 16- Frequência de recombinantes BF, e dos subtipos $\mathrm{F}$ e $\mathrm{B}$ nos diferentes pontos de coleta do VGDN. A classificação em subtipos B e F foi baseada na ausência de recombinação intragênica e na concordância entre os subtipos para os genes disponíveis de cada paciente. Os municípios estão organizados de acordo com a frequência de ocorrência de formas recombinantes BF.

A genealogia inferida a partir do gene env aponta para uma concentração de amostras recombinantes com env F na região de Sorocaba e, em menor escala na região de Presidente Prudente (Figura 18). Isto contrasta com o padrão de dispersão observado para os outros recombinantes como, por exemplo, as CRFs 28 e 29 que, apesar de concentradas na região litorânea do Estado, são também encontradas em outras cidades do Estado. Esse contraste pode derivar de uma origem mais recente destes recombinantes que, portanto, não teriam tido tempo suficiente para se disseminarem para outras regiões do Estado. De fato, o ano do primeiro resultado positivo para HIV na maioria dos casos analisados em Sorocaba é, em geral, mais recente do que em outras regiões, corroborando a hipótese de uma epidemia mais recente. Interessantemente, este agrupamento de recombinantes com env $\mathrm{F}$ também é observado na genealogia inferida com as sequências do gene pol classificadas como subtipo 
B, entretanto, como dito anteriormente, algumas destas sequências de env subtipo $\mathrm{F}$ da região de Sorocaba não possuíam o gene pol (Figura 19). Todos os grupos de amostras do subtipo B presentes nas genealogias de gag e env foram observados na genealogia do gene pol (W1, W2 e W3).

Preocupantemente, em todas as genealogias foram observadas amostras de recombinantes dispersas entre sequências "puras", sugerindo que além das CRFs BF muitas URFs estão presentes na epidemia do Estado de São Paulo, e dependendo das suas características adaptativas podem ser transmitidas eficientemente e emergirem na epidemia como uma nova CRF. Mais preocupante ainda é o fato de que, para que estes eventos ocorram, é estritamente necessário que um indivíduo esteja infectado por duas linhagens distintas simultaneamente ou sequencialmente. Caso ocorra simultaneamente, os dois vírus devem ser capazes de se estabelecer no paciente de maneira que uma única célula seja infectada pelas duas linhagens (STEAIN et al., 2004). A segunda possibilidade, historicamente tida como mais rara, visto que o evento de transmissão ocorre depois que o paciente já apresenta algum tipo de resposta imunológica contra a primeira variante, tem implicações sérias no desenvolvimento de estratégias vacinais, já que a infecção por uma linhagem não confere proteção contra uma nova infecção. Apesar de sempre ter sido considerada menos frequente, diversos trabalhos têm demonstrado que a infecção crônica por HIV não confere proteção contra superinfecção (JOST et al., 2002; RAMOS et al., 2002; FANG et al., 2004; KOZACZYNSKA et al., 2007; PIANTADOSI et al., 2007; STREECK et al., 2008). Portanto, estes resultados apontam para a necessidade de estudos que determinem a frequência de coinfecção/superinfeção em paciente residentes em municípios com alta frequência de recombinantes como, por exemplo, Sorocaba, além de estudos que determinem os possíveis fatores associados com a reinfecção. 


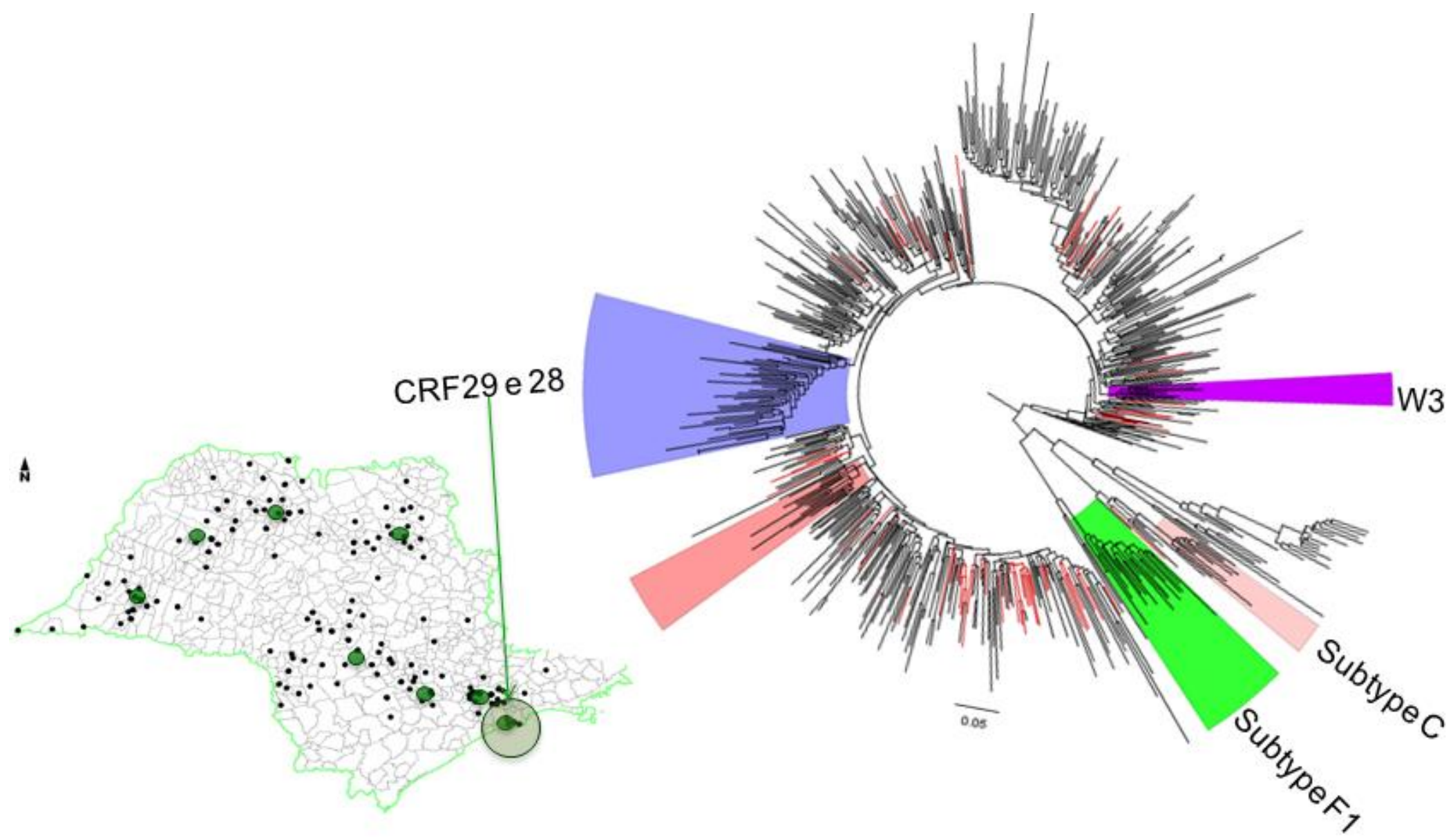

Figura 17- Reconstrução filogenética por máxima verossimilhança a partir de sequências do gene gag, incluindo sequências de referência dos subtipos B, D, C, F, G, H, e CRF01_AE. As amostras de gag subtipo B relacionadas às CRF28_BF e CRF29_BF formam o clado destacado em azul, e foram coletadas em sua maioria na região de São Vicente, circulo verde maior apontado pela seta. Outros dois clados pertencentes ao subtipo B estão destacados em roxo (W3) em rosa (W2), os quais são formados por amostras coletadas na região de Presidente Prudente. Os ramos em vermelho representam amostras recombinantes, em outros genes. Não foi possível observar um padrão para a as sequencias gag subtipo C ou F. O comprimento dos ramos é dado em números de substituições por sítios. A árvore foi enraizada num ponto médio apenas para facilitar a vizualização. Mapa gerado pelo Dr. Reinaldo Paul Pérez Machado (Universidade de São Paulo, Faculdade de Filosofia Letras e Ciências Humanas, Departamento de Geografia). 


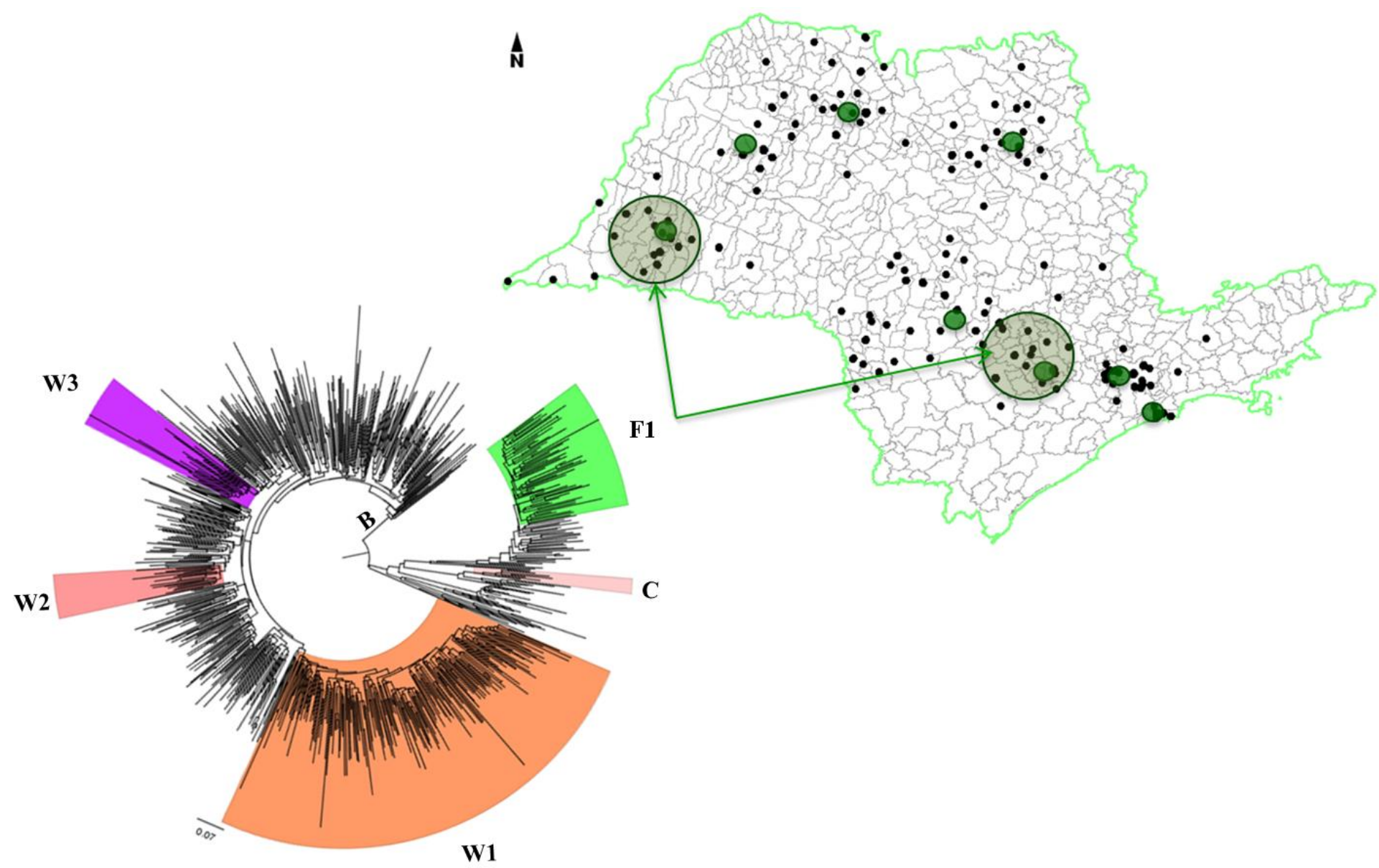

Figura 18- Reconstrução filogenética por máxima verossimilhança a partir das sequências do gene env, incluindo sequências de referência dos subtipos B, D, C, F, G, H, e CRF01_AE. Amostras do subtipo F são destacadas em verde e, como apresentado no mapa, foram encontradas principalmente em pacientes da região de Sorocaba e de Presidente Prudente. O grupo W1 é formado em sua maioria por sequências de pacientes residentes na região noroeste do estado (Araçatuba e São José do Rio Preto). Os grupos W2 e W3, como descritos na figura 16, são coletadas na região de Presidente Prudente. O comprimento dos ramos é dado em números de substituições por sítios. A árvore foi enraizada num ponto médio apenas para facilitar a vizualização. Mapa gerado pelo Dr. Reinaldo Paul Pérez Machado (Universidade de São Paulo, Faculdade de Filosofia Letras e Ciências Humanas, Departamento de Geografia). 


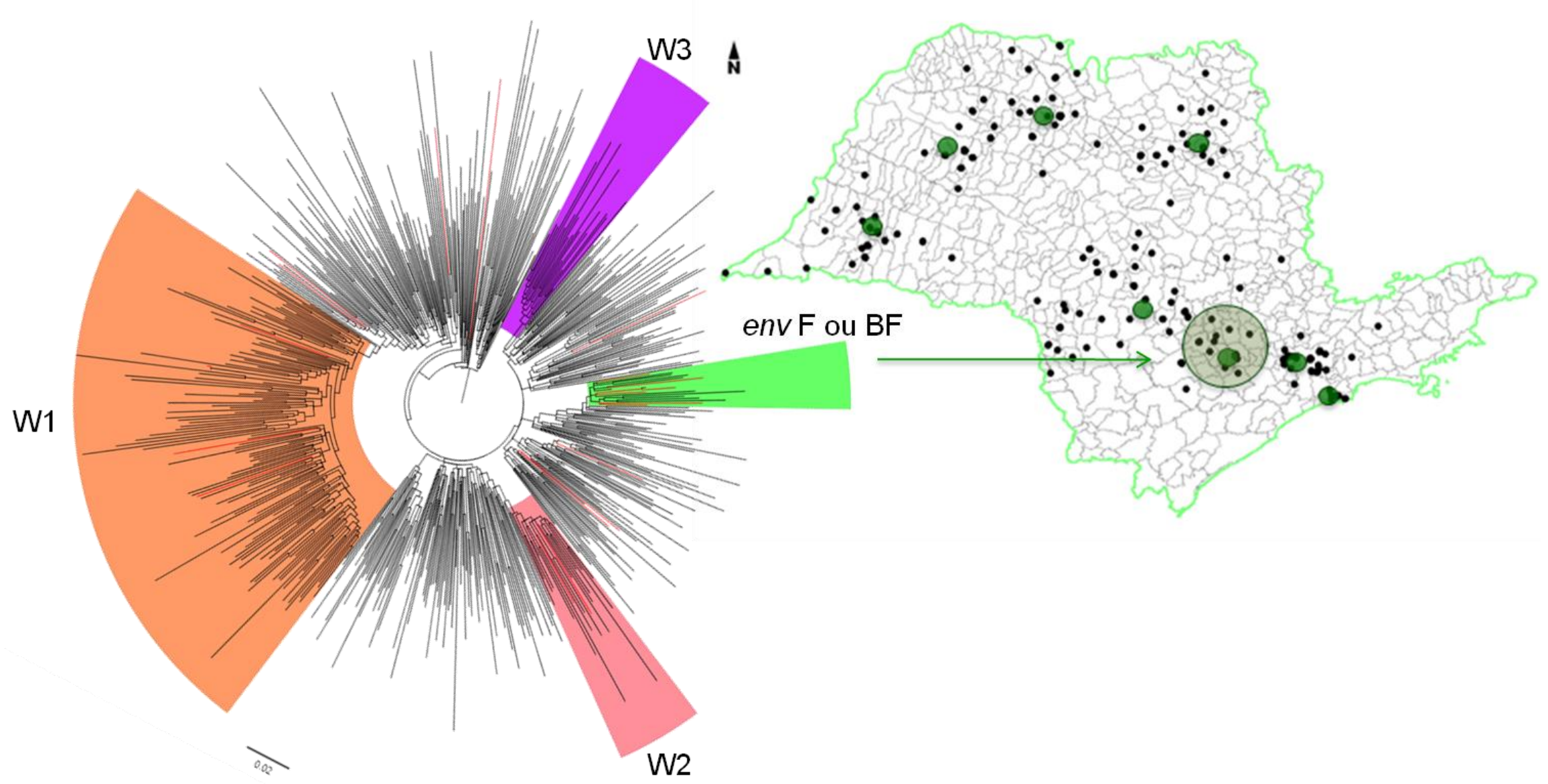

Figura 19- Reconstrução filogenética por máxima verossimilhança a partir das sequências de pol (pro-pol) do subtipo B. Assim como nas genealogias inferidas com os genes gag e env, os clados $\mathrm{W} 2 \mathrm{e} \mathrm{W} 3$ podem ser observados, assim como o clado W1 observado somente em env. Os ramos em vermelho representam as amostras recombinantes para as demais regiões do genoma. Amostras de pol B mas com env subtipo F ou BF estão destacadas em verde e, como apresentado no mapa, foram encontradas principalmente na região de Sorocaba, confirmando o padrão obtido com as sequências de env subtipo F. O comprimento dos ramos é dado em números de substituições por sítios. A árvore foi enraizada num ponto médio apenas para facilitar a vizualização. Mapa gerado pelo Dr. Reinaldo Paul Pérez Machado (Universidade de São Paulo, Faculdade de Filosofia Letras e Ciências Humanas, Departamento de Geografia). 


\subsubsection{Perfil de recombinação dos genes gag, pol e env}

Do total de 152 amostras BF, 35 foram classificadas como recombinantes por apresentaram discordância de subtipo entre os genes, ou seja, embora tenha sido possível determinar a ocorrência de recombinação, o ponto de quebra não estava inserido dentro dos genes analisados. Dentre as 113 amostras restantes, 101 apresentaram pontos de recombinação dentro do gene $p o l$, sete dentro de gag e cinco dentro de env. Devido a diferença no número de eventos de recombinação entre o gene pol e os demais genes, os resultados estão mostrados de formas diferentes. Para pol, um resumo dos pontos de recombinação pode ser observado na figura 20 , onde é possível observar a frequência de ocorrência de cada subtipo ao longo de todo o gene, dividido em janelas de 50 nt. Desse perfil é possível notar que a maioria dos recombinantes apresentou uma protease do subtipo $\mathrm{F}$ independente do perfil de recombinação no restante dos genes, ou seja, foram encontrados diferentes perfis de recombinação onde a protease $\mathrm{F}$ foi mais frequente. Exemplos destes perfis podem ser observados na figura 21.

Curiosamente, das cinco CRFs_BF descritas no Brasil apenas uma apresentou protease B (CRF39) (DE SA FILHO et al., 2006; GUIMARAES et al., 2008; SANABANI et al., 2010). Este mesmo padrão pode ser observado em recombinantes BF presentes em outros países da América Latina (CRF12_BF, CRF17_BF, CRF44_BF) (CARR et al., 2001; DELGADO et al., 2010) e da Europa (CRF47_BF) (FERNANDEZ-GARCIA et al., 2010). Dado que algumas destas CRFs apresentam pontos de recombinação similares em determinadas regiões do genoma, a recorrência de proteases $\mathrm{F}$ poderia ser resultado de um único evento de recombinação com posterior diversificação. Entretanto, uma grande parte destas CRFs não possui origem comum e são produtos de diferentes eventos de recombinação. Portanto, este perfil pode indicar que variantes com protease $\mathrm{F}$ apresentam maior vantagem adaptativa. Independente dos fatores envolvidos nesse processo, estes resultados deixam claro que a região sequenciada do gene pol é um hotspot de ocorrência de recombinação. Embora menos acentuadamente, essa característica de pol como importante sítio de recombinação foi observada também por Zhang et al. (2010) ao analisar 56 genomas completos de recombinantes BF disponíveis em bancos de dados públicos. Considerando o número total de sequências analisadas para cada gene, pol ainda se destaca com proporção elevada de recombinação intragênica (101/753) em relação aos demais, gag (7/556) e env $(5 / 763)$. 


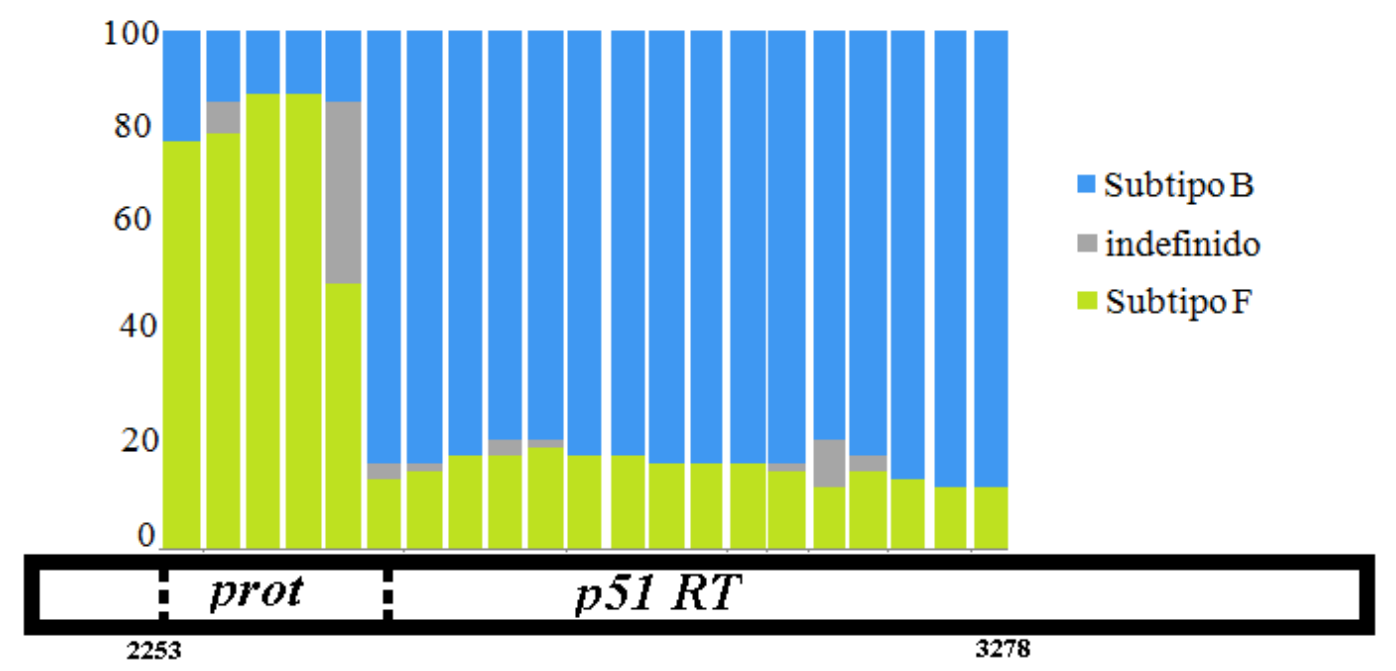

Figura 20- Resumo dos eventos de recombinação para o gene pol de 101sequências com evidência de recombinação intragênica. Cada barra corresponde a uma janela de $50 \mathrm{nt}$ com a frequência observada de cada subtipo. O subtipo B é representado em azul, o subtipo F em verde e a indeterminação de subtipo devido à incerteza no ponto de recombinação é representada em cinza. É possível observar que a grande maioria das formas recombinantes $\mathrm{BF}$ mantêm a protease do subtipo $\mathrm{F}$ e o restante do gene do subtipo $\mathrm{B}$. As coordenadas são apresentadas em relação ao HXB2.

Como é possível observar com relação ao gag (Figura 22), 2 de suas amostras são formas recombinantes únicas (URFs), enquanto as demais se dividem em dois grupos com pontos de recombinação distintos: (i) 0870BO_gBF, 0911BO_gBF e 1025SO_gBFpFeF (914 $\pm 25,915 \pm 22$ e $915 \pm 22$, em relação ao HXB2), (ii) 0376SP_gBF e 0386SP_gBF (1223 \pm 1 e $1225 \pm 3$ ). Em ambos os casos as amostras são provenientes de pacientes que residem em municípios próximos na região de Sorocaba e na região metropolitana de São Paulo respectivamente, o que sugere as amostras de cada grupo compartilhem uma origem comum. Com relação ao gene env (Figura 23) apenas duas URFs foram observadas, enquanto as demais amostras compartilharam o mesmo ponto de quebra $(7182 \pm 59,7197 \pm 34$ e $7187 \pm$ 18, em relação ao HXB2).

Além dos eventos de recombinação entre os subtipos B e F, foi ainda observado um triplo recombinante, $\mathrm{BCF}$, o qual apresenta o gene gag proveniente de subtipo B e o gene pol recombinante entre B, C e F (Figura 24). Muito provavelmente esta forma corresponde a uma segunda geração de recombinantes, cujos parentais foram provavelmente uma das CRF28/29_BF e a CRF31_BC. O envolvimento das CRF28/29 é suportado pela genealogia do gene gag, visto que para a sequência de gag para a amostra 1471PP se agrupou com as sequências classificadas como CRF28/29_BF. O envolvimento da CRF31_BC é evidenciado na figura 23, onde é possível observar que além do ponto de recombinação entre os subtipos C 
e F, posição $2575 \pm 33$, uma região de incerteza para o subtipo B pode ser observado na posição $3038 \pm 178$. Esta região coincide com o fragmento B descrito para a CRF31_BC, conforme mostrado na figura 22. Apesar de formas recombinantes complexas como esta, envolvendo mais de dois subtipos, nunca terem sido descritas no Brasil, um caso isolado foi identificado na Argentina (PANDO et al., 2006). Entretanto, é possível que a frequência destes eventos esteja aumentando na população devido a recente expansão dos subtipos $\mathrm{C}$ e CRF31_BC para a região Sudeste (BRIGIDO et al., 2010).

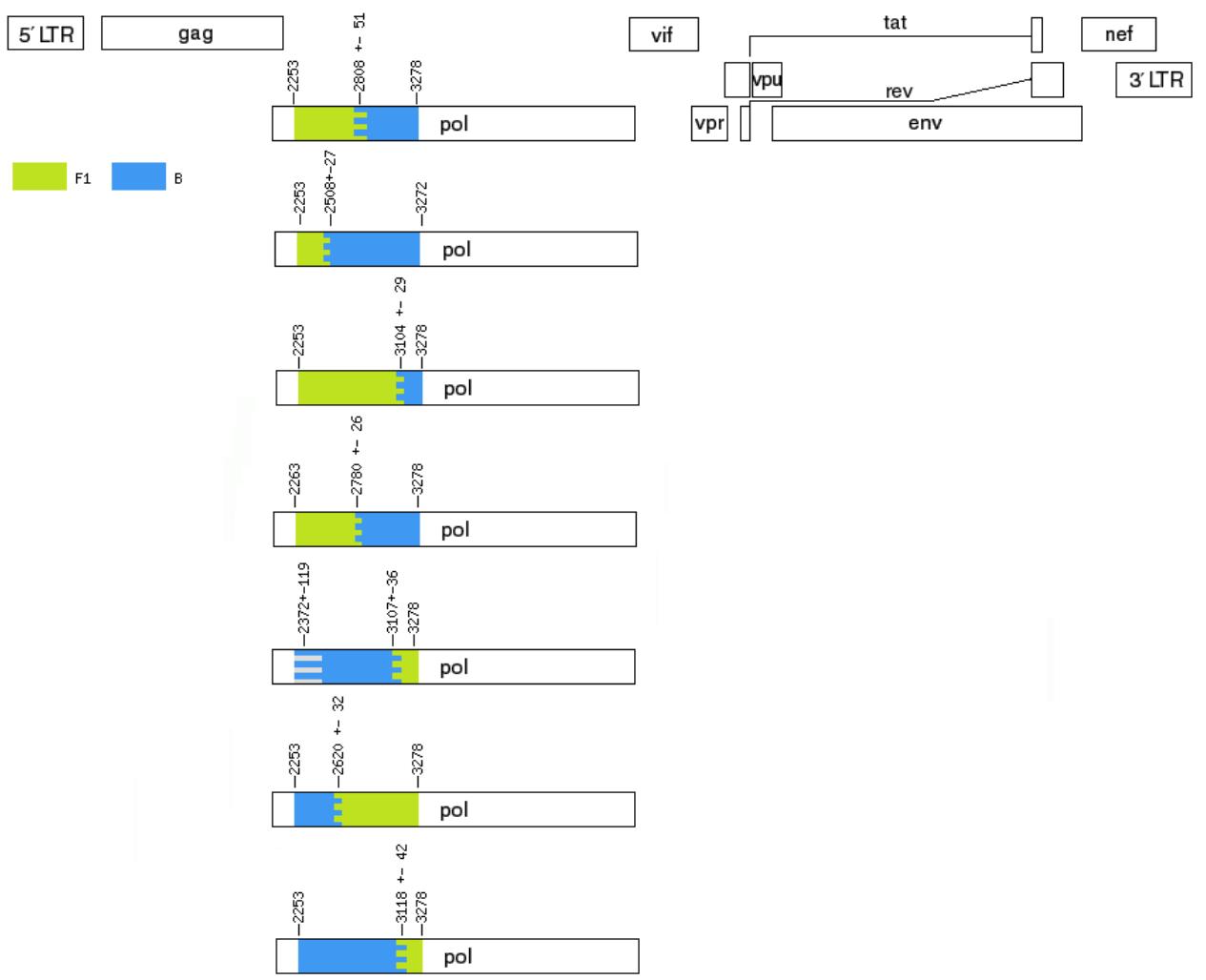

Figura 21- Exemplos dos diferentes pontos de recombinação encontrados no gene pol. As regiões hachuradas correspondem a incerteza na inferência do ponto de recombinação. As coordenadas são apresentadas em relação ao HXB2. 


\section{UTR}

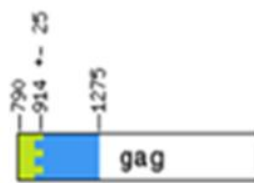

0870BO_gBFeF
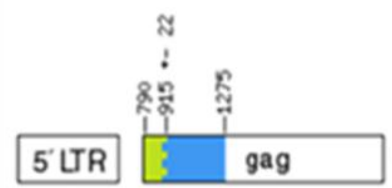

0911BO_gBFeF

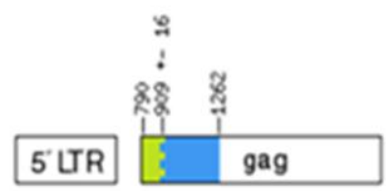

1024SO_gBFpFeF

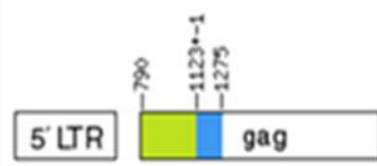

0376SP_gBF

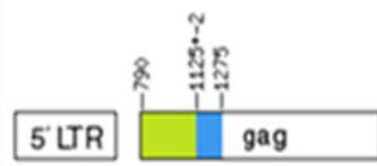

0386SP_gBFe

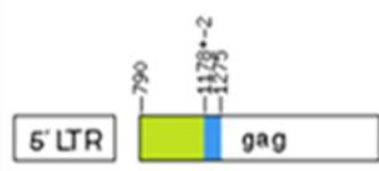

0902BO_gBFeF

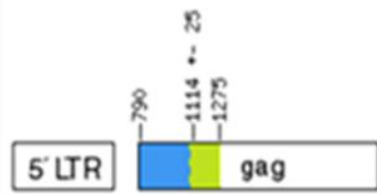

1012S0_gBFpBFeF

Figura 22- Eventos de recombinação, observados no gene gag entre subtipos B e F. Das 556 sequências geradas apenas 7 apresentaram pontos de recombinação nesta região. As amostras 0870BO_gBFeF, 0911BO_gBFeF e 1025SO_gBFpFeF apresentaram o mesmo ponto de recombinação $(914 \pm 25,915 \pm 22$ e $915 \pm 22$, respectivamente), bem como as amostras 0376SP_gBF e 0386SP_gBF (1223 \pm 1 e $1225 \pm 3)$. As demais amostras são formas recombinantes únicas (URFs). As coordenadas são apresentadas em relação ao HXB2. 

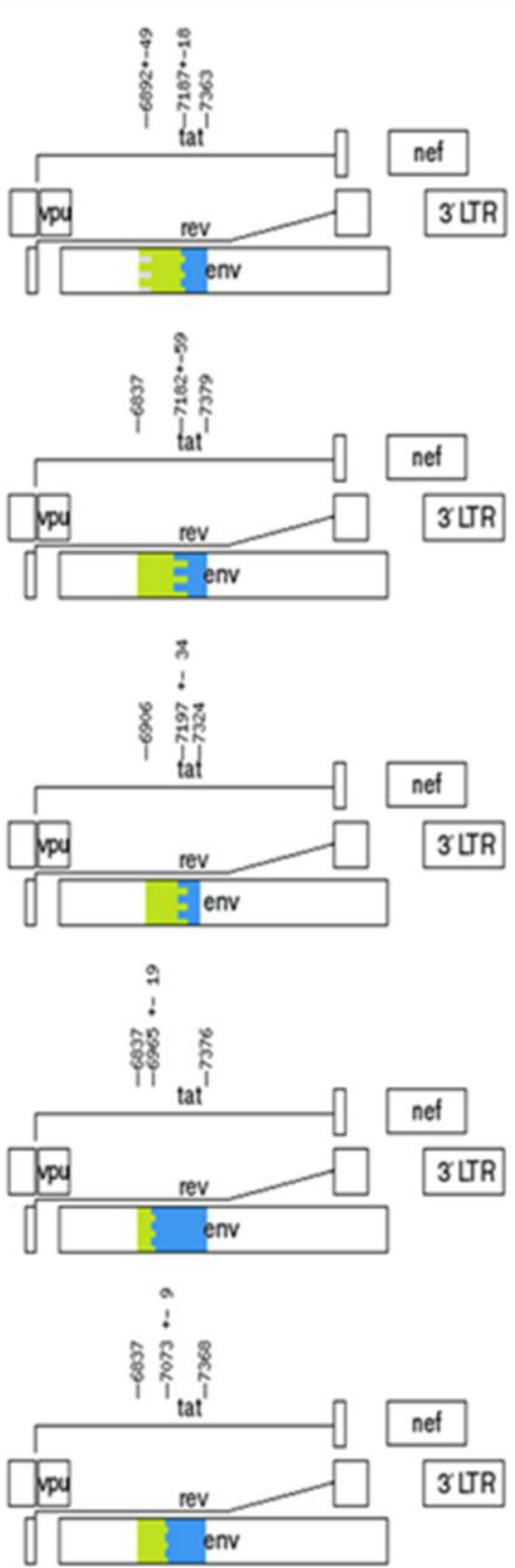

F1
1102SO_eBF

1138SO_gBpBeBF

1139SO_pBeBF

1018SO_eBF

1111SO_pBeBF

Figura 23- Eventos de recombinação, observados no gene env, entre subtipos B e F. Das 763 sequências geradas apenas 5 apresentaram pontos de recombinação nesta região. As amostras 1102SO_eBF, 1138SO_eBF e 1139SO_pBeBF apresentaram o mesmo ponto de recombinação $(7187 \pm 18,7182 \pm 59$ e $7197 \pm 34$, respectivamente. As demais amostras são formas recombinantes únicas (URFs). As regiões hachuradas correspondem a incerteza na inferência do ponto de recombinação. As coordenadas são apresentadas em relação ao HXB2. 


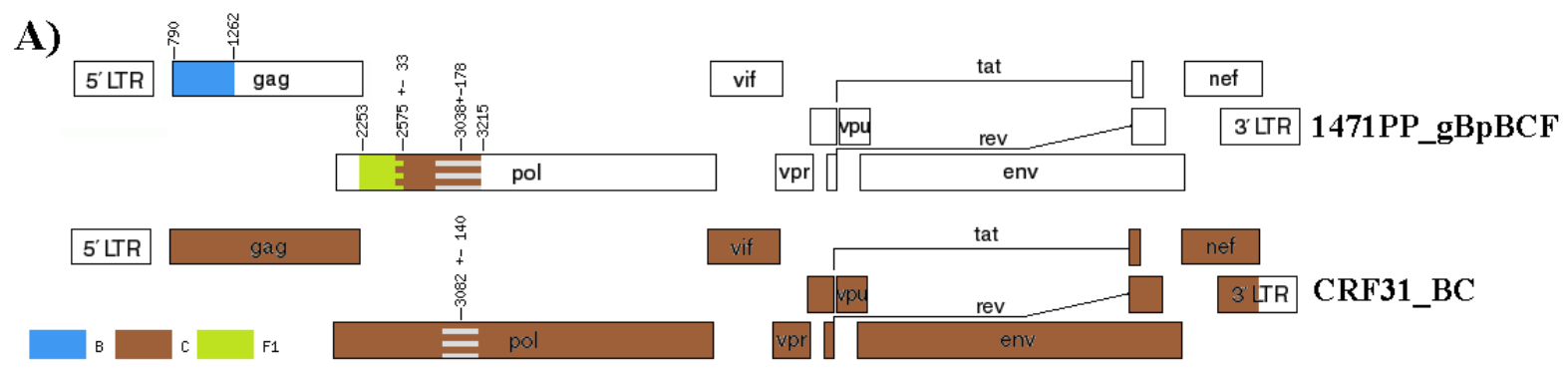

B)
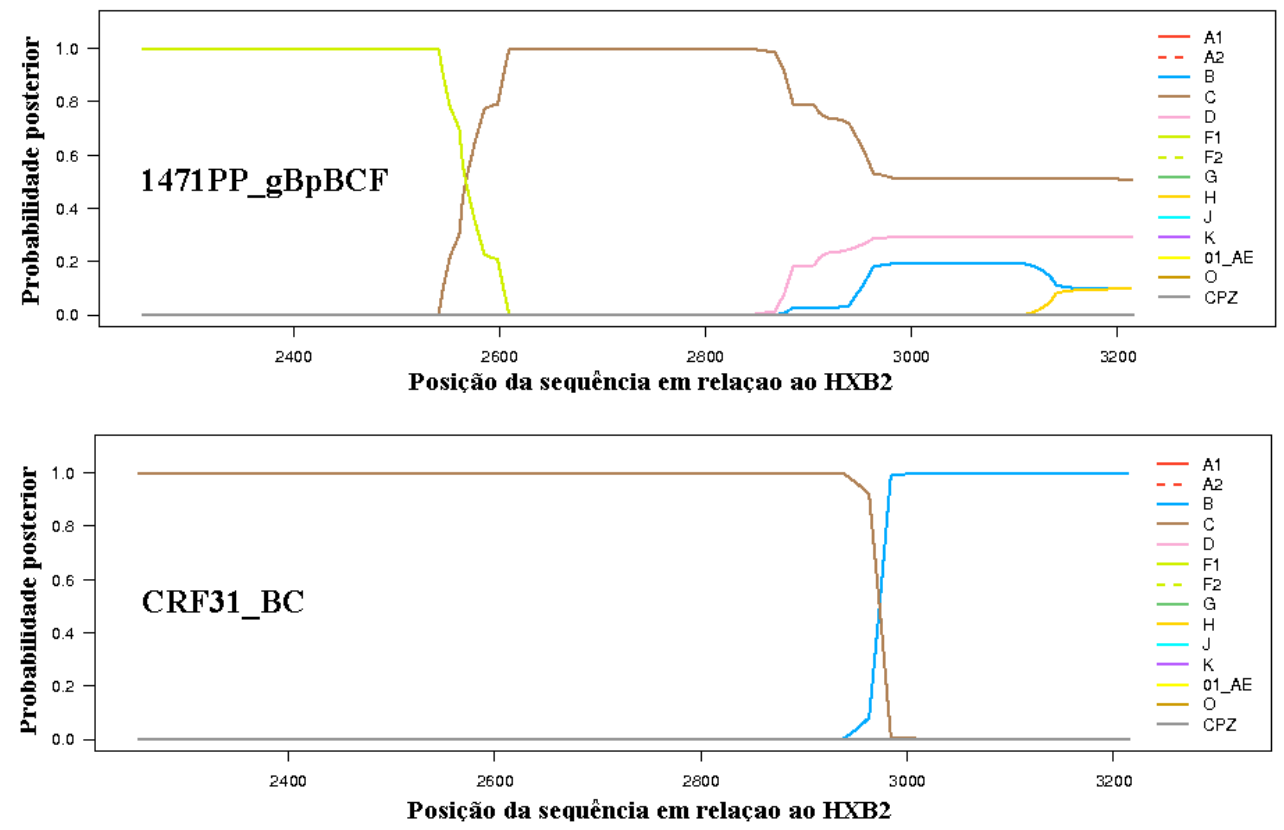

Figura 24- Resultado da análise de recombinação com o programa jpHMM para o gene pol da amostra 1471PP, que apresenta regiões dos subtipos B, C e F. A) Esquema do genoma do HIV-1 mostrando os pontos de recombinação entre os subtipos F e C na posição 2575 \pm 33 e uma região de incerteza (área hachurada) na porção final do gene (3038 \pm 178$)$. Abaixo do perfil da amostra 1471PP é apresentado o perfil de recombinação da CRF31_BC, a qual é caracterizada por um pequeno fragmento do subtipo B na região $3082 \pm 140$. B) Gráfico mostrando as variações na probabilidade posterior para cada subtipo ao longo de toda a sequência, onde é possível observar a redução na probabilidade posterior do subtipo C após a região 2800, assim como na CRF31_BC, o que sugere que uma das formas parentais foi a CRF31. As coordenadas são apresentadas em relação ao HXB2. 


\subsection{CARACTERIZAÇÃO DO GENE DA INTEGRASE}

Conforme o item 3.2 (Material e Métodos), 159 pacientes coletados durante a execução do projeto VGDN, foram selecionados para o sequenciamento adicional do gene da integrase. Estes pacientes foram escolhidos com base no histórico de tratamento antirretroviral (PI, inibidores de protease; NRTI, inibidores da transcriptase reversa análogos de nucleosídeos e NNRTI, inibidores da transcriptase reversa não-análogos de nucleosídeos). Como descrito na tabela 7, dos 159 pacientes sequenciados 25 nunca receberam nenhum tipo de tratamento antirretroviral e 134 já haviam sido submetidos a pelo menos um esquema de tratamento antirretroviral. No grupo de pacientes não tratados apenas uma amostra apresentou mutações de resistência, enquanto no outro grupo 34 pacientes apresentaram resistência. É importante ressaltar que os inibidores de integrase foram liberados pela Agência Nacional de Vigilância Sanitária (ANVISA) no início de 2008 e o seu uso é recomendado apenas em pacientes com falha terapêutica, e que apresentem mutações de resistência para no mínimo uma droga de cada uma das classes descritas anteriormente. Portanto a escolha destes pacientes foi voltada àqueles que já foram submetidos a ao menos algum tipo de tratamento antirretroviral.

TABELA 7- Distribuição dos pacientes de acordo com o perfil de tratamento (não tratados e tratados) e ocorrência de resistência aos inibidores de protease e transcriptase reversa.

\begin{tabular}{cccc}
\hline & \multicolumn{3}{c}{ Números de pacientes com resistência } \\
\cline { 2 - 4 } Inibidores & Não tratados & Tratados & Total \\
\hline PI $^{1}$ & & 1 & 1 \\
NRTI $^{2}$ & 1 & 3 & 3 \\
NNRTI $^{3}$ & & 10 & 11 \\
PI e NRTI & & 5 & 5 \\
P1 e NNRTI & & 11 & - \\
NRTI e NNRTI & & 4 & 11 \\
PI, NRTI e NNRTI & $1 / 25$ & $34 / 134$ & 4 \\
Total (resistentes/total) & &
\end{tabular}

\footnotetext{
${ }^{1}$ Inibidores de protease

${ }^{2}$ Inibidores da transcriptase reversa análogos de nucleosídeos

${ }^{3}$ Inibidores da transcriptase reversa não análogos de nucleosídeos
} 
Após a seleção dos pacientes, a reação de amplificação do gene da integrase foi realizada. A figura 25 apresenta o resultado da amplificação para uma das amostras. Como é possível observar foi obtido um fragmento de aproximadamente $1200 \mathrm{pb}$, dos quais $864 \mathrm{pb}$ foram sequenciados como descrito anteriormente (seção 3.6). Na tabela 7 estão descritos os resultados das análises de determinação de subtipos e de recombinação. Do total de integrases seqüenciadas, 130 foram classificadas como subtipo B, 17 como subtipo F, 11 como recombinantes $\mathrm{BF}$ e uma como subtipo C. Entretanto, levando em conta os demais genes disponíveis para estes pacientes, estas amostras foram reclassificadas, e 109 pacientes só apresentaram genes do subtipo B, 7 apresentaram apenas genes do subtipo F, 1 do subtipo C e 42 pacientes foram classificados como recombinantes BF. Como esperado, o sequenciamento adicional deste gene permitiu a identificação de mais 10 amostras recombinantes, portanto, o número de pacientes infectados com formas recombinantes BF descrito no item 4.1 aumentou de 152 para 162 casos. É muito importante destacar que estes resultados revelam que o número de recombinantes é normalmente subestimado em estudos baseados no sequenciamento de apenas um gene. Portanto, necessita-se de sequenciamento da maior quantidade possível de regiões do genoma viral para aumentar a acurácia na quantificação de recombinantes inter-subtipos existentes numa população, como no Estado de São Paulo e em outras regiões brasileiras onde múltiplos subtipos cocirculam (TANURI et al., 1999; VICENTE et al., 2000; SOARES et al., 2005; CABRAL et al., 2006; SANABANI et al., 2006; SUCUPIRA et al., 2007; VERAS et al., 2007; DE SOUZA et al., 2008; RABONI et al., 2010).

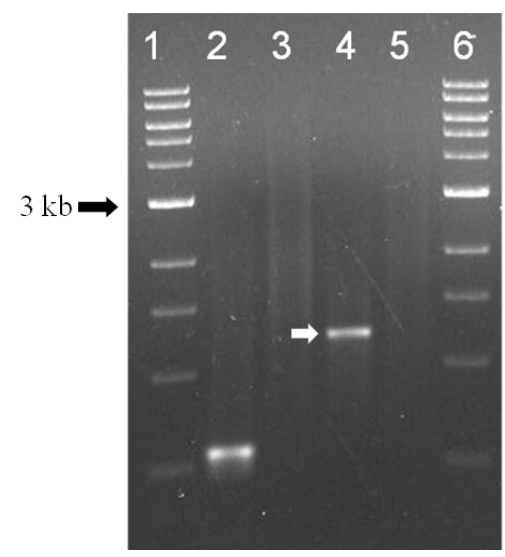

Figura 25- Segunda etapa da PCR do gene da integrase. Nas linhas 1 e 6 marcador de $1 \mathrm{~kb}$ (New England Bioloabs). Na coluna 2 controle da reação utilizando iniciadores para o gene gag $(\cong 500 \mathrm{pb})$. Na coluna 4 o fragmento esperado de $\cong 1200 \mathrm{pb}$ para o gene da integrase, amplificado com os iniciadores descritos na Tabela 6. Nas colunas 3 e 5 controle de reação sem DNA. 
TABELA 8-Distribuição dos subtipos entre as 159 sequências de integrase de pacientes coletados durante a execução do projeto VGDN.

\begin{tabular}{cc}
\hline Subtipo & Número de amostras \\
\hline B & $130(81,8 \%)$ \\
F & $17(10,7 \%)$ \\
BF & $11(6,9 \%)$ \\
C & $1(0,6 \%)$ \\
\hline Total & 159 \\
\hline
\end{tabular}

Após a exclusão das 11 sequências com evidência de recombinação intragênica, foi construído um conjunto de dado (dataset) para as reconstruções filogenéticas, com as 148 sequências descritas anteriormente além de 315 sequências de integrases, sem evidência de recombinação intragênica, de amostras brasileiras disponíveis no GENBANK (ANEXO A), num total de 463 taxa e 864 pb. Este dataset foi utilizado na reconstrução filogenética com o programa GARLI descrito na seção 3.1.1. A figura 26 apresenta a filogenia com os subtipos B, C e F, onde é possível observar que algumas amostras do subtipo B formaram agrupamentos antes observados (e.g., W1 e W2), reafirmando o padrão de distribuição de algumas amostras do subtipo B anteriormente apresentado (Figuras 17 a 19). Em contraste, a maioria das amostras do subtipo $\mathrm{F}$ está dispersa entre as demais sequências do GENBABK, com exceção de um pequeno agrupamento de amostras da região de Sorocaba. Entretanto, o que mais chama a atenção nestes dados é a distribuição das amostras recombinantes, que com exceção do agrupamento formado pela CRF46_BF (SANABANI et al., 2010), apresentaramse dispersas na árvore. Este padrão poderia ser explicado pela menor variabilidade genética observada no gene da integrase (LATAILLADE; CHIARELLA; KOZAL, 2007), o que dificultaria a reconstrução da verdadeira história filogenética destas sequências. Entretanto, apesar da menor diversidade encontrada no gene da integrase, alguns agrupamentos foram consistentes com as genealogias gag, pol (pro-pol) e env. Alternativamente, este padrão poderia ser resultado de diferentes eventos de coinfecção dando origem a recombinantes. Em outras palavras, estes recombinantes podem ter surgido a partir de diferentes eventos, o que levaria a formação de formas recombinantes únicas, as quais têm sido cada vez mais observadas entre os recombinantes BF (SA FILHO et al., 2005; SANABANI et al., 2006; GUIMARÃES et al., 2010; ZHANG et al., 2010). O perfil de recombinação das 11 sequências de integrases recombinantes corrobora este cenário, visto que muitas delas apresentaram pontos de recombinação distintos e foram classificadas como URFs (Figura 27). Entretanto, aqui não cabem generalizações, visto que pontos de recombinação 
compartilhados foram observados no gene da integrase e nos genes descritos anteriormente (Figuras 17-19 e Figura 27).

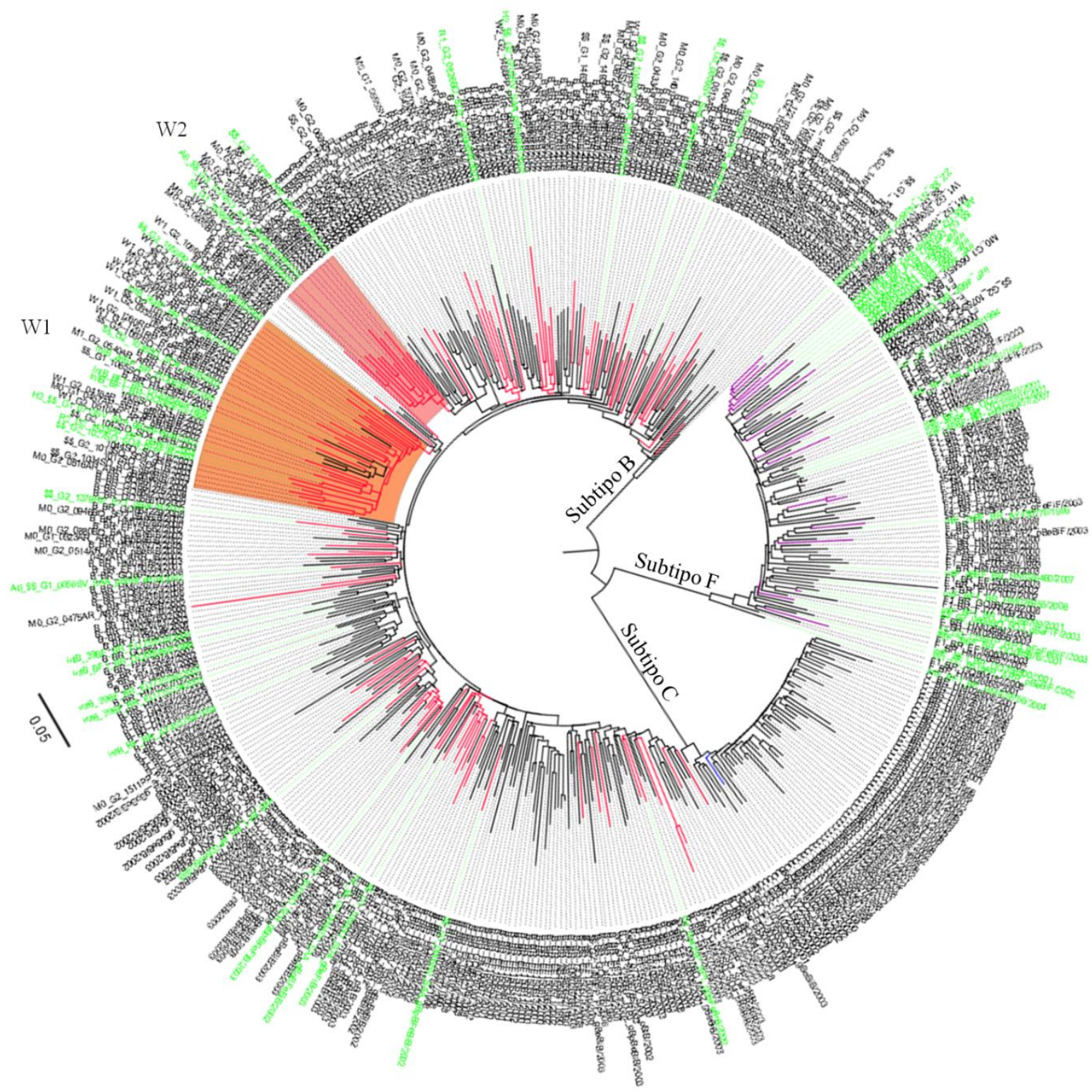

Figura 26- Reconstrução filogenética por máxima verossimilhança a partir de 463 sequências do gene da integrase. Os ramos referentes às amostras sequenciadas neste trabalho estão representados em vermelho (integrases do subtipo B), roxo (integrases do subtipo F) e em azul (1 amostra do subtipo C). O ramo das sequências provenientes do GENBANK estão representados em preto. As sequências pertencentes a vírus recombinantes, em outras regiões do genoma, estão destacadas em verde. O comprimento dos ramos é dado em números de substituições por sítios. A árvore foi enraizada num ponto médio apenas para facilitar a vizualização. 

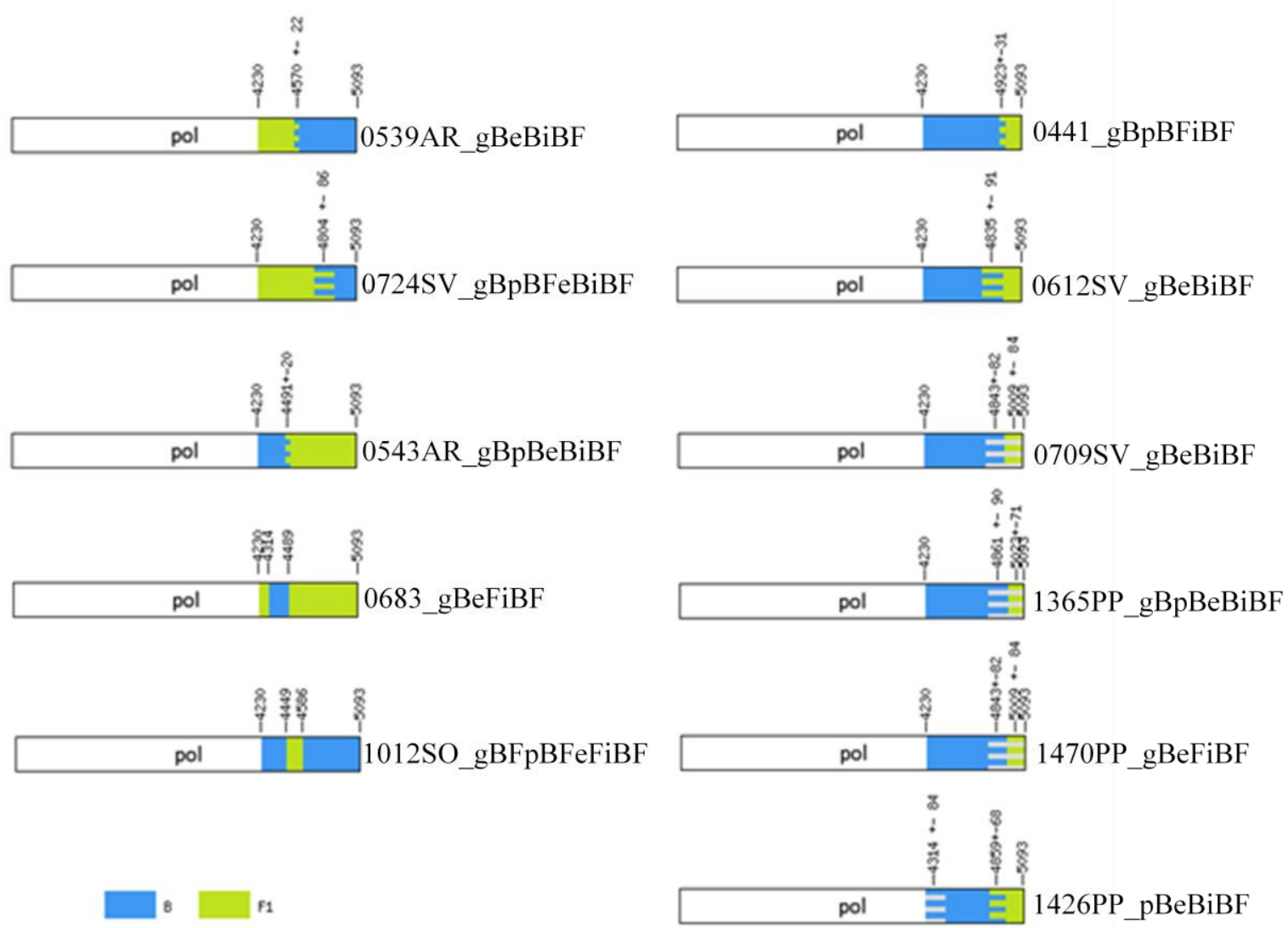

Figura 27- Eventos de recombinação observados no gene da integrase (864 pb), entre os subtipos B e F. Das 159 sequências geradas 11 apresentaram pontos de recombinação nesta região. As amostras $0441 \mathrm{AR}, 0612 \mathrm{SV}, 0708 \mathrm{SV}, 1365 \mathrm{RP}$ e 1470PP apresentaram o mesmo ponto de recombinação $(4923 \pm 31,4835 \pm 91,4843 \pm 82,4804 \pm 86,4861 \pm 90$ e $4850 \pm 76$, respectivamente), entretanto apresentaram discordâncias em outras regiões do genoma. As regiões hachuradas correspondem a incerteza na inferência do ponto de recombinação. As demais amostras apresentaram pontos de recombinação distintos. As coordenadas são apresentadas em relação ao HXB2. 


\subsubsection{Perfil de resistência genotípica ao raltegravir}

O estudo da ocorrência dos polimorfismos genéticos presentes no gene da integrase associados à resistência a esta nova classe de inibidores é de grande importância para o planejamento de políticas públicas e na terapia antirretroviral. Fortuitamente, nenhum polimorfismo associado à resistência primária ao RAL (Y143R/C, Q148K/H/R, e N155H) foi encontrado dentre as amostras sequenciadas neste trabalho, assim como nos dois únicos trabalhos com este enfoque realizados no Brasil (PASSAES et al., 2009a; ARRUDA et al., 2010). Entretanto, a frequência de mutações secundárias foi razoavelmente elevada, com $38,4 \%$ (61/159) dos pacientes apresentando ao menos uma mutação, sendo que ao todo foram observadas 65 mutações (Tabela 9). O polimorfismo mais frequente foi o V151I (40/65), observado em 37 amostras do subtipo B e em três amostras de recombinantes (0539AR_gBeBiBF, 1012SO_gBFpBFeFiBF e 1365RP_gBpBeBiBF), as quais foram classificadas como subtipo B nesta região inicial da integrase (Figura 26). De fato, esta mutação de resistência secundária já havia sido descrita como polimórfica em sequências do subtipo B coletadas de pacientes não tratados com RAL (LATAILLADE; CHIARELLA; KOZAL, 2007; PASSAES et al., 2009a; ARRUDA et al., 2010). Entretanto, nas amostras do subtipo B do VGDN a frequência foi de 28,5\% (37/130), enquanto que nos trabalhos citados anteriormente variou de 10-23\%. É difícil prever o impacto deste polimorfismo no tratamento com RAL, uma vez que esta mutação é selecionada in vitro por alguns inibidores de integrase, mas não existem evidências de que ela reduza a suscetibilidade da integrase ao RAL (HAZUDA et al., 2004; MARKOWITZ et al., 2007; MCCOLL et al., 2007; LOW et al., 2009). A segunda mutação mais frequente foi a S230N, e apesar de não conferir resistência ao Raltegravir, confere resistência aos primeiros inibidores de integrase avaliados (LOW et al., 2009).

Três pacientes apresentaram mais de uma mutação minoritária de resistência, como o paciente 1094SO_gBpBeBiF que apresentou as mutações V54I, T97A e G163R, que de acordo com o algoritmo de interpretação de resistência fenotípica do HIV Drug Resistance Database de Stanford, conferem baixos níveis de resistência ao raltegravir (RAL). Estas mutações são selecionadas in vitro na presença de RAL, e frequentemente estão associadas com as mutações de resistência primária Y143R (T97A) e N155H (G163R) (MARKOWITZ et al., 2007; MALET et al., 2008; GOETHALS et al., 2010), e a presença do par T97AY143R reduz expressivamente a suscetibilidade ao RAL (REUMAN et al., 2010). Os outros dois pacientes apresentaram duas mutações secundárias, 1239RP_pBeBiB (T97A e V151I) e 
1370RP_pBeBiB (V54I, S230N), entretanto apenas o paciente 1239 pode apresentar algum nível de resistência ao RAL.

TABELA 9- Ocorrência de polimorfismos associados com resistência aos inibidores de integrase entre 159 pacientes amostrados durante o projeto VGDN.

\begin{tabular}{|c|c|c|c|c|}
\hline \multirow[b]{2}{*}{ Mutações } & \multicolumn{4}{|c|}{ Número de ocorrências } \\
\hline & Subtipo B & Subtipo F & Subtipo BF & Total \\
\hline V151I & 37 & - & 3 & $40 / 158$ \\
\hline S230 & 12 & - & - & $12 / 158$ \\
\hline G163R ${ }^{1}$ & 1 & 4 & - & $5 / 158$ \\
\hline V54 $I^{1}$ & 1 & 3 & - & $4 / 158$ \\
\hline L74M & 1 & & - & $1 / 158^{2}$ \\
\hline $\mathrm{T}^{9} \mathrm{~A}^{1}$ & 1 & 1 & - & $2 / 158$ \\
\hline E138D & 1 & - & - & $1 / 158$ \\
\hline Total & $54 / 130^{1}$ & $8 / 17^{1}$ & $3 / 11$ & $65 / 158^{1,2}$ \\
\hline
\end{tabular}




\subsection{ISOLAMENTO E CARACTERIZAÇÃO DE RECOMBINANTES BF}

\subsubsection{Isolamento viral, caracterização genômica e uso de correceptores}

Após a caracterização inicial das amostras do projeto VGDN, optamos por coletar o maior número possível de amostras de pacientes da cidade de São Vicente, pois como mostrado na figura 16, neste município foi observado a maior frequência de recombinantes com pontos de quebra similares a CRF28/29_BF. Pacientes dos municípios de Araçatuba, São Paulo e Ribeirão Preto também foram incluídos. Ao todo, foram selecionados 58 pacientes, portadores de formas recombinantes BF, um portador da CRF01_AE e alguns pacientes portadores de subtipos B. Entretanto, alguns destes pacientes já haviam falecido, alguns não aceitaram participar do estudo, e outros agendaram a coleta e não compareceram. Desta maneira apenas 36 pacientes foram amostrados (Tabela 10). Todas estas amostras foram submetidas ao co-cultivo e avaliadas para a produção de $\mathrm{p} 24$, ao final foram obtidos isolados primários para 10 amostras, destacadas em cinza na tabela 10 .

A caracterização do genoma e do uso de coreceptores destes isolados está descrita em detalhes no artigo Characterization of primary isolates of HIV-1 CRF28_BF, CRF29_BF and unique BF recombinants circulating in São Paulo, Brazil (ANEXO B). No entanto, um resumo dos resultados obtidos será apresentado.

Após a confirmação do isolamento, o estoque para cada uma destas amostras foi preparado e armazenado em $\mathrm{N}_{2}$ liquido. O DNA dos PBMCs provenientes da etapa de produção dos estoques foi utilizado na reação de amplificação do genoma proviral. Como descrito na seção 3.3.1, foram utilizadas duas estratégias PCR, uma baseada na amplificação de um único fragmento, e outra em três fragmentos menores com sobreposição, o resultado da amplificação para cada uma das estratégias é mostrado na figura 28. Uma etapa importante neste processo foi a diluição do DNA molde, visto a amplificação de fragmentos longos em HIV é extremamente prejudicada pela presença de provírus defectivos com deleções, as quais são preferencialmente amplificadas devido ao menor tamanho, inibindo ou diminuindo a eficiência da reação (EDMONSON e MULLINS, 1992). 
TABELA 10- Dados dos pacientes coletados e resultados do isolamento viral. As amostras positivas para o isolamento viral estão destacadas em cinza.

\begin{tabular}{|c|c|c|c|c|c|}
\hline ID & Sexo & Município & Subtipo VGDN & Carga Viral $^{2}$ & Isol. Viral \\
\hline 8 & $\mathrm{~F}$ & São Paulo & $\mathrm{pBx}$ & 595 & + \\
\hline 13 & M & São Paulo & $\mathrm{pB}$ & 4530 & - \\
\hline 18 & M & São Paulo & CRF_28/29 & <Lim.Mín & - \\
\hline 63 & M & São Paulo & CRF_28/29 & 45.600 & + \\
\hline 108 & M & São Paulo & $\mathrm{pBeB}$ & 166.000 & - \\
\hline 216 & $\mathrm{~F}$ & Rib. Preto & CRF_28/29 & 925 & - \\
\hline 220 & $\mathrm{~F}$ & Rib. Preto & CRF_28/29 & 7.620 & - \\
\hline 257 & $\mathrm{~F}$ & Rib. Preto & $\mathrm{pBF}$ & 13.650 & - \\
\hline 264 & M & Rib. Preto & CRF_28/29 & 22.000 & + \\
\hline 341 & $\mathrm{~F}$ & Rib. Preto & CRF_28/29 & 54.500 & + \\
\hline 440 & M & Araçatuba & $\mathrm{gBpB}$ & 70.378 & - \\
\hline 441 & $\mathrm{~F}$ & Araçatuba & $\mathrm{gBpBFeB}$ & 70.413 & - \\
\hline 471 & M & Araçatuba & $\mathrm{pBeB}$ & 70.290 & - \\
\hline 483 & M & Araçatuba & CRF_28/29 & 76.344 & - \\
\hline 495 & M & Araçatuba & CRF01_AE & 74.018 & - \\
\hline 614 & M & São Vicente & CRF_28/29 & <Lim.Mín & + \\
\hline 632 & M & São Vicente & $\mathrm{gBpB}$ & 150.347 & + \\
\hline 636 & $\mathrm{~F}$ & São Vicente & $\mathrm{gBpB}$ & <Lim.Mín & - \\
\hline 646 & M & São Vicente & CRF_28/29 & 5.900 & - \\
\hline 647 & M & São Vicente & CRF_28/29 & 12.284 & + \\
\hline 649 & M & São Vicente & $\mathrm{pBeB}$ & 74 & - \\
\hline 658 & $\mathrm{~F}$ & São Vicente & CRF_28/29 & 27.908 & - \\
\hline 661 & M & São Vicente & CRF_28/29 & 49 & - \\
\hline 663 & $\mathrm{~F}$ & São Vicente & CRF_28/29 & 5.042 & - \\
\hline 671 & $\mathrm{~F}$ & São Vicente & CRF_28/29 & 6.900 & - \\
\hline 679 & M & São Vicente & $\mathrm{gBeB}$ & 5.665 & + \\
\hline 691 & $\mathrm{~F}$ & São Vicente & CRF_28/29 & 478 & - \\
\hline 694 & M & São Vicente & CRF_28/29 & 319 & - \\
\hline 704 & $\mathrm{~F}$ & São Vicente & CRF_28/29 & 35.695 & - \\
\hline 712 & $\mathrm{~F}$ & São Vicente & CRF_28/29 & 2.798 & - \\
\hline 722 & $\mathrm{~F}$ & São Vicente & $\mathrm{gBeB}$ & 8.900 & - \\
\hline 731 & $\mathrm{~F}$ & São Vicente & $\mathrm{pB}$ & 8175 & - \\
\hline 734 & M & São Vicente & CRF_28/29 & 49 & - \\
\hline 736 & M & São Vicente & $\mathrm{pBx}$ & 890 & + \\
\hline 744 & $\mathrm{~F}$ & São Vicente & eB & 22.395 & + \\
\hline 746 & $\mathrm{~F}$ & São Vicente & CRF_28/29 & 49 & - \\
\hline
\end{tabular}

${ }^{1}$ HT: heterosexual; HSM: Homens que fazem sexo com homens;UDI: Usuário de droga injetável 2 cópias por ml, ultimo exame disponível.

${ }^{3}$ Ano do primeiro resultado positivo para HIV 
A)

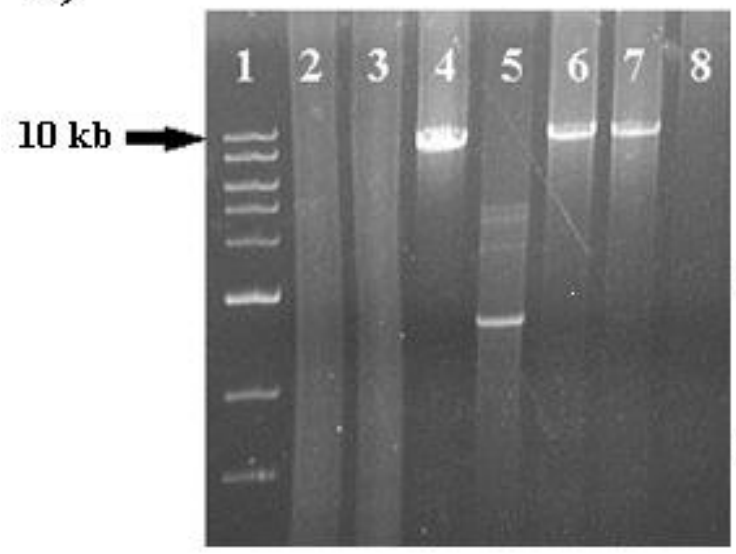

B)

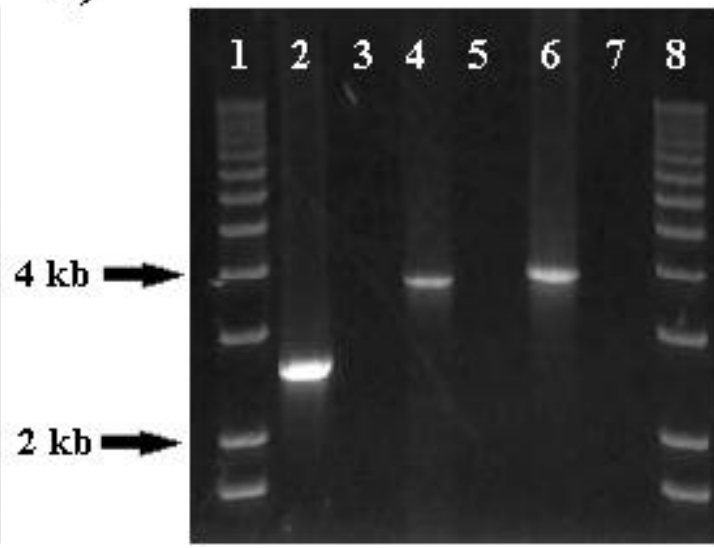

Figura 28- Diferentes estratégias para amplificação do genoma de HIV-1. A) Amplificação do fragmento longo ( $\sim 9 \mathrm{~kb})$ do genoma proviral para os as amostras 0264RI e 0647SV. Na coluna 1 está o marcador de massa molecular $1 \mathrm{~kb}$ (NEB). Nas colunas 2, 3 e 4 estão as diluições (1:5) do DNA da amostra 0264RI, onde é possível observar a amplificação específica apenas na diluição 1:125. Nas colunas 5, 6 e 7 as diluições para a amostra 0647SV, onde é possível observar amplificação de um fragmento bem menor do que o esperado (coluna 5), e amplificação do fragmento esperado nas colunas 6 e 7 (diluições 1:25 e 1:125, respectivamente). Na coluna 8 o controle de reação sem DNA. B) NestedPCR para amplificação dos três fragmentos descritos na Figura 14. Nas linhas 1 e 8 marcador de massa molecular $1 \mathrm{~kb}$ (Invitrogen). Nas linhas 2, 4 e 6 estão os produtos de amplificação esperados. Todos os fragmentos amplificados apresentaram o tamanho esperado, respectivamente, $2,5 \mathrm{~kb}, 3,7 \mathrm{~kb}$ e 3,8 kb. Nas linhas 3, 5 e 7 controle de reação sem DNA.

Apesar da primeira estratégia de amplificação ser a ideal, visto que diminui os riscos de geração de recombinantes artificiais formados pela amplificação de diferentes provírus, ela foi menos eficiente que a segunda estratégia. Portanto, a maioria das amostras sequenciadas foi amplificada em três fragmentos. Após a amplificação e sequenciamento dos fragmentos, o genoma viral foi montado e integridade de cada uma das ORFs foi analisada.

$\mathrm{Na}$ figura 29 é apresentado os resultados da análise de subtipo e do perfil de recombinação, avaliados com o programa jpHMM (ZHANG et al., 2010). Com base no padrão de recombinação ao longo do genoma três isolados foram classificadas como CRF28_BF, três como CRF29_B e quatro como formas recombinantes únicas BF. Entretanto, alguns pontos de recombinação preditos para as amostras identificadas como CRFs foram diferentes dos pontos originalmente descritos para a CRF28 (B: 832 - 1322, F1: 1323 - 2571, B: 2572 - 9432) e CRF29 (B: 823 - 1322, F1: 1323 - 2571, B: 2572 3682, F1: 3683 - 5462, B: 5463 - 9432) (DE SA FILHO et al., 2006). 


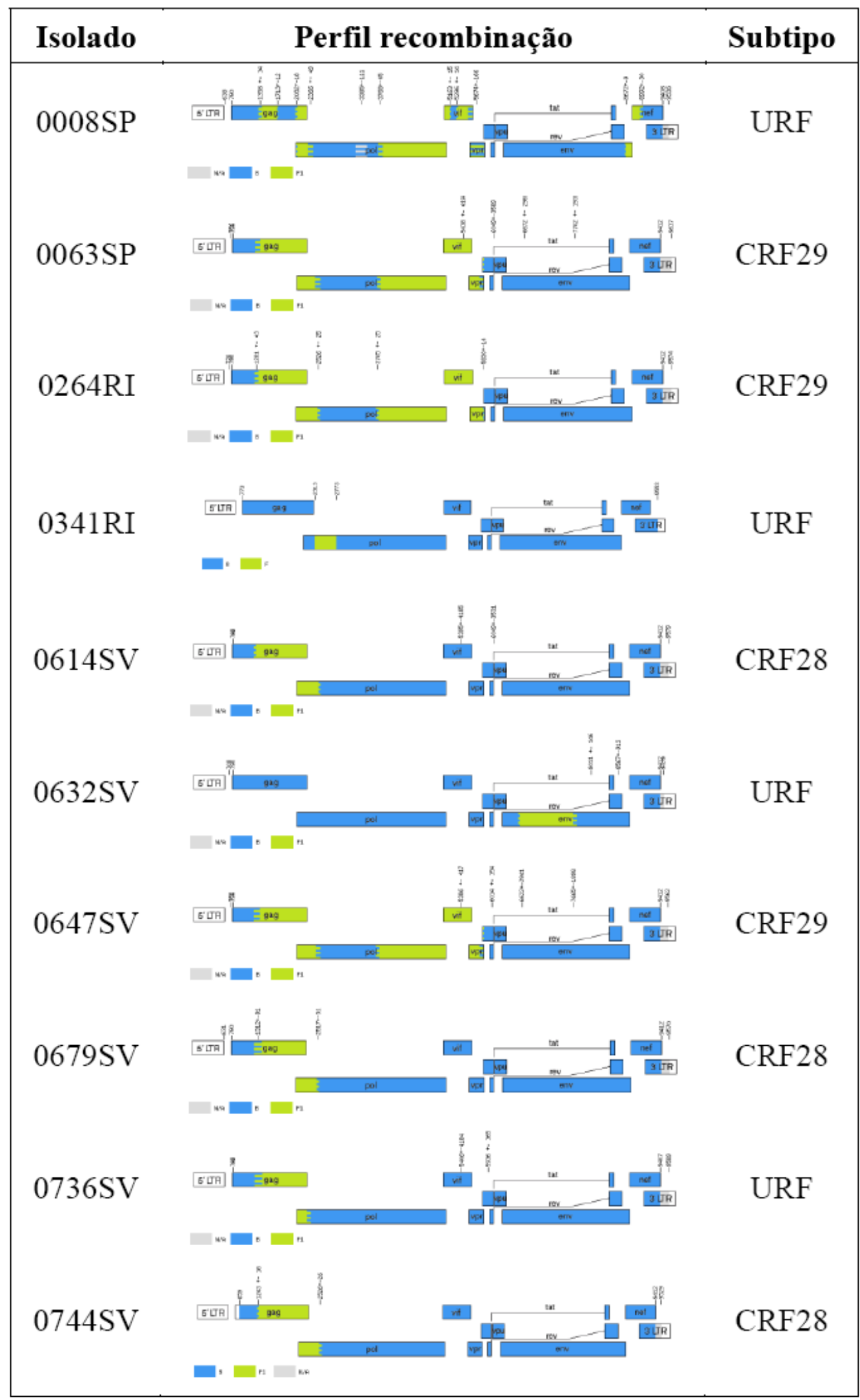

Figura 29- Resumo do perfil de perfil de recombinação determinado pelo programa jpHMM para as amostras isoladas por co-cultivo. Regiões relacionadas ao subtipo B estão representadas em azul e ao subtipo $F$ em verde. 
Para confirmar estes resultados, as amostras de referência das CRF28 e CRF29 foram analisadas da mesma maneira, e de fato os pontos de recombinação preditos pelo programa jpHMM foram diferentes dos descritos originalmente (Figura 30). Apesar de ser eficiente na determinação de eventos de recombinação em HIV, o método de bootscanning utilizado na descrição original destas CRFs é reconhecidamente menos preciso na determinação de pontos de recombinação (SCHULTZ et al., 2006; SCHULTZ et al., 2009). Esta discrepância entre os pontos de recombinação originalmente descritos para as CRF28 e CRF29 e os preditos pelo jpHMM para as já havia sido observada por Zhang et al. (2010), e exemplificam o impacto do método de análise na classificação e identificação de recombinantes em HIV.
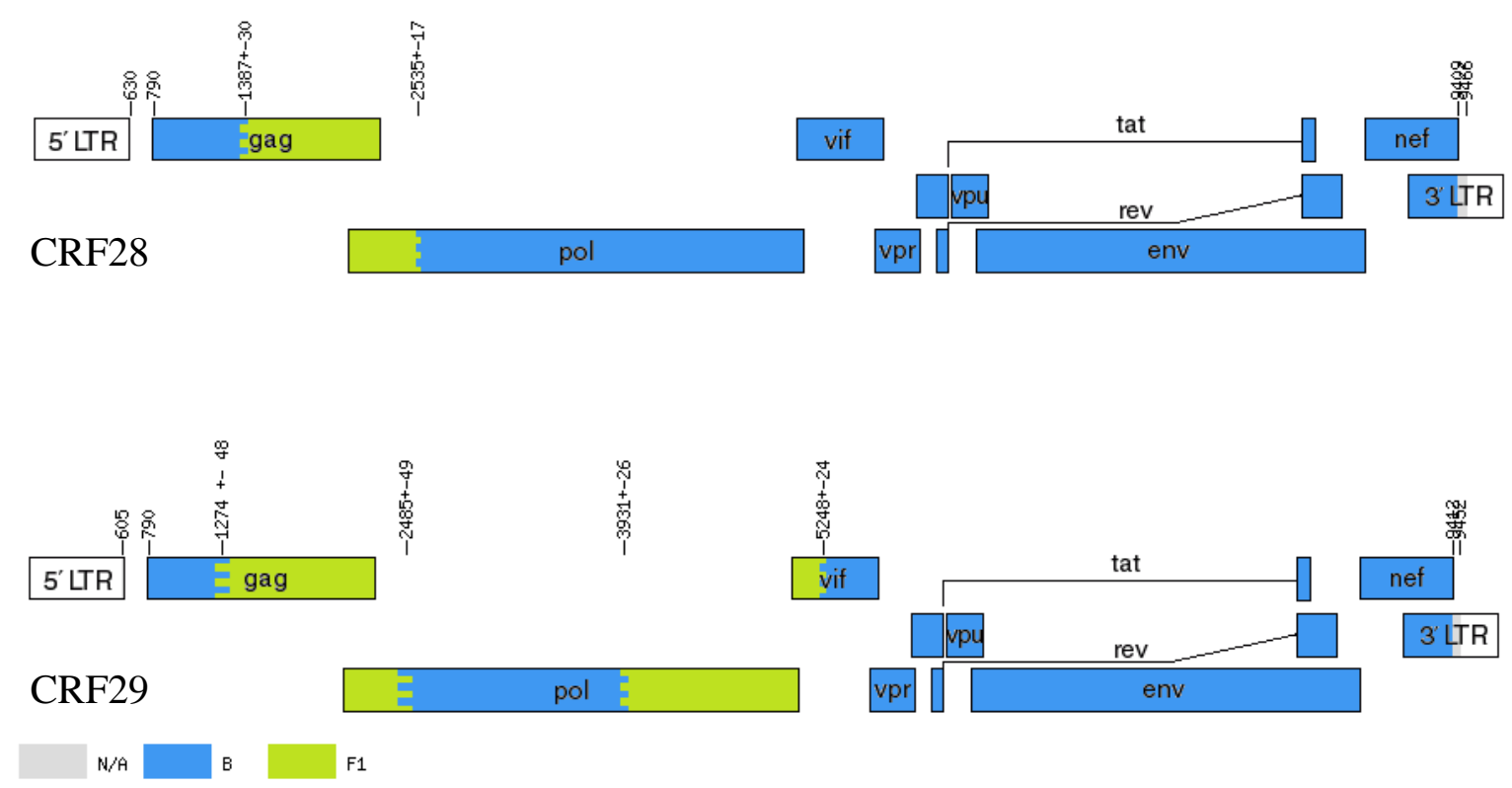

Figura 30- Perfil de recombinação das CRF28 e 29 estimado pelo programa jpHMM.. Alguns pontos de recombinação diferem daqueles descritos originalmente, CRF28 (B: $832-$ 1322, F1: 1323 - 2571, B: 2572 - 9432) e CRF29 (B: 823 - 1322, F1: 1323-2571, B: 2572 - 3682, F1: 3683 - 5462, B: 5463 - 9432). Coordenadas em relação ao HXB2.

Na tabela 11 é possível observar que a data do primeiro exame positivo para HIV do paciente 0063SP portador da CRF29, foi em 1985. Este resultado sugere que a esta CRF tem circulado por ao menos 14 anos antes dos primeiros casos detectados (1999 e 2002)(DE SA FILHO et al., 2006). Alternativamente, este paciente poderia ter sido infectado com um outro subtipo viral e posteriormente ter sido infectado pela CRF29. Entretanto, experimentos realizados em nosso laboratório utilizando de amplificação clonal por diluição limitante e posterior sequenciamento, não revelou nenhuma evidência de co-infecção. Além disso, a data de 1985 concorda com os dados obtidos por Leal et al. (2008a), que estimou a data de origem 
dos recombinantes BF brasileiros para 1984-1991. Portanto, estes resultados indicam que esta CRF surgiu em algum momento antes de 1985.

Em relação aos isolados classificados como formas recombinantes únicas, é interessante destacar o isolado 0736SV, que apresentou um perfil de recombinação

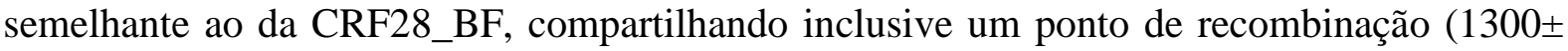
78) (Figura 31). Entretanto o segundo ponto de recombinação identificado $(2317 \pm 34)$ não correspondeu ao ponto descrito para a CRF28 (Figura 30). O mesmo foi observado para o isolado 0008SP, que apesar de apresentar alguns pontos de recombinação semelhantes aos das CRF28 e 29, também apresentou pontos distintos em outras regiões do genoma (Figura 32). Estes resultados sugerem que as CRFs 28 e 29, podem estar envolvidas em novos eventos de recombinação, dando origem a uma segunda geração de sequências recombinantes, como as URFs descritas acima. Alternativamente, este compartilhamento de pontos de recombinação pode ser explicado por uma maior probabilidade de recombinação em algumas regiões do genoma, como por exemplo, pol (GALLI et al., 2008) ou env (SIMON-LORIERE et al., 2010). Entretanto, independente de suas origens, a existência das diferentes URFs descritas neste trabalho (Figuras 20-23, 26 31-30) corrobora resultados prévios mostrando que eventos de superinfecção são frequentes (PIANTADOSI et al., 2007). Esta alta frequência de superinfecção e a co-circulação de múltiplos subtipos favorecem o aparecimento de URFs que futuramente podem emergir como CRFs, assim como as seis formas circulantes já descritas no Brasil (DE SA FILHO et al., 2006; SANTOS et al., 2006; GUIMARAES et al., 2008; SANABANI et al., 2010).

Curiosamente, o isolado 0632SV classificado aqui como uma URF, pode na verdade representar uma nova CRF presente no Estado de São Paulo dado que apresenta o mesmo perfil de recombinação que a amostra 02BR005 (DQ358806) descrita por Sanabani et al. (2006) no município de São Paulo (Figura 33). Os critérios para a descrição de uma CRF não foram completamente preenchidos visto que apenas dois casos foram encontrados. 
TABELA 11- Dados clínicos dos pacientes cujo isolamento viral foi positivo.

\begin{tabular}{|c|c|c|c|c|c|c|c|}
\hline Paciente & Sexo & Risco $^{1}$ & Ano Diagnóstico & AIDS & CD4 $(\mathrm{cel} / \mathrm{ml})^{3}$ & 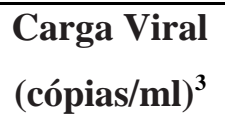 & $\begin{array}{c}\text { Tratamento } \\
\text { antirretroviral }\end{array}$ \\
\hline 0008SP & Feminino & HT & 1996 & - & 595 & 450 & NRTI+NRTI \\
\hline 0063SP & Masculino & HT, UDI, TS & 1985 & + & 10 & 45,600 & NRTI+NRTI+PI \\
\hline 0264RI & Masculino & HSH, UDI & 1995 & + & 632 & 22,000 & Nenhum \\
\hline 0341RI & Feminino & HT/TS & 1995 & - & 554 & 54,500 & NRTI+NRTI \\
\hline $0614 \mathrm{SV}$ & Masculino & $\mathrm{HT}$ & 1998 & + & 499 & $<50$ & NRTI+NRTI+PI \\
\hline 0632SV & Masculino & $\mathrm{HT}$ & 2003 & - & 169 & 150,347 & NRTI+NRTI+PI \\
\hline $0647 \mathrm{SV}$ & Masculino & $\mathrm{HT}$ & 1995 & - & NA & 12,284 & Nenhum \\
\hline 0679SV & Masculino & $\mathrm{HT}$ & 1995 & + & 202 & 5,665 & NRTI+NRTI+PI \\
\hline 0736SV & Masculino & HSH, UDI & 1992 & - & 693 & 890 & NRTI+NRTI \\
\hline
\end{tabular}

${ }^{1}$ HT: Heterosexual; HSM: Homens que fazem sexo com homens;UDI: Usuário de droga injetável, TS: Transfusão de sangue;

2 Ano do primeiro resultado positivo para HIV;

${ }^{3}$ Último exame disponível;

${ }^{4}$ Não disponível. 

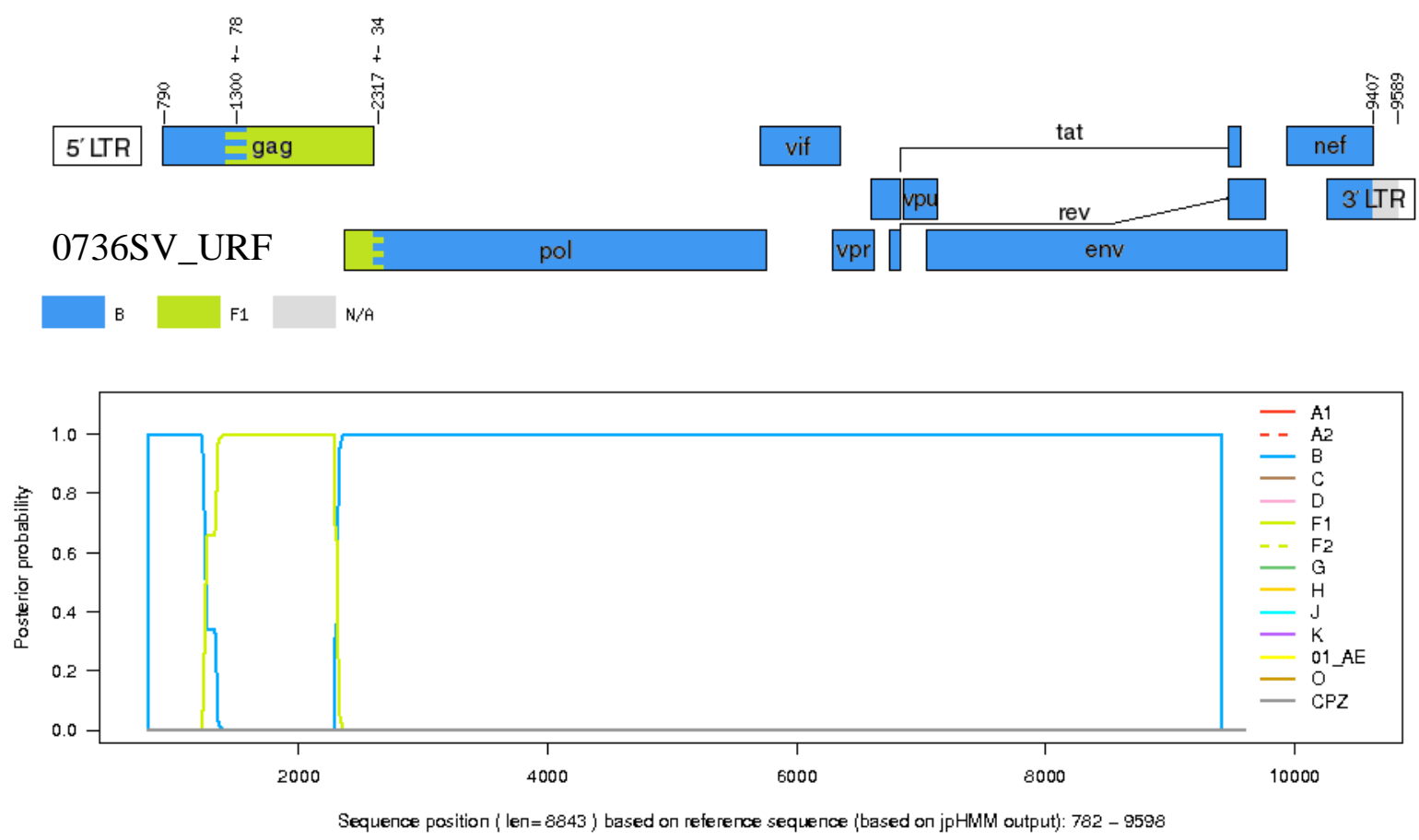

Figura 31- Perfil de recombinação do isolado 0736SV_URF e valores de probabilidade posterior. O ponto de recombinação na posição $1300 \pm 78$ está presente nas CRF28 e 29 . Entretanto o segundo ponto de recombinação na posição $2317 \pm 34$ é diferente do encontrado na CRF28. Coordenadas em relação ao HXB2.
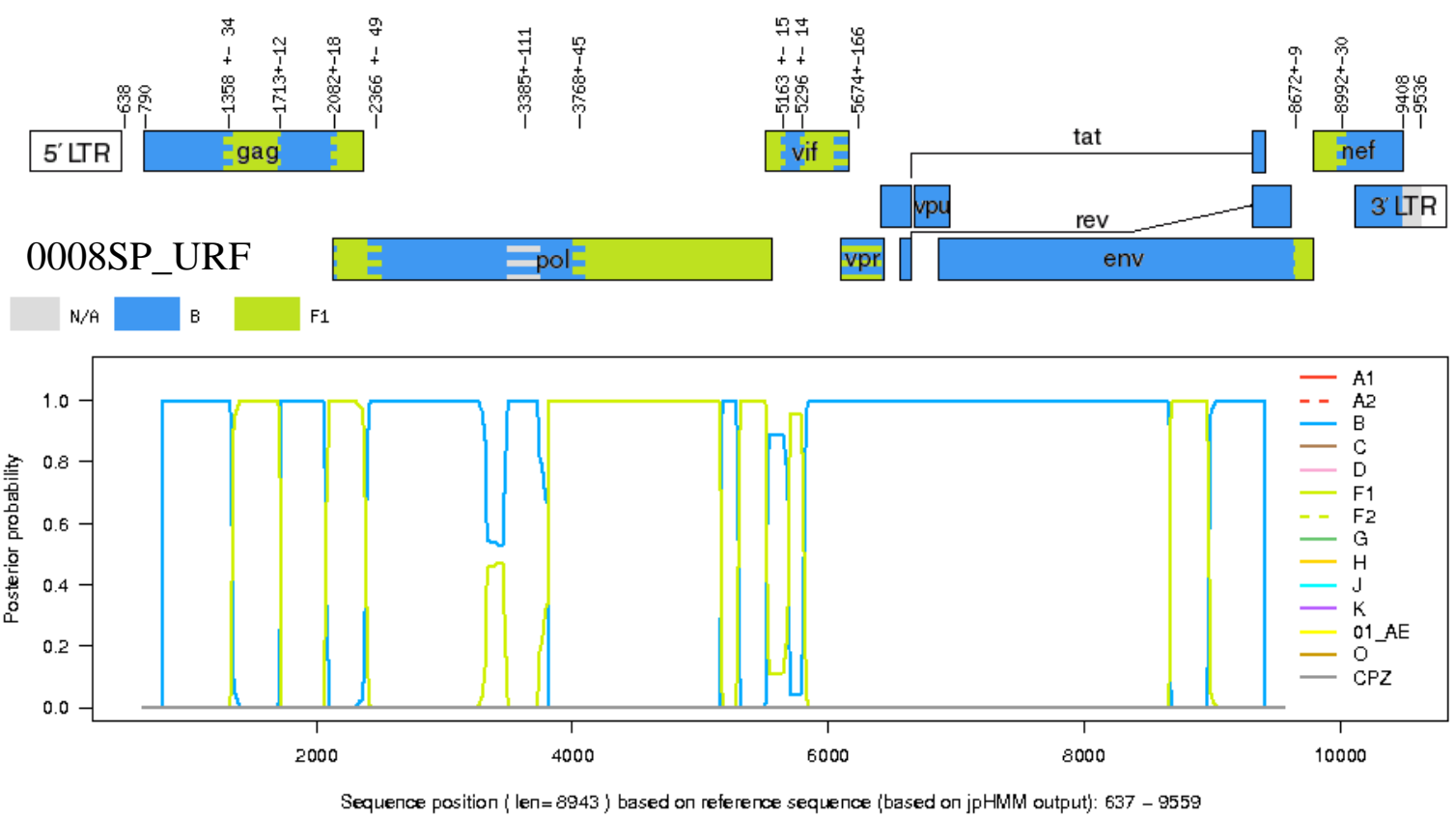

Figura 32- Perfil de recombinação do isolado 0008SP e valores de probabilidade posterior. Apesar de compartilhar pontos de quebras com as CRF28 e 29, este isolado apresenta um padrão mais complexo de recombinação. Coordenadas em relação ao HXB2. 


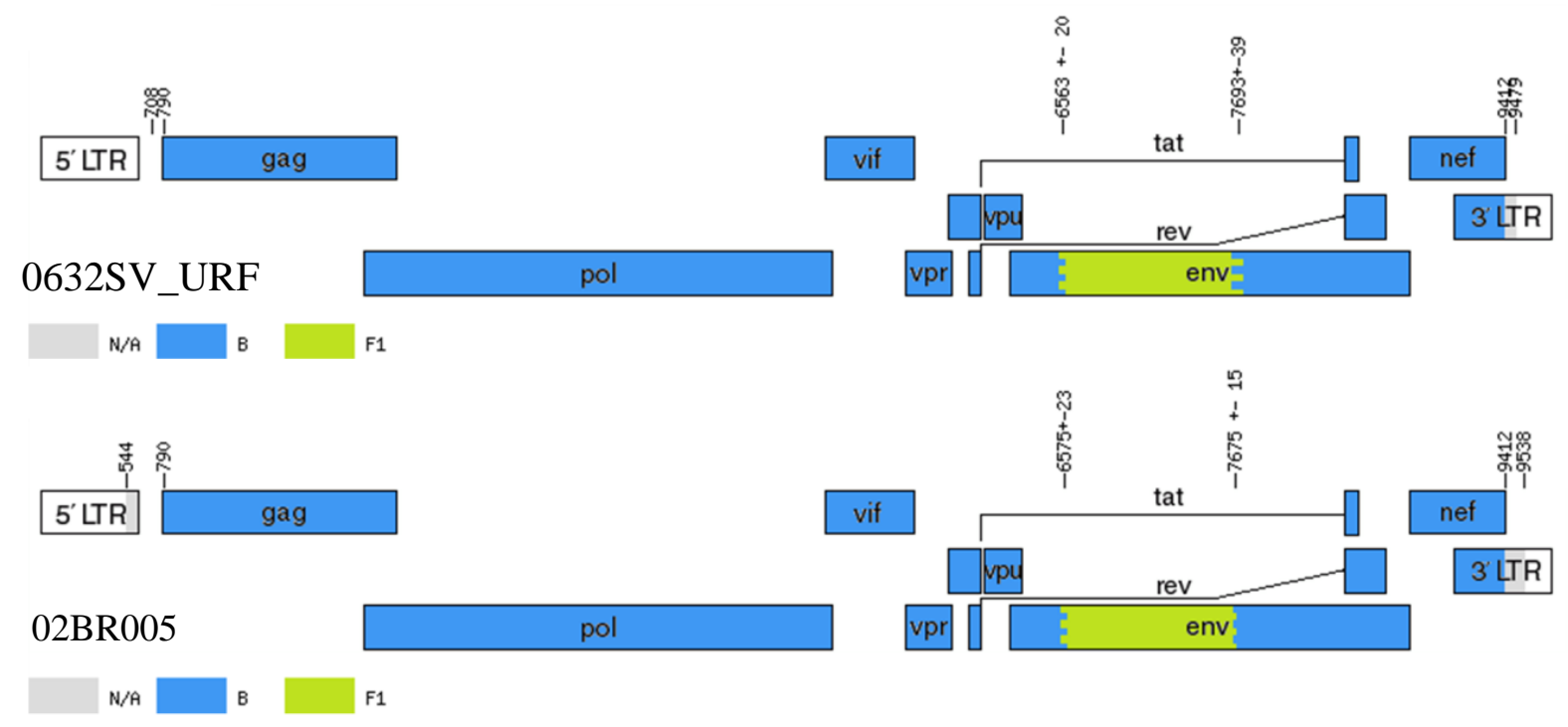

Figura 33- Perfil de recombinação para o isolado 0632SV e para a amostra 02BR005 (DQ358806) descrita por Sanabani et al. (2006).

A caracterização do uso de correceptores foi realizada por métodos fenotípicos e genotípicos. Os resultados obtidos pelas duas abordagens estão descritos na Tabela 12. O método fenotípico empregado é baseado na detecção da expressão de $g f p$ após infecção pelo HIV-1, exemplificado na figura 34. De acordo com os resultados do ensaio fenotípico, os isolados 0314RI, 0614SV e 647SV foram capazes de utilizar os dois correceptores (duplotrópicos ou R5/X4), ou seja, induziram fluorescência nas linhagens transformadas com CCR5 e nas linhagens transformadas com CXCR4. Os isolados os isolados 0632SV, 0679SV e 0744SV foram capazes de utilizar apenas CCR5 (R5), enquanto que os demais utilizaram apenas CXCR4 (X4).

Como descrito anteriormente, o uso de CCR5 nas linhagens GHOST(3) deve ser confirmado com a adição de um antagonista de CXCR4 (AMD3100). Na presença desse antagonista apenas os isolados R5/X4 e os R5 foram capazes de se replicar nas células GHOST(3)-CCR5, confirmando portanto o uso de CCR5. Nenhum dos isolados foi capaz de infectar as células GHOST(3)-CXCR4 na presença do antagonista. Apesar do número limitado de isolados, nenhuma relação foi encontrada entre o uso de coreceptores e os dados clínicos apresentados na tabela 11. 


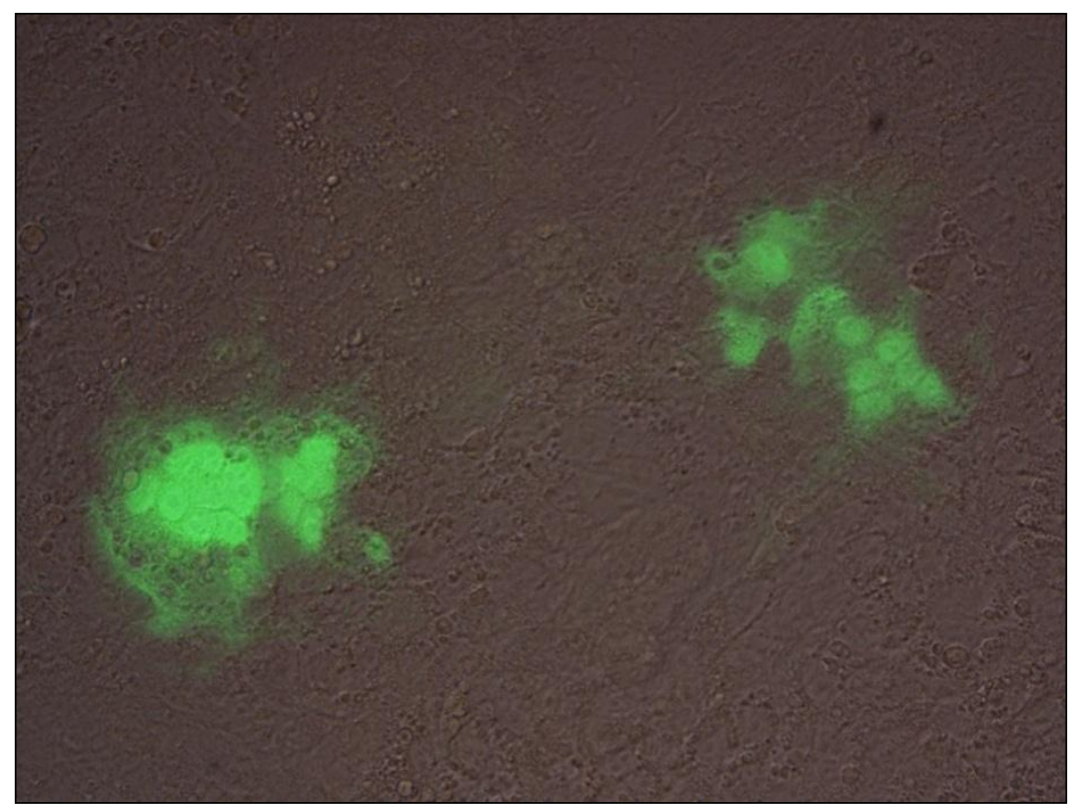

Figura 34- Exemplo de sincício encontrado nas células GHOST(3) após infecção com os isolados primários (aumento de 20x). Neste campo é possível observar dois sincícios, e ao redor destes sincícios as células não apresentam fluorescência, indicando ausência de infecção.

Adicionalmente, a análise dos aminoácidos da coroa V3 revelou uma grande variedade de formas (Tabela 12), e nenhuma relação entre o uso entre o motivo da coroa e o uso de correceptores foi observado, sendo que o motivo GWGR foi encontrado tanto em isolados R5 quanto X4, corroborando os resultados encontrados por Ferraro et al. (2001). Em conjunto, estes resultados fornecem evidência empírica do uso de CXCR4 por variantes GWGR, ao contrário do sugerido por Leal et al. (2008) de que variantes GWGR utilizam exclusivamente CCR5. Além disso, estes resultados também forneceram evidência de que o motivo presente na coroa V3 não deve ser considerado isoladamente como um fator determinante no uso de correceptores, como sugerido por Tomasini-Grotto et al. (2010). Em relação aos métodos de predição do uso de correceptores, o algoritmo geno2pheno foi capaz de identificar corretamente todos os isolados capazes de utilizar CXCR4 (7/7), enquanto que o algoritmo WebPSSM identificou apenas 4/7. Está comparação entre diferentes algoritmos é interessante visto que os inibidores de CCR5 já estão sendo utilizados no Brasil e é importante que a presença de variantes capazes de utilizar CXCR4 seja identificada antes da prescrição destes inibidores.

Em suma, a obtenção de isolados primários das CRF28 e CRF29 e a caracterização in vitro do uso de correceptores representam o primeiro passo no estudo das formas recombinantes $\mathrm{BF}$ presentes na epidemia brasileira. 
TABELA 12- Caracterização do uso de correceptores para os diferentes isolados.

\begin{tabular}{|c|c|c|c|c|c|c|c|}
\hline Amostra & Subtipo & Env & Coroa V3 & Geno2pheno & WebPSSM & Fenotipagem & AMD \\
\hline 0008SP & URF & B & GPGR & $\mathrm{X} 4$ & R5 & $\mathrm{X} 4$ & $\operatorname{sim}$ \\
\hline 0063SP & CRF29 & B & GSGR & $\mathrm{X} 4$ & $\mathrm{X} 4$ & $\mathrm{X} 4$ & $\operatorname{sim}$ \\
\hline 0264RI & CRF29 & B & GRGR & $\mathrm{X} 4$ & $\mathrm{X} 4$ & $\mathrm{X} 4$ & $\operatorname{sim}$ \\
\hline 0341RI & URF & B & GLGR & $\mathrm{X} 4$ & R5 & $\mathrm{R} 5 / \mathrm{X} 4$ & não \\
\hline 0614SV & CRF28 & B & GPGR & $\mathrm{X} 4$ & $\mathrm{X} 4$ & R5/X4 & não \\
\hline 0632SV & URF & $\mathrm{F}$ & GPGK & R5 & R5 & R5 & não \\
\hline 0647SV & CRF29 & B & GWGR & $\mathrm{X} 4$ & $\mathrm{X} 4$ & $\mathrm{R} 5 / \mathrm{X} 4$ & não \\
\hline 0679SV & CRF28 & B & GWGR & R5 & R5 & R5 & não \\
\hline 0736SV & URF & B & GVGR & $\mathrm{X} 4$ & R5 & $\mathrm{X} 4$ & $\operatorname{sim}$ \\
\hline 0744SV & CRF28 & B & GWGR & R5 & R5 & R5 & não \\
\hline
\end{tabular}

${ }^{1}$ capazes de infectar GHOST-CCR5 na presença do inibidor AMD. 


\section{CONCLUSÕES}

- Ao todo foram analisadas 1083 pacientes do projeto VGDN, e 152 foram caracterizados como portadores de recombinantes BF.

- Os municípios de São Vicente e Sorocaba foram os que apresentaram uma maior quantidade de formas recombinantes.

- Em São Vicente a maioria das amostras apresentou um perfil compatível com as CRFs 28 e CRF29, e em Sorocaba a maioria das amostras recombinantes apresentou o env do subtipo F, independente do perfil no restante dos genes.

- Foram sequenciadas 159 integrases e 11 apresentaram evidência de recombinação intragênica. Não foram encontradas mutações primárias de resistência.

- Foram isoladas 10 formas recombinantes BF, e após o sequenciamento do genoma estes isolados foram classificados como três CRF28_BF, três CRF29_BF e quatro formas recombinantes únicas.

- Destes isolados três foram capazes de utilizar tanto CCR5 quanto CXCR4, quatro utilizaram somente CXCR4 e três utilizaram somente CCR5. Nenhuma relação entre os subtipos, características clinicas do paciente e uso de correceptores foi encontrada. 


\section{REFERÊNCIAS*}

ABECASIS, A. B. et al. Recombination confounds the early evolutionary history of human immunodeficiency virus type 1 : subtype $\mathrm{G}$ is a circulating recombinant form. J. Virol., v. 81, n. 16, p. 8543-8551, 2007.

AIKEN, C. et al. Nef induces CD4 endocytosis: requirement for a critical dileucine motif in the membrane-proximal CD4 cytoplasmic domain. Cell, v. 76, n. 5, p. 853-864, 1994.

ANDRAKE, M. D.; SKALKA, A. M. Retroviral integrase, putting the pieces together. J. Biol. Chem., v. 271, n. 33, p. 19633-19636, 1996.

ARHEL, N. Revisiting HIV-1 uncoating. Retrovirology, v. 7, p. 96, 2010.

ARNAUD, F. et al. Interplay between Ovine Bone Marrow Stromal Cell Antigen 2/Tetherin and Endogenous Retroviruses. J. Virol., v. 84, n. 9, p. 4415-4425, 2010.

ARORA, P.; DIXIT, N. M. Timing the emergence of resistance to anti-HIV drugs with large genetic barriers. PLoS Comput. Biol., v. 5, n. 3, p. e1000305, 2009.

ARRUDA, L. B. et al. Genetic Diversity on the Integrase Region of the pol Gene among HIV Type 1-Infected Patients Naive for Integrase Inhibitors in Sao Paulo City, Brazil. AIDS Res. Hum. Retroviruses, v. 26, n. 1, p. 105-107, 2010.

AULICINO, P. C. et al. Extremely rapid spread of human immunodeficiency virus type $1 \mathrm{BF}$ recombinants in Argentina. J. Virol., v. 81, n. 1, p. 427-9, 2007.

AWADALLA, P. The evolutionary genomics of pathogen recombination. Nat. Rev. Genet., v. 4, n. 1, p. 50-60, 2003.

BACHAND, F. et al. Incorporation of $\mathrm{Vpr}$ into human immunodeficiency virus type 1 requires a direct interaction with the p6 domain of the p55 Gag precursor. J. Biol. Chem., v. 274, n. 13, p. 9083-9091, 1999.

BARRE-SINOUSSI, F. et al. Isolation of a T-lymphotropic retrovirus from a patient at risk for acquired immune deficiency syndrome (AIDS). Science, v. 220, n. 4599, p. 868-871, 1983.

*De acordo com:

ASSOCIAÇÃO BRASILEIRA DE NORMAS TÉCNICAS. NBR 6023: Informação e documentação: referências: elaboração. Rio de Janeiro, 2002 
BERGER, E. A.; MURPHY, P. M.; FARBER, J. M. Chemokine receptors as HIV-1 coreceptors: roles in viral entry, tropism, and disease. Annu. Rev. Immunol., v. 17, p. 657$700,1999$.

BERKHOUT, B.; SILVERMAN, R. H.; JEANG, K. T. Tat Trans-Activates the Human Immunodeficiency Virus through a Nascent Rna Target. Cell, v. 59, n. 2, p. 273-282, 1989.

BONGERTZ, V. et al. HIV-1 diversity in Brazil: genetic, biologic, and immunologic characterization of HIV-1 strains in three potential HIV vaccine evaluation sites. Brazilian Network for HIV Isolation and Characterization. J. Acquir. Immune Defic. Syndr., v. 23, n. 2, p. 184-193, 2000.

BONI, M. F.; POSADA, D.; FELDMAN, M. W. An exact nonparametric method for inferring mosaic structure in sequence triplets. Genetics, v. 176, n. 2, p. 1035-1047, 2007.

BRENNAN, C. A. et al. HIV-1 strains identified in Brazilian blood donors: Significant prevalence of B/F1 recombinants. AIDS Res. Hum. Retroviruses, v. 23, n. 11, p. 1434-1441, 2007.

BRIGATI, C. et al. HIV Tat, its TARgets and the control of viral gene expression. FEMS Microbiol. Lett., v. 220, n. 1, p. 57-65, 2003.

BRIGIDO, L. F. et al. Southern Brazil HIV Type 1 C Expansion into the State of Sao Paulo, Brazil. AIDS Res. Hum. Retroviruses, v. 26. doi: 10.1089/aid.2010.0157.

BRINDEIRO, R. et al. Sequence diversity of the reverse transcriptase of human immunodeficiency virus type 1 from untreated Brazilian individuals. Antimicrob. Agents Chemother., v. 43, n. 7, p. 1674-1680, 1999.

BRINDEIRO, R. M. et al. Brazilian Network for HIV Drug Resistance Surveillance (HIVBResNet): a survey of chronically infected individuals. AIDS, v. 17, n. 7, p. 1063-1069, 2003.

BRIONES, M. S.; DOBARD, C. W.; CHOW, S. A. Role of Human Immunodeficiency Virus Type 1 Integrase in Uncoating of the Viral Core. J. Virol., v. 84, n. 10, p. 5181-5190, 2010.

BRYANT, M.; RATNER, L. Myristoylation-dependent replication and assembly of human immunodeficiency virus 1. Proc. Natl. Acad. Sci. U. S. A., v. 87, n. 2, p. 523-527, 1990. 
BUKRINSKY, M. I. et al. Association of integrase, matrix, and reverse transcriptase antigens of human immunodeficiency virus type 1 with viral nucleic acids following acute infection. Proc. Natl. Acad. Sci. U. S. A., v. 90, n. 13, p. 6125-6129, 1993.

CABRAL, V. P. et al. Human immunodeficiency virus type-1 subtypes of infected patients in Espirito Santo, Brazil. Mem. Inst. Oswaldo Cruz, v. 101, n. 8, p. 881-885, 2006.

CAI, M. et al. Solution structure of the N-terminal zinc binding domain of HIV-1 integrase. Nat. Struct. Biol., v. 4, n. 7, p. 567-577, 1997.

CARIDE, E. Drug-Resistant Reverse Transcriptase Genotyping and Phenotyping of B and Non-B Subtypes (F and A) of Human Immunodeficiency Virus Type I Found in Brazilian Patients Failing HAART. Virology, v. 275, n. 1, p. 107-115, 2000.

CARR, J. K. et al. Diverse BF recombinants have spread widely since the introduction of HIV-1 into South America. AIDS, v. 15, n. 15, p. 41-47, 2001.

CARR, J. K. et al. Characterization of subtype A HIV-1 from Africa by full genome sequencing. AIDS, v. 13, n. 14, p. 1819-1826, 1999.

CARR, J. K. et al. Full genome sequences of human immunodeficiency virus type 1 subtypes G and A/G intersubtype recombinants. Virology, v. 247, n. 1, p. 22-31, 1998.

CARR, J. K. et al. Full-length sequence and mosaic structure of a human immunodeficiency virus type 1 isolate from Thailand. J. Virol., v. 70, n. 9, p. 5935-5943, 1996.

CHARPENTIER, C. et al. Extensive recombination among human immunodeficiency virus type 1 quasispecies makes an important contribution to viral diversity in individual patients. J. Virol., v. 80, n. 5, p. 2472-2482, 2006.

CIUFFI, A. et al. A role for LEDGF/p75 in targeting HIV DNA integration. Nat. Med., v. 11, n. 12, p. 1287-1289, 2005.

CLAVEL, F. et al. Isolation of a new human retrovirus from West African patients with AIDS. Science, v. 233, n. 4761, p. 343-346, 1986.

COCHRANE, A. et al. The Human Immunodeficiency Virus Rev Protein Is a Nuclear Phosphoprotein. Virology, v. 171, n. 1, p. 264-266, 1989. 
COFFIN, J. M.; HUGHES, S. H.; VARMUS, H. E. Retroviruses. New York: Cold Spring Harbor Laboratory Press, 1997.

COHEN, E. A. et al. Human immunodeficiency virus vpr product is a virion-associated regulatory protein. J. Virol., v. 64, n. 6, p. 3097-3099, 1990.

DAECKE, J. et al. Involvement of clathrin-mediated endocytosis in human immunodeficiency virus type 1 entry. J. Virol., v. 79, n. 3, p. 1581-1594, 2005.

DAMOND, F. et al. Identification of a highly divergent HIV type 2 and proposal for a change in HIV type 2 classification. AIDS Res. Hum. Retroviruses, v. 20, n. 6, p. 666-672, 2004.

DE OLIVEIRA, T. et al. An automated genotyping system for analysis of HIV-1 and other microbial sequences. Bioinformatics, v. 21, n. 19, p. 3797-3800, 2005.

DE SA FILHO, D. J. et al. Identification of two HIV type 1 circulating recombinant forms in Brazil. AIDS Res. Hum. Retroviruses, v. 22, n. 1, p. 1-13, 2006.

DE SOUZA, A. C. et al. Short communication: Molecular characterization of HIV type 1 BF pol recombinants from Sao Paulo, Brazil. AIDS Res. Hum. Retroviruses, v. 24, n. 12, p. 1521-1525, 2008.

DELGADO, E. et al. Identification of a new HIV type 1 BF intersubtype circulating recombinant form (CRF44_BF) in Chile. AIDS Res. Hum. Retroviruses, v. 26, n. 7, p. 821$826,2010$.

DEMARCHI, F. et al. Activation of transcription factor NF-kappa B by the tat protein of human immunodeficiency virus type 1. J. Virol., v. 70, n. 7, p. 4427-4437, 1996.

DOMS, R. W. Unwelcome guests with master keys: how HIV enters cells and how it can be stopped. Top HIV Med, v. 12, n. 4, p. 100-103, 2004.

DOMS, R. W.; PEIPER, S. C. Unwelcomed guests with master keys: how HIV uses chemokine receptors for cellular entry. Virology, v. 235, n. 2, p. 179-190, 1997.

DORFMAN, T. et al. Role of the matrix protein in the virion association of the human immunodeficiency virus type 1 envelope glycoprotein. J. Virol., v. 68, n. 3, p. 1689-1696, 1994. 
DUBE, M. et al. Antagonism of tetherin restriction of HIV-1 release by Vpu involves binding and sequestration of the restriction factor in a perinuclear compartment. PLoS Pathog., v. 6, n. 4, p. e1000856, 2010.

DUSSUPT, V. et al. The nucleocapsid region of HIV-1 Gag cooperates with the PTAP and LYPXnL late domains to recruit the cellular machinery necessary for viral budding. PLoS Pathog., v. 5, n. 3, p. e1000339, 2009.

DYDA, F. et al. Crystal structure of the catalytic domain of HIV-1 integrase: similarity to other polynucleotidyl transferases. Science, v. 266, n. 5193, p. 1981-1986, 1994.

EDGAR, R. C. MUSCLE: multiple sequence alignment with high accuracy and high throughput. Nucleic Acids Res., v. 32, n. 5, p. 1792-1797, 2004.

EDMONSON, P. F.; MULLINS, J. I. Efficient Amplification of Hiv Half-Genomes from Tissue DNA. Nucleic Acids Res., v. 20, n. 18, p. 4933-4933, 1992.

ETHERINGTON, G. J.; DICKS, J.; ROBERTS, I. N. Recombination Analysis Tool (RAT): a program for the high-throughput detection of recombination. Bioinformatics, v. 21, n. 3, p. 278-281, 2005.

FANG, G. et al. Recombination following superinfection by HIV-1. AIDS, v. 18, n. 2, p. 153 $159,2004$.

FARNET, C. M.; BUSHMAN, F. D. HIV-1 cDNA integration: requirement of HMG I(Y) protein for function of preintegration complexes in vitro. Cell, v. 88, n. 4, p. 483-492, 1997.

FARNET, C. M.; HASELTINE, W. A. Determination of viral proteins present in the human immunodeficiency virus type 1 preintegration complex. J. Virol., v. 65, n. 4, p. 1910-1915, 1991.

FENG, Y. et al. HIV-1 entry cofactor: functional cDNA cloning of a seven-transmembrane, G protein-coupled receptor. Science, v. 272, n. 5263, p. 872-877, 1996.

FENYO, E. et al. International network for comparison of HIV neutralization assays: the NeutNet report. PLoS ONE, v. 4, n. 2, p. e4505, 2009. 
FERNANDEZ-GARCIA, A. et al. Identification of a new HIV type 1 circulating BF intersubtype recombinant form (CRF47_BF) in Spain. AIDS Res. Hum. Retroviruses, v. 26, n. 7, p. 827-832, 2010.

FERRARO, G. A. et al. Biological characterization and chemokine receptor usage of HIV type 1 isolates prevalent in Brazil. AIDS Res. Hum. Retroviruses, v. 17, n. 13, p. 12411247, 2001.

FITZPATRICK, K. et al. Direct restriction of virus release and incorporation of the interferon-induced protein BST-2 into HIV-1 particles. PLoS Pathog., v. 6, n. 3, p. e1000701, 2010 .

FOSTER, J. L.; GARCIA, J. V. HIV-1 Nef: at the crossroads. Retrovirology, v. 5, n. 1, p. 8497, 2008.

FRANKEL, A. D.; YOUNG, J. A. HIV-1: fifteen proteins and an RNA. Annu. Rev. Biochem., v. 67, p. 1-25, 1998.

FRENKEL, L. M. et al. Specific, Sensitive, and Rapid Assay for Human-ImmunodeficiencyVirus Type-1 Pol Mutations Associated with Resistance to Zidovudine and Didanosine. J. Clin. Microbiol., v. 33, n. 2, p. 342-347, 1995.

GALETTO, R.; NEGRONI, M. Mechanistic features of recombination in HIV. AIDS Rev., v. 7, n. 2, p. 92-102, 2005.

GALLI, A. et al. Recombination analysis and structure prediction show correlation between breakpoint clusters and RNA hairpins in the pol gene of human immunodeficiency virus type 1 unique recombinant forms. J. Gen. Virol., v. 89, p. 3119-3125, 2008.

GALLO, R. et al. Isolation of human T-cell leukemia virus in acquired immune deficiency syndrome (AIDS). Science, v. 220, n. 4599, p. 865-867, 1983.

GAO, F. et al. Origin of HIV-1 in the chimpanzee Pan troglodytes troglodytes. Nature, v. 397, n. 6718, p. 436-441, 1999.

GAO, F. et al. The heterosexual human immunodeficiency virus type 1 epidemic in Thailand is caused by an intersubtype (A/E) recombinant of African origin. J. Virol., v. 70, n. 10, p. 7013-7029, 1996. 
GAO, F. et al. Evidence of two distinct subsubtypes within the HIV-1 subtype A radiation. AIDS Res. Hum. Retroviruses, v. 17, n. 8, p. 675-688, 2001.

GARCIA, J. V.; MILLER, A. D. Serine phosphorylation-independent downregulation of cellsurface CD4 by nef. Nature, v. 350, n. 6318, p. 508-511, 1991.

GIBBS, M. J.; ARMSTRONG, J. S.; GIBBS, A. J. Sister-scanning: a Monte Carlo procedure for assessing signals in recombinant sequences. Bioinformatics, v. 16, n. 7, p. 573-582, 2000.

GOETHALS, O. et al. Primary mutations selected in vitro with raltegravir confer large fold changes in susceptibility to first-generation integrase inhibitors, but minor fold changes to inhibitors with second-generation resistance profiles. Virology, v. 402, n. 2, p. 338-346, 2010.

GOMEZ CARRILLO, M.; PICCARDO, C.; LIBONATTI, O. Molecular analysis of the principal neutralization epitope (V3 loop) of human immunodeficiency virus type 1 in Argentina. Rev. Argent. Microbiol., v. 24, n. 2, p. 91-101, 1992.

GOTTLIEB, M. S. et al. Pneumocystis carinii pneumonia and mucosal candidiasis in previously healthy homosexual men: evidence of a new acquired cellular immunodeficiency. N. Engl. J. Med., v. 305, n. 24, p. 1425-1431, 1981.

GÖTTLINGER, H. G. HIV-1 Gag: a Molecular Machine Driving Viral Particle Assembly and Release. In: KUIKEN, C. et al. (Ed.). HIV Sequence Compendium. Los Alamos, NM: Theoretical Biology and Biophysics Group, Los Alamos National Laboratory, 2001. p. 2-28.

GOTTLINGER, H. G. et al. Effect of mutations affecting the p6 gag protein on human immunodeficiency virus particle release. Proc. Natl. Acad. Sci. U. S. A., v. 88, n. 8, p. 3195 3199, 1991.

GRASSLY, N. C.; HOLMES, E. C. A likelihood method for the detection of selection and recombination using nucleotide sequences. Mol. Biol. Evol., v. 14, n. 3, p. 239-247, 1997.

GROOM, H. C. et al. Susceptibility of xenotropic murine leukemia virus-related virus (XMRV) to retroviral restriction factors. Proc. Natl. Acad. Sci. U. S. A., v. 107, n. 11, p. 5166-5171, 2010.

GUIMARAES, M. et al. Identification of two new CRF_BF in Rio de Janeiro State, Brazil. AIDS, v. 22, n. 3, p. 433-435, 2008. 
GUIMARÃES, M. L. et al. Analysis of HIV-1 BF pr/rt recombinant strains from Rio de Janeiro/Brazil reveals multiple unrelated mosaic structures. Infect. Genet. Evol., v. 10, n. 7 , p. 1094-1100, 2010.

GURTLER, L. et al. A new subtype of human immunodeficiency virus type 1 (MVP-5180) from Cameroon. J. Virol., v. 68, n. 3, p. 1581-1585, 1994.

HARE, S. et al. Retroviral intasome assembly and inhibition of DNA strand transfer. Nature, v. 464, n. 7286, p. 232-236, 2010.

HARRICH, D. et al. Tat is required for efficient HIV-1 reverse transcription. EMBO J., v. 16, n. 6, p. 1224-1235, 1997.

HARRISON, G. P.; LEVER, A. M. The human immunodeficiency virus type 1 packaging signal and major splice donor region have a conserved stable secondary structure. J. Virol., v. 66, n. 7, p. 4144-4153, 1992.

HAZUDA, D. J. et al. A naphthyridine carboxamide provides evidence for discordant resistance between mechanistically identical inhibitors of HIV-1 integrase. Proc. Natl. Acad. Sci. U. S. A., v. 101, n. 31, p. 11233-11238, 2004.

HE, J. et al. Human immunodeficiency virus type 1 viral protein $\mathrm{R}(\mathrm{Vpr})$ arrests cells in the G2 phase of the cell cycle by inhibiting p34cdc2 activity. J. Virol., v. 69, n. 11, p. 6705-6711, 1995.

HEIN, J. A Heuristic Method to Reconstruct the History of Sequences Subject to Recombination. J. Mol. Evol., v. 36, n. 4, p. 396-405, 1993.

HEINZINGER, N. K. et al. The Vpr protein of human immunodeficiency virus type 1 influences nuclear localization of viral nucleic acids in nondividing host cells. Proc. Natl. Acad. Sci. U.S.A., v. 91, n. 15, p. 7311-7315, 1994.

HEYNDRICKX, L. et al. HIV-1 group O and group M dual infection in Benin. Lancet, v. 347, n. 9005, p. 902-903, 1996.

HILL, M.; TACHEDJIAN, G.; MAK, J. The packaging and maturation of the HIV-1 Pol proteins. Curr. HIV Res., v. 3, n. 1, p. 73-85, 2005. 
HIRSCH, V. M. et al. An African Primate Lentivirus (Sivsm) Closely Related to Hiv-2. Nature, v. 339, n. 6223, p. 389-392, 1989.

HO, D. D.; MOUDGIL, T.; ALAM, M. Quantitation of human immunodeficiency virus type 1 in the blood of infected persons. N. Engl. J. Med., v. 321, n. 24, p. 1621-1625, 1989.

HOLLINGER, F. B. et al. Standardization of sensitive human immunodeficiency virus coculture procedures and establishment of a multicenter quality assurance program for the AIDS Clinical Trials Group. The NIH/NIAID/DAIDS/ACTG Virology Laboratories. J. Clin. Microbiol., v. 30, n. 7, p. 1787-1794, 1992.

HOLMES, E. C.; WOROBEY, M.; RAMBAUT, A. Phylogenetic evidence for recombination in dengue virus. Mol. Biol. Evol., v. 16, n. 3, p. 405-409, 1999.

HRECKA, K. et al. Nef proteins from diverse groups of primate lentiviruses downmodulate CXCR4 to inhibit migration to the chemokine stromal derived factor 1. J. Virol., v. 79, n. 16, p. 10650-10659, 2005.

HU, W. S.; TEMIN, H. M. Genetic consequences of packaging two RNA genomes in one retroviral particle: pseudodiploidy and high rate of genetic recombination. Proc. Natl. Acad. Sci. U.S.A., v. 87, n. 4, p. 1556-1560, 1990a.

HU, W. S.; TEMIN, H. M. Retroviral recombination and reverse transcription. Science, v. 250, n. 4985, p. 1227-1233, 1990 b.

HUANG, M. et al. p6Gag is required for particle production from full-length human immunodeficiency virus type 1 molecular clones expressing protease. J. Virol., v. 69, n. 11, p. 6810-6818, 1995.

HUSMEIER, D.; MCGUIRE, G. Detecting recombination in 4-taxa DNA sequence alignments with Bayesian hidden Markov models and Markov chain Monte Carlo. Mol. Biol. Evol., v. 20, n. 3, p. 315-337, 2003.

HUSMEIER, D.; WRIGHT, F.; MILNE, I. Detecting interspecific recombination with a pruned probabilistic divergence measure. Bioinformatics, v. 21, n. 9, p. 1797-1806, 2005.

JACKS, T. et al. Characterization of ribosomal frameshifting in HIV-1 gag-pol expression. Nature, v. 331, n. 6153, p. 280-283, 1988. 
JAKOBSEN, I. B.; EASTEAL, S. A program for calculating and displaying compatibility matrices as an aid in determining reticulate evolution in molecular sequences. Comput. Appl. Biosci., v. 12, n. 4, p. 291-295, 1996.

JAKOBSEN, I. B.; WILSON, S. R.; EASTEAL, S. The partition matrix: Exploring variable phylogenetic signals along nucleotide sequence alignments. Mol. Biol. Evol., v. 14, n. 5, p. 474-484, 1997.

JANINI, L. et al. Identification of single and dual infections with distinct subtypes of human immunodeficiency virus type 1 by using restriction fragment length polymorphism analysis. Virus Genes, v. 13, n. 1, p. 69-81, 1996.

JANINI, L. et al. Horizontal and Vertical Transmission of Human Immunodeficiency Virus Type 1 Dual Infections Caused by Viruses of Subtypes B and C. J. Infect. Dis., v. 177, n. 1, p. 227-231, 1998.

JENSEN, M. A. et al. Improved coreceptor usage prediction and genotypic monitoring of R5to-X4 transition by motif analysis of human immunodeficiency virus type 1 env V3 loop sequences. J. Virol., v. 77, n. 24, p. 13376-13388, 2003.

JERE, A. et al. Role of HIV-1 Nef protein for virus replication in vitro. Microbes Infect., v. 12 , n. 1, p. 65-70, 2010.

JETZT, A. et al. High rate of recombination throughout the human immunodeficiency virus type 1 genome. J. Virol., v. 74, n. 3, p. 1234-1240, 2000.

JOHNSON, M. S. et al. Computer analysis of retroviral pol genes: assignment of enzymatic functions to specific sequences and homologies with nonviral enzymes. Proc. Natl. Acad. Sci. U. S. A., v. 83, n. 20, p. 7648-7652, 1986.

JOST, S. et al. A patient with HIV-1 superinfection. N. Engl. J. Med., v. 347, n. 10, p. 731736, 2002.

JOUVENET, N. et al. Broad-spectrum inhibition of retroviral and filoviral particle release by tetherin. J. Virol., v. 83, n. 4, p. 1837-1844, 2009.

JOWETT, J. B. et al. The human immunodeficiency virus type $1 \mathrm{vpr}$ gene arrests infected T cells in the G2 + M phase of the cell cycle. J. Virol., v. 69, n. 10, p. 6304-6313, 1995. 
JUNG, A. et al. Recombination: Multiply infected spleen cells in HIV patients. Nature, v. 418, n. 6894, p. 144, 2002.

KARN, J. et al. RNA binding by the tat and rev proteins of HIV-1. Biochimie, v. 73, n. 1, p. 9-16, 1991.

KHAN, M. A. et al. Human immunodeficiency virus type I Vif protein is packaged into the nucleoprotein complex through an interaction with viral genomic RNA. J. Virol., v. 75, n. 16, p. 7252-7265, 2001.

KLOTMAN, M. E. et al. Kinetics of Expression of Multiply Spliced Rna in Early HumanImmunodeficiency-Virus Type-1 Infection of Lymphocytes and Monocytes. Proc. Natl. Acad. Sci. U. S. A., v. 88, n. 11, p. 5011-5015, 1991.

KOZACZYNSKA, K. et al. HIV-1 sequence evolution in vivo after superinfection with three viral strains. Retrovirology, v. 4, p. 59, 2007.

KOZAL, M. J. et al. Extensive polymorphisms observed in HIV-1 clade B protease gene using high-density oligonucleotide arrays. Nat. Med., v. 2, n. 7, p. 753-759, 1996.

KREBS, F. C. et al. Lentiviral LTR-directed expression, sequence variation, and disease Pathogenesis. In: KUIKEN, C. et al. (Ed.). HIV Sequence Compendium. Los Alamos, NM: Theoretical Biology and Biophysics Group, Los Alamos National Laboratory, 2001. p. 29-70.

KWONG, P. D. et al. Structure of an HIV gp120 envelope glycoprotein in complex with the CD4 receptor and a neutralizing human antibody. Nature, v. 393, n. 6686, p. 648-59, 1998.

LAL, R.; CHAKRABARTI, S.; YANG, C. Impact of genetic diversity of HIV-1 on diagnosis, antiretroviral therapy \& vaccine development. Indian J. Med. Res., v. 121, n. 4, p. 287-314, 2005.

LANDAU, N. R.; WARTON, M.; LITTMAN, D. R. The envelope glycoprotein of the human immunodeficiency virus binds to the immunoglobulin-like domain of CD4. Nature, v. 334, n. 6178, p. 159-162, 1988.

LARKIN, M. A. et al. Clustal W and Clustal X version 2.0. Bioinformatics, v. 23, n. 21, p. 2947-2948, 2007. 
LATAILlADE, M.; CHIARELLA, J.; KOZAL, M. J. Natural polymorphism of the HIV-1 integrase gene and mutations associated with integrase inhibitor resistance. Antivir. Ther., v. 12, n. 4, p. 563-570, 2007.

LE GRICE, S. F. et al. Subunit-selective mutagenesis indicates minimal polymerase activity in heterodimer-associated p51 HIV-1 reverse transcriptase. EMBO J., v. 10, n. 12, p. 39053911, 1991.

LE ROUZIC, E.; BENICHOU, S. The Vpr protein from HIV-1: distinct roles along the viral life cycle. Retrovirology, v. 2, n. 11, p. $13,2005$.

LEAL et al. Evolutionary Dynamics of HIV-1 BF and CB Recombinants and Its Parental Counterparts in South America. Retrovirology: Res. and Treat., v. 2008, n. RRT-1-Leal-et-al, p. 1, 2008a.

LEAL, E. et al. Molecular and structural characterization of HIV-1 subtype B Brazilian isolates with GWGR tetramer at the tip of the V3-loop. Virology, v. 381, n. 2, p. 222-229, 2008b.

LEMEY, P. et al. Identifying recombinants in human and primate immunodeficiency virus sequence alignments using quartet scanning. BMC Bioinformatics, v. 10, p. 126, 2009.

LEMEY, P.; POSADA, D. Introduction to recombination detection. In: VANDAMME, A. M. et al. (Ed.). The Phylogenetic Handbook. 2nd ed. Cambridge: Cambridge University Press, 2009. cap. 15, p. 493-518.

LEVIN, A.; LOYTER, A.; BUKRINSKY, M. Strategies to inhibit viral protein nuclear import: HIV-1 as a target. Biochim. Biophys. Acta, 2010. In press.

LI, M. et al. Retroviral DNA integration: reaction pathway and critical intermediates. EMBO J., v. 25, n. 6, p. 1295-304, 2006.

LIN, C. W.; ENGELMAN, A. The barrier-to-autointegration factor is a component of functional human immunodeficiency virus type 1 preintegration complexes. J. Virol., v. 77, n. 8, p. 5030-5036, 2003.

LIU, H. et al. The Vif protein of human and simian immunodeficiency viruses is packaged into virions and associates with viral core structures. J. Virol., v. 69, n. 12, p. 7630-7668, 1995. 
LODI, P. J. et al. Solution structure of the DNA binding domain of HIV-1 integrase. Biochemistry, v. 34, n. 31, p. 9826-9833, 1995.

LOLE, K. S. et al. Full-length human immunodeficiency virus type 1 genomes from subtype C-infected seroconverters in India, with evidence of intersubtype recombination. J. Virol., v. 73, n. 1, p. 152-160, 1999.

LOUIS, J. M. et al. Kinetics and mechanism of autoprocessing of human immunodeficiency virus type 1 protease from an analog of the Gag-Pol polyprotein. Proc. Natl. Acad. Sci. U. S. A., v. 91 , n. 17 , p. $7970-7974,1994$.

LOW, A. et al. Natural polymorphisms of human immunodeficiency virus type 1 integrase and inherent susceptibilities to a panel of integrase inhibitors. Antimicrob. Agents Chemother., v. 53, n. 10, p. 4275-4282, 2009.

MAERTENS, G. N.; HARE, S.; CHEREPANOV, P. The mechanism of retroviral integration from X-ray structures of its key intermediates. Nature, v. 468, n. 7321, p. 326-329, 2010.

MALET, I. et al. Mutations associated with failure of raltegravir treatment affect integrase sensitivity to the inhibitor in vitro. Antimicrob. Agents Chemother., v. 52, n. 4, p. 13511358, 2008.

MALIM, M. H. et al. The HIV-1 rev trans-activator acts through a structured target sequence to activate nuclear export of unspliced viral mRNA. Nature, v. 338, n. 6212, p. 254-257, 1989.

MANSKY, L. M. The mutation rate of human immunodeficiency virus type 1 is influenced by the vpr gene. Virology, v. 222, n. 2, p. 391-400, 1996.

MARGOTTIN, F. et al. A novel human WD protein, h-beta TrCp, that interacts with HIV-1 Vpu connects CD4 to the ER degradation pathway through an F-box motif. Mol. Cell, v. 1, n. 4, p. 565-574, 1998.

MARKOWITZ, M. et al. Rapid and durable antiretroviral effect of the HIV-1 Integrase inhibitor raltegravir as part of combination therapy in treatment-naive patients with HIV-1 infection: results of a 48-week controlled study. J. Acquir. Immune Defic. Syndr., v. 46, n. 2, p. 125-133, 2007.

MARTIN, D.; RYBICKI, E. RDP: detection of recombination amongst aligned sequences. Bioinformatics, v. 16, n. 6, p. 562-563, 2000. 
MARTIN, D. P. et al. RDP3: a flexible and fast computer program for analyzing recombination. Bioinformatics, v. 26, n. 19, p. 2462-2463, 2010.

MARTIN, D. P. et al. A modified bootscan algorithm for automated identification of recombinant sequences and recombination breakpoints. AIDS Res. Hum. Retroviruses, v. 21, n. 1, p. 98-102, 2005.

MARTIN, D. P.; WILLIAMSON, C.; POSADA, D. RDP2: recombination detection and analysis from sequence alignments. Bioinformatics, v. 21, n. 2, p. 260-262, 2005.

MASCARENHAS, A. P.; MUSIER-FORSYTH, K. The capsid protein of human immunodeficiency virus: interactions of HIV-1 capsid with host protein factors. FEBS J., v. 276, n. 21, p. 6118-6127, 2009.

MASUR, H. et al. An outbreak of community-acquired Pneumocystis carinii pneumonia: initial manifestation of cellular immune dysfunction. N. Engl. J. Med., v. 305, n. 24, p. 14311438, 1981.

MATTIUZZO, G.; IVOL, S.; TAKEUCHI, Y. Regulation of Porcine Endogenous Retrovirus Release by Porcine and Human Tetherins. J. Virol., v. 84, n. 5, p. 2618-2622, 2010.

MAYNARD SMITH, J. Analyzing the mosaic structure of genes. J. Mol. Evol., v. 34, n. 2, p. 126-129, 1992.

MAYNARD SMITH, J. The detection and measurement of recombination from sequence data. Genetics, v. 153, n. 2, p. 1021-1027, 1999.

MCCOLL, D. J. et al. Resistance and cross-resistance to first generation integrase inhibitors: insights from a Phase II study of elvitegravir (GS-9137). Antivir. Ther., v. 12, n. 5, p. S11S11, 2007.

MCGUIRE, G.; WRIGHT, F. TOPAL 2.0: improved detection of mosaic sequences within multiple alignments. Bioinformatics, v. 16, n. 2, p. 130-134, 2000.

MELONI, S. T. et al. Distinct human immunodeficiency virus type 1 subtype A virus circulating in West Africa: sub-subtype A3. J. Virol., v. 78, n. 22, p. 12438-12445, 2004. 
MILLER, M. D.; FARNET, C. M.; BUSHMAN, F. D. Human immunodeficiency virus type 1 preintegration complexes: studies of organization and composition. J. Virol., v. 71, n. 7, p. 5382-5390, 1997.

MILLER, M. D. et al. The human immunodeficiency virus-1 nef gene product: a positive factor for viral infection and replication in primary lymphocytes and macrophages. J. Exp. Med., v. 179, n. 1, p. 101-113, 1994.

MININ, V. N. et al. Dual multiple change-point model leads to more accurate recombination detection. Bioinformatics, v. 21, n. 13, p. 3034-3042, 2005.

MISUMI, S. et al. Uncoating of Human Immunodeficiency Virus Type 1 Requires Prolyl Isomerase Pin1. J. Biol. Chem., v. 285, n. 33, p. 25185-25195, 2010.

MITCHELL, R. S. et al. Retroviral DNA integration: ASLV, HIV, and MLV show distinct target site preferences. PLoS Biol., v. 2, n. 8, p. 1127-1137, 2004.

MIYAUCHI, K. et al. HIV enters cells via endocytosis and dynamin-dependent fusion with endosomes. Cell, v. 137, n. 3, p. 433-444, 2009.

MORGADO, M. G. et al. Molecular epidemiology of HIV-1 in Brazil: high prevalence of HIV-1 subtype B and identification of an HIV-1 subtype D infection in the city of Rio de Janeiro, Brazil. J. Acquir. Immune Defic. Syndr. Hum. Retrovirol., v. 18, n. 5, p. 488-494, 1998.

MORNER, A. et al. Primary human immunodeficiency virus type 2 (HIV-2) isolates, like HIV-1 isolates, frequently use CCR5 but show promiscuity in coreceptor usage. J. Virol., v. 73, n. 3, p. 2343-2349, 1999.

MOUTOUH, L.; CORBEIL, J.; RICHMAN, D. D. Recombination leads to the rapid emergence of HIV-1 dually resistant mutants under selective drug pressure. Proc. Natl. Acad. Sci. U. S. A., v. 93, n. 12, p. 6106-6111, 1996.

NADAI, Y. et al. Protocol for Nearly Full-Length Sequencing of HIV-1 RNA from Plasma. PLoS ONE, v. 3, n. 1, p. e1420, 2008.

NEHER, R. A.; LEITNER, T. Recombination rate and selection strength in HIV intra-patient evolution. PLoS Comput. Biol., v. 6, n. 1, p. e1000660, 2010. 
NEIL, S. J. D.; ZANG, T.; BIENIASZ, P. D. Tetherin inhibits retrovirus release and is antagonized by HIV-1 Vpu. Nature, v. 451, n. 7177, p. 425-430, 2008.

NJAI, H. F. et al. The predominance of Human Immunodeficiency Virus type 1 (HIV-1) circulating recombinant form 02 (CRF02_AG) in West Central Africa may be related to its replicative fitness. Retrovirology, v. 3, p. 40, 2006.

NORA, T. et al. Contribution of recombination to the evolution of human immunodeficiency viruses expressing resistance to antiretroviral treatment. J. Virol., v. 81, n. 14, p. 7620-7628, 2007.

ONAFUWA-NUGA, A.; TELESNITSKY, A. The remarkable frequency of human immunodeficiency virus type 1 genetic recombination. Microbiol. Mol. Biol. Rev., v. 73, n. 3, p. 451-480, 2009.

OSMANOV, S. et al. Estimated global distribution and regional spread of HIV-1 genetic subtypes in the year 2000. J. Acquir. Immune Defic. Syndr., v. 29, n. 2, p. 184-190, 2002.

PADIDAM, M.; SAWYER, S.; FAUQUET, C. M. Possible emergence of new geminiviruses by frequent recombination. Virology, v. 265, n. 2, p. 218-225, 1999.

PANDO, M. A. et al. First report of an HIV-1 triple recombinant of subtypes B, C and F in Buenos Aires, Argentina. Retrovirology, v. 3, p. 59, 2006.

PARDINI, M. I. et al. Boosting virology in Brazil. PLoS Biol., v. 6, n. 3, p. 428-429, 2008.

PASSAES, C. B. et al. Lack of Primary Mutations Associated With Integrase Inhibitors Among HIV-1 Subtypes B, C, and F Circulating in Brazil. J. Acquir. Immune Defic. Syndr., v. 51, n. 1, p. 7-12, 2009a.

PASSAES, C. P. et al. Near full-length genome characterization of HIV type 1 unique BC recombinant forms from Southern Brazil. AIDS Res. Hum. Retroviruses, v. 25, n. 12, p. 1339-1344, 2009b.

PAXTON, W.; CONNOR, R. I.; LANDAU, N. R. Incorporation of Vpr into human immunodeficiency virus type 1 virions: requirement for the p6 region of gag and mutational analysis. J. Virol., v. 67, n. 12, p. 7229-7237, 1993. 
PEARL, L. H.; TAYLOR, W. R. A structural model for the retroviral proteases. Nature, v. 329, n. 6137, p. 351-354, 1987.

PERELSON, A. S. et al. HIV-1 dynamics in vivo: virion clearance rate, infected cell lifespan, and viral generation time. Science, v. 271, n. 5255, p. 1582-1586, 1996.

PERMANYER, M.; BALLANA, E.; ESTE, J. A. Endocytosis of HIV: anything goes. Trends Microbiol., v. 18, n. 12, p. 543-551, 2010.

PIANTADOSI, A. et al. Chronic HIV-1 infection frequently fails to protect against superinfection. PLoS Pathog., v. 3, n. 11, p. e177, 2007.

PIENIAZEK, D. et al. HIV-1 patients may harbor viruses of different phylogenetic subtypes: implications for the evolution of the HIV/AIDS pandemic. Emerg. Infect. Dis., v. 1, n. 3, p. 86-88, 1995.

PLANTIER, J.-C. et al. A new human immunodeficiency virus derived from gorillas. Nat. Med., p. 1-2, 2009.

POLlaRD, V. W.; MALIM, M. H. The HIV-1 Rev protein. Annu. Rev. Microbiol., v. 52, p. 491-532, 1998.

POND, S. L. K. et al. Automated phylogenetic detection of recombination using a genetic algorithm. Mol. Biol. Evol., v. 23, n. 10, p. 1891-1901, 2006.

POPOV, S. et al. Viral protein R regulates nuclear import of the HIV-1 pre-integration complex. EMBO J., v. 17, n. 4, p. 909-917, 1998.

POSADA, D.; CRANDALL, K. A. Evaluation of methods for detecting recombination from DNA sequences: Computer simulations. Proc. Natl. Acad. Sci. U. S. A., v. 98, n. 24, p. 13757-13762, 2001.

POSADA, D.; CRANDALL, K. A.; HOLMES, E. C. Recombination in evolutionary genomics. Annu. Rev. Genet., v. 36, p. 75-97, 2002.

PRESTON, B. D.; POIESZ, B. J.; LOEB, L. A. Fidelity of HIV-1 reverse transcriptase. Science, v. 242, n. 4882, p. 1168-1171, 1988. 
RABONI, S. M. et al. Molecular epidemiology of HIV-1 clades in Southern Brazil. Mem. Inst. Oswaldo Cruz, v. 105, n. 8, p. 1044-1049, 2010.

RAMBAUT, A. Se-A1: Sequence aligment editor. 1996. Disponível em: <http://evolve.zoo.ox.ac.uk>. Acesso em: 01 Jan. 2007.

RAMIREZ, B. C. et al. Implications of recombination for HIV diversity. Virus Res., v. 134, n. 1-2, p. 64-73, 2008.

RAMIREZ DE ARELLANO, E. et al. New findings on transcription regulation across different HIV-1 subtypes. AIDS Rev., v. 8, n. 1, p. 9-16, 2006.

RAMOS, A. et al. Intersubtype human immunodeficiency virus type 1 superinfection following seroconversion to primary infection in two injection drug users. J. Virol., v. 76, n. 15 , p. 7444-7452, 2002.

REEVES, J. D.; DOMS, R. W. Human immunodeficiency virus type 2. J. Gen. Virol., v. 83, n. Pt 6, p. 1253-1265, 2002.

REPETTO, G.; DEL PESO, A.; ZURITA, J. L. Neutral red uptake assay for the estimation of cell viability/cytotoxicity. Nat. Protoc., v. 3, n. 7, p. 1125-1131, 2008.

REUMAN, E. C. et al. Panel of prototypical raltegravir-resistant infectious molecular clones in a novel integrase-deleted cloning vector. Antimicrob. Agents Chemother., v. 54, n. 2, p. 934-936, 2010.

ROBERT-GUROFF, M. et al. Structure and Expression of Tat-Specific, Rev-Specific, and Nef-Specific Transcripts of Human-Immunodeficiency-Virus Type-1 in Infected Lymphocytes and Macrophages. J. Virol., v. 64, n. 7, p. 3391-3398, 1990.

ROBERTS, J. D.; BEBENEK, K.; KUNKEL, T. A. The accuracy of reverse transcriptase from HIV-1. Science, v. 242, n. 4882, p. 1171-1173, 1988.

ROBERTSON, D. L. et al. HIV-1 nomenclature proposal. Science, v. 288, n. 5463, p. 55-56, 2000.

RUBEN, S. et al. Structural and functional characterization of human immunodeficiency virus tat protein. J. Virol., v. 63, n. 1, p. 1-8, 1989. 
SA-FERREIRA, J. A. et al. Human immunodeficiency virus-1 subtypes and antiretroviral drug resistance profiles among drug-naive Brazilian blood donors. Transfusion, v. 47, n. 1, p. 97-102, 2007.

SA FILHO, D. et al. Analysis of full-length human immunodeficiency virus type 1 genome reveals a variable spectrum of subtypes B and f recombinants in Sao Paulo, Brazil. AIDS Res. Hum. Retroviruses, v. 21, n. 2, p. 145-151, 2005.

SABINO, E. C. et al. Identification of human immunodeficiency virus type 1 envelope genes recombinant between subtypes $\mathrm{B}$ and $\mathrm{F}$ in two epidemiologically linked individuals from Brazil. J. Virol., v. 68, n. 10, p. 6340-6346, 1994.

SAKUMA, T. et al. Inhibition of Lassa and Marburg virus production by tetherin. J. Virol., v. 83 , n. 5 , p. $2382-2385,2009$.

SALMINEN, M.; MARTIN, D. Detecting and characterizing individual recombination events. In: VANDAMME, A. M. et al (Ed.). The Phylogenetic Handbook. 2nd ed. Cambridge: Cambridge University Press, 2009. cap. 16, p.519-548.

SALMINEN, M. O. et al. Identification of breakpoints in intergenotypic recombinants of HIV type 1 by bootscanning. AIDS Res. Hum. Retroviruses, v. 11, n. 11, p. 1423-1425, 1995.

SANABANI, S. et al. Analysis of the near full length genomes of HIV-1 subtypes B, F and BF recombinant from a cohort of 14 patients in Sao Paulo, Brazil. Infect. Genet. Evol., v. 6, n. 5, p. 368-377, 2006.

SANABANI, S. et al. Characterization and frequency of a newly identified HIV-1 BF1 intersubtype circulating recombinant form in Sao Paulo, Brazil. Virol. J., v. 7, p. 74, 2010.

SANCHEZ, V. et al. Performance of genotypic algorithms for predicting HIV-1 tropism measured against the enhanced-sensitivity Trofile coreceptor tropism assay. J. Clin. Microbiol., v. 48, n. 11, p. 4135-4139, 2010.

SANTOS, A. F. et al. Characterization of a new circulating recombinant form comprising HIV-1 subtypes C and B in southern Brazil. AIDS, v. 20, n. 16, p. 2011-2019, 2006. 
SASTRY, K. J. et al. Expression of human immunodeficiency virus type I tat results in down-regulation of bcl-2 and induction of apoptosis in hematopoietic cells. Oncogene, v. 13, n. 3, p. 487-493, 1996.

SAWYER, S. Statistical Tests for Detecting Gene Conversion. Mol. Biol. Evol., v. 6, n. 5, p. 526-538, 1989.

SCHRÖDER, A. R. W. et al. HIV-1 integration in the human genome favors active genes and local hotspots. Cell, v. 110, n. 4, p. 521-529, 2002.

SCHULTZ, A. K. et al. jpHMM: Improving the reliability of recombination prediction in HIV-1. Nucleic Acids Res., v. 37, p. 647-651, 2009.

SCHULTZ, A. K. et al. A jumping profile Hidden Markov Model and applications to recombination sites in HIV and HCV genomes. BMC Bioinformatics, v. 7, p. 265, 2006.

SCHWARTZ, M. D.; FIORE, D.; PANGANIBAN, A. T. Distinct functions and requirements for the Cys-His boxes of the human immunodeficiency virus type 1 nucleocapsid protein during RNA encapsidation and replication. J. Virol., v. 71, n. 12, p. 9295-9305, 1997.

SCHWARTZ, O. et al. Endocytosis of major histocompatibility complex class I molecules is induced by the HIV-1 Nef protein. Nat. Med., v. 2, n. 3, p. 338-342, 1996.

SEELAMGARI, A. et al. Role of viral regulatory and accessory proteins in HIV-1 replication. Front. Biosci., v. 9, p. 2388-2413, 2004.

SHARMA, V. et al. HIV-1 tat induces the expression of a new hematopoietic cell-specific transcription factor and downregulates MIP-1 alpha gene expression in activated T-cells. Biochem. Biophys. Res. Commun., v. 223, n. 3, p. 526-533, 1996.

SHARP, P. M.; HAHN, B. H. The evolution of HIV-1 and the origin of AIDS. Phil Trans Biol Sci., v. 365, n. 1552, p. 2487-2494, 2010.

SHEEHY, A. M.; GADDIS, N. C.; MALIM, M. H. The antiretroviral enzyme APOBEC3G is degraded by the proteasome in response to HIV-1 Vif. Nat. Med., v. 9, n. 11, p. 1404-1407, 2003.

SIEPEL, A. C. et al. A computer program designed to screen rapidly for HIV type 1 intersubtype recombinant sequences. AIDS Res. Hum. Retroviruses, v. 11, n. 11, p. 1413$1416,1995$. 
SIMON-LORIERE, E. et al. RNA Structures Facilitate Recombination-Mediated Gene Swapping in HIV-1. J. Virol., v. 84, n. 24, p. 12675-12682, 2010.

SIMON, F. et al. Identification of a new human immunodeficiency virus type 1 distinct from group M and group O. Nat. Med., v. 4, n. 9, p. 1032-1037, 1998.

SNEATH, P. H. A.; SACKIN, M. J.; AMBLER, R. P. Detecting Evolutionary Incompatibilities from Protein Sequences. Syst. Zool., v. 24, n. 3, p. 311-332, 1975.

SOARES, E. A. J. M. et al. HIV-1 subtype C dissemination in southern Brazil. AIDS, v. 19, p. S81-S86, 2005. Suppl 4.

SOARES, M. et al. A specific subtype $\mathrm{C}$ of human immunodeficiency virus type 1 circulates in Brazil. AIDS, v. 17, n. 1, p. 11-21, 2003.

STEAIN, M. C. et al. HIV-1 co-infection, superinfection and recombination. Sex. Health, v. 1, n. 4, p. 239-250, 2004.

STEFANI, M. M. A. et al. Molecular screening shows extensive HIV-1 genetic diversity in Central West Brazil. J. Clin. Virol., v. 39, n. 3, p. 205-209, 2007.

STREBEL, K. et al. The HIV 'A' (sor) gene product is essential for virus infectivity. Nature, v. 328, n. 6132, p. 728-730, 1987.

STREBEL, K. et al. Molecular and biochemical analyses of human immunodeficiency virus type 1 vpu protein. J. Virol., v. 63, n. 9, p. 3784-3791, 1989.

STREECK, $\mathrm{H}$. et al. Immune-driven recombination and loss of control after HIV superinfection. J. Exp. Med., v. 205, n. 8, p. 1789-1796, 2008.

STREMLAU, M. et al. Specific recognition and accelerated uncoating of retroviral capsids by the TRIM5 alpha restriction factor. Proc. Natl. Acad. Sci. U. S. A., v. 103, n. 14, p. 55145519, 2006.

STUHLMANN, H.; BERG, P. Homologous recombination of copackaged retrovirus RNAs during reverse transcription. J. Virol., v. 66, n. 4, p. 2378-2388, 1992. 
STUMPTNER-CUVELETTE, P. et al. HIV-1 Nef impairs MHC class II antigen presentation and surface expression. Proc. Natl. Acad. Sci. U. S. A., v. 98, n. 21, p. 12144-12149, 2001.

SUCHARD, M. A. et al. Oh brother, where art thou? A Bayes factor test for recombination with uncertain heritage. Syst. Biol., v. 51, n. 5, p. 715-728, 2002.

SUCUPIRA, M. C. A. et al. High Levels of Primary Antiretroviral Resistance Genotypic Mutations And B/F Recombinants in Santos, Brazil. AIDS Patient Care STDS, v. 21, n. 2, p. 116-128, 2007.

SWIGUT, T.; SHOHDY, N.; SKOWRONSKI, J. Mechanism for down-regulation of CD28 by Nef. EMBO J., v. 20, n. 7, p. 1593-1604, 2001.

SWISS INSTITUTE OF BIOINFORMATICS. Título [2011]. Disponível em: http://expasy.org/viralzone/all_by_species/7.html . Acesso em: 10 Jan. 2011.

TAKEHISA, J. et al. Triple HIV-1 infection with group O and Group M of different clades in a single Cameroonian AIDS patient. J. Acquir. Immune Defic. Syndr. Hum. Retrovirol., v. 14, n. 1, p. 81-82, 1997.

TANURI, A. et al. HIV-1 subtypes among blood donors from Rio de Janeiro, Brazil. J. Acquir. Immune Defic. Syndr. Hum. Retrovirol., v. 20, n. 1, p. 60-66, 1999.

TAYLOR, B. S. et al. The challenge of HIV-1 subtype diversity. N. Engl. J. Med., v. 358, n. 15, p. $1590-1602,2008$

TEBIT, D. M.; ARTS, E. J. Tracking a century of global expansion and evolution of HIV to drive understanding and to combat disease. Lancet Infect. Dis., v. 11, n. 1, p. 45-56, 2011.

TEIXEIRA, D. et al. The detection of in vivo and in vitro HIV type $1 \mathrm{~B} / \mathrm{F}$ profiles in Brazil using a real-time PCR assay for five HIV type 1 genomic regions. AIDS Res. Hum. Retroviruses, v. 26, n. 9, p. 981-990, 2010.

TOKAREV, A. et al. Antiviral activity of the interferon-induced cellular protein BST2/tetherin. AIDS Res. Hum. Retroviruses, v. 25, n. 12, p. 1197-1210, 2009.

TOMASINI-GROTTO, R.-M. et al. Variability of the conserved V3 loop tip motif in HIV-1 subtype B isolates collected from Brazilian and French patients. Braz. J. Microbiol., v. 41, p. 720-728, 2010. 
TRIQUES, K. et al. High diversity of HIV-1 subtype F strains in Central Africa. Virology, v. 259, n. 1, p. 99-109, 1999.

UNITED NATIONS PROGRAM ON HIV/AIDS/WORLD HEALTH ORGANIZATION. Report on the global AIDS epidemic. 2010. Disponível em: <http://www.unaids.org>. Acesso em: 10 Dec. 2010.

VALLARI, A. et al. Four New HIV-1 Group N Isolates from Cameroon: Prevalence Continues to Be Low. AIDS Res. Hum. Retroviruses, v. 26, n. 1, p. 109-115, 2010.

VAN LAETHEM, K. et al. A genotypic assay for the amplification and sequencing of integrase from diverse HIV-1 group M subtypes. J. Virol. Methods, v. 153, n. 2, p. 176-181, 2008 .

VERAS, N. M. C. et al. HIV type 1 genetic variability in Central Brazil. AIDS Res. Hum. Retroviruses, v. 23, n. 12, p. 1481-1489, 2007.

VICENTE, A. C. P. et al. The HIV epidemic in the amazon basin is driven by prototypic and recombinant HIV-1 subtypes B and F. J. Acquir. Immune Defic. Syndr., v. 23, n. 4, p. 327$331,2000$.

VON SCHWEDLER, U. K. et al. The protein network of HIV budding. Cell, v. 114, n. 6, p. 701-713, 2003.

WATTS, J. M. et al. Architecture and secondary structure of an entire HIV-1 RNA genome. Nature, v. 460, n. 7256, p. 711, 2009.

WEI, X. et al. Viral dynamics in human immunodeficiency virus type 1 infection. Nature, v. 373, n. 6510, p. 117-122, 1995.

WEILLER, G. F. et al. Recombination signature of germline immunoglobulin variable genes. Immunol. Cell Biol., v. 76, n. 2, p. 179-185, 1998.

WILLEY, R. L. et al. Biosynthesis, cleavage, and degradation of the human immunodeficiency virus 1 envelope glycoprotein gp160. Proc. Natl. Acad. Sci. U. S. A., v. 85 , n. 24, p. 9580-9584, 1988.

WILLEY, R. L. et al. Human immunodeficiency virus type $1 \mathrm{Vpu}$ protein induces rapid degradation of CD4. J. Virol., v. 66, n. 12, p. 7193-7200, 1992. 
WILSON, W. et al. Hiv Expression Strategies - Ribosomal Frameshifting Is Directed by a Short Sequence in Both Mammalian and Yeast Systems. Cell, v. 55, n. 6, p. 1159-1169, 1988.

WISSING, S.; GALLOWAY, N. L. K.; GREENE, W. C. HIV-1 Vif versus the APOBEC3 cytidine deaminases: An intracellular duel between pathogen and host restriction factors. Mol. Aspects Med., v. 31, n. 5, p. 383-397, 2010.

WU, L. et al. CD4-induced interaction of primary HIV-1 gp120 glycoproteins with the chemokine receptor CCR-5. Nature, v. 384, n. 6605, p. 179-183, 1996.

WYATT, R.; SODROSKI, J. The HIV-1 envelope glycoproteins: fusogens, antigens, and immunogens. Science, v. 280, n. 5371, p. 1884-1888, 1998.

ZHANG, M. et al. The role of recombination in the emergence of a complex and dynamic HIV epidemic. Retrovirology, v. 7, p. 25, 2010.

ZHANG, M. et al. jpHMM at GOBICS: a web server to detect genomic recombinations in HIV-1. Nucleic Acids Res., v. 34, p. 463-465, 2006.

ZHU, T. et al. Evidence for coinfection by multiple strains of human immunodeficiency virus type 1 subtype B in an acute seroconvertor. J. Virol., v. 69, n. 2, p. 1324-1327, 1995.

ZHUANG, J. et al. Human immunodeficiency virus type 1 recombination: rate, fidelity, and putative hot spots. J. Virol., v. 76, n. 22, p. 11273-11282, 2002.

ZWICKL, D. J. Genetic algorithm approaches for the phylogenetic analysis of large biological sequence datasets under the maximum likelihood criterion. 115 p. 2006. Doctoral Thesis (Doctor of Philosophy) - School of Biological Sciences, The University of Texas, Austin, 2006. 
ANEXO A- TABELA SUPLEMENTAR 1 
TABELA S1- Número de acesso para as sequências de integrase de amostras brasileiras disponíveis

\begin{tabular}{|c|c|c|c|c|c|}
\hline $\begin{array}{l}\text { Subtipo } \\
\text { Integrase }\end{array}$ & $\begin{array}{c}\text { Número } \\
\text { de acesso }\end{array}$ & $\begin{array}{c}\text { Ano } \\
\text { amostragem }\end{array}$ & $\begin{array}{c}\text { Subtipo } \\
\text { Integrase }\end{array}$ & $\begin{array}{c}\text { Número } \\
\text { de acesso }\end{array}$ & $\begin{array}{c}\text { Ano } \\
\text { amostragem }\end{array}$ \\
\hline B & EF150616 & 2000 & B & HM026781 & 2003 \\
\hline B & EF150615 & 2002 & B & HM026780 & 2003 \\
\hline B & EF150614 & 2001 & B & HM026779 & 2003 \\
\hline B & EF150613 & 2001 & B & HM026778 & 2003 \\
\hline B & EF150612 & 2000 & B & HM026777 & 2003 \\
\hline B & EF150611 & 2000 & B & HM026776 & 2003 \\
\hline B & EF150610 & 2000 & B & HM026775 & 2003 \\
\hline B & EF150609 & 2000 & B & HM026774 & 2002 \\
\hline B & EF150608 & 2000 & B & HM026773 & 2002 \\
\hline B & EF150607 & 2000 & B & HM026772 & 2002 \\
\hline B & EF150606 & 2001 & B & HM026771 & 2003 \\
\hline B & EF150605 & 2001 & B & HM026770 & 2003 \\
\hline B & EF150604 & 2001 & B & HM026769 & 2003 \\
\hline B & EF150603 & 2001 & B & HM026768 & 2003 \\
\hline B & EF150602 & 2000 & B & HM026767 & 2003 \\
\hline B & EF150600 & 2002 & B & HM026766 & 2003 \\
\hline B & EF150599 & 2003 & B & HM026765 & 2003 \\
\hline B & EF150598 & 2002 & B & HM026764 & 2003 \\
\hline B & EF150596 & 2002 & B & HM026763 & 2003 \\
\hline B & EF150595 & 2003 & B & HM026762 & 2003 \\
\hline B & EF150594 & 2003 & B & HM026761 & 2003 \\
\hline B & EF150593 & 2003 & B & HM026760 & 2003 \\
\hline B & EF150592 & 2003 & B & HM439762 & 2002 \\
\hline B & EF150590 & 2002 & B & HM439761 & 2004 \\
\hline B & EF150588 & 2002 & B & HM439760 & 2003 \\
\hline B & EF150587 & 2002 & B & HM439747 & 2005 \\
\hline B & EF150586 & 2002 & B & HM439743 & 2003 \\
\hline B & EF150585 & 2002 & B & HM439741 & 2002 \\
\hline B & EF150584 & 2002 & B & HM439759 & 2004 \\
\hline B & EF150582 & 2002 & B & HM439758 & 2004 \\
\hline B & EF150581 & 2002 & B & HM439757 & 2004 \\
\hline B & EF150580 & 2002 & B_BF & AY455784 & 1994 \\
\hline B & EF150579 & 2002 & B_BF1 & DQ085870 & 1999 \\
\hline B & EF150578 & 2002 & B_BF1 & DQ085869 & 1999 \\
\hline B & EF150577 & 2002 & B_BF1 & DQ085868 & 1999 \\
\hline B & EF150576 & 2002 & B_BF1 & AF005495 & 1993 \\
\hline B & EF150575 & 2002 & B_28BF & DQ085872 & 1999 \\
\hline B & EF150574 & 2002 & B_28BF & DQ085874 & 1999 \\
\hline B & EF150573 & 2002 & B_39BF & EU735536 & 2003 \\
\hline B & EF150572 & 2002 & B_39BF & EU735535 & 2004 \\
\hline B & EF150571 & 2002 & B_39BF & EU735534 & 2003 \\
\hline B & EF150570 & 2002 & $\mathrm{~F}$ & HM026862 & 2000 \\
\hline B & EF150568 & 2002 & F & HM026861 & 2000 \\
\hline
\end{tabular}




\begin{tabular}{|c|c|c|c|c|}
\hline B & EF150567 & 2002 & $\mathrm{~F}$ & HМ026860 \\
\hline B & EF150566 & 2002 & $\mathrm{~F}$ & HM026859 \\
\hline B & EF150565 & 2002 & $\mathrm{~F}$ & HM026858 \\
\hline B & EF150564 & 2002 & $\mathrm{~F}$ & HM026857 \\
\hline B & EF150563 & 2002 & $\mathrm{~F}$ & HМ026856 \\
\hline B & EF150562 & 2002 & F & HМ026855 \\
\hline B & EF150561 & 2002 & F & HМ026854 \\
\hline B & EF150559 & 2002 & $\mathrm{~F}$ & HМ026853 \\
\hline B & EF150558 & 2002 & $\mathrm{~F}$ & HM026852 \\
\hline B & EF150557 & 2002 & F & HM026851 \\
\hline B & EF150555 & 2001 & F & HМ026850 \\
\hline B & EF150554 & 2001 & $\mathrm{~F}$ & HМ026849 \\
\hline B & EF150553 & 2000 & $\mathrm{~F}$ & HM026848 \\
\hline B & EF150552 & 2001 & $\mathrm{~F}$ & HM026847 \\
\hline B & EF150551 & 2000 & F & HМ026846 \\
\hline B & EF150550 & 2000 & F & HМ026845 \\
\hline B & EF150549 & 2000 & F & HМ026844 \\
\hline B & EF150548 & 2001 & $\mathrm{~F}$ & HМ026843 \\
\hline B & EF150547 & 2001 & F & HM026842 \\
\hline B & EF150546 & 2001 & $\mathrm{~F}$ & HМ026841 \\
\hline B & EF637057 & 2003 & $\mathrm{~F}$ & HM026840 \\
\hline B & EF637056 & 2003 & $\mathrm{~F}$ & HM026839 \\
\hline B & EF637054 & 2003 & $\mathrm{~F} 1$ & EF150631 \\
\hline B & EF637053 & 2003 & $\mathrm{~F} 1$ & EF150630 \\
\hline B & EF637051 & 2003 & $\mathrm{~F} 1$ & EF150629 \\
\hline B & EF637050 & 2003 & $\mathrm{~F} 1$ & AY214076 \\
\hline B & EF637049 & 2003 & $\mathrm{~F} 1$ & AY173958 \\
\hline B & EF637048 & 2003 & $\mathrm{~F} 1$ & AF005494 \\
\hline B & EF637047 & 2003 & $\mathrm{~F} 1$ & FJ480331 \\
\hline B & EF637046 & 2003 & $\mathrm{~F} 1$ & FJ771010 \\
\hline B & DQ358810 & 2002 & F1 & FJ771009 \\
\hline B & DQ358809 & 2002 & $\mathrm{~F} 1$ & FJ771008 \\
\hline B & DQ358808 & 2002 & $\mathrm{~F} 1$ & FJ771007 \\
\hline B & DQ358805 & 2002 & $\mathrm{~F} 1$ & FJ771006 \\
\hline B & FJ195091 & 2005 & $\mathrm{~F} 1$ & AB485657 \\
\hline B & FJ195090 & 2004 & $\mathrm{~F} 1$ & AB485656 \\
\hline B & FJ195089 & 2005 & $\mathrm{~F} 1$ & GQ864231 \\
\hline B & FJ195088 & 2005 & $\mathrm{~F} 1$ & GQ864228 \\
\hline B & FJ195086 & 2004 & $\mathrm{~F} 1$ & GQ864185 \\
\hline B & FJ480335 & 1996 & $\mathrm{~F} 1$ & GQ864183 \\
\hline B & FJ480334 & 1996 & $\mathrm{~F} 1$ & GQ864182 \\
\hline B & FJ480332 & 1996 & $\mathrm{~F} 1$ & HM439753 \\
\hline B & FJ480328 & 1996 & $\mathrm{~F} 1$ & HM439752 \\
\hline B & FJ480327 & 1996 & $\mathrm{~F} 1$ & HM439751 \\
\hline B & FJ480325 & 1996 & $\mathrm{~F} 1$ & HM439745 \\
\hline B & FJ480324 & 1996 & F1_BF & AY455785 \\
\hline
\end{tabular}




\begin{tabular}{|c|c|c|c|c|}
\hline B & AB485642 & 1990 & F1_BF1 & DQ358803 \\
\hline B & AB485641 & 1990 & F1_BF1 & DQ358800 \\
\hline B & GQ864237 & 2008 & F1_BF1 & DQ358799 \\
\hline B & GQ864236 & 2008 & F1_BF1 & AY455781 \\
\hline B & GQ864235 & 2008 & F1_BF1 & HМ026455 \\
\hline B & GQ864234 & 2008 & F1_BF1 & HM439756 \\
\hline B & GQ864233 & 2008 & F1_29BF & DQ085876 \\
\hline B & GQ864230 & 2008 & F1_29BF & AY455778 \\
\hline B & GQ864229 & 2008 & F1_46BF & DQ358802 \\
\hline B & GQ864226 & 2008 & $\mathrm{~F} 1 \_46 \mathrm{BF}$ & DQ358801 \\
\hline B & GQ864225 & 2008 & $\mathrm{~F} 1 \_46 \mathrm{BF}$ & AY455782 \\
\hline B & GQ864223 & 2008 & $\mathrm{~F} 1 \_46 \mathrm{BF}$ & HМ026460 \\
\hline B & GQ864222 & 2008 & $\mathrm{~F} 1 \_46 \mathrm{BF}$ & HМ026459 \\
\hline B & GQ864221 & 2008 & F1_46BF & HМ026458 \\
\hline B & GQ864220 & 2008 & F1_46BF & HМ026457 \\
\hline B & GQ864219 & 2008 & $\mathrm{~F} 1 \_46 \mathrm{BF}$ & HМ026456 \\
\hline B & GQ864217 & 2008 & $\mathrm{C}$ & EF150628 \\
\hline B & GQ864216 & 2008 & $\mathrm{C}$ & AY727525 \\
\hline B & GQ864215 & 2008 & $\mathrm{C}$ & AY727524 \\
\hline B & GQ864214 & 2008 & $\mathrm{C}$ & AY727523 \\
\hline B & GQ864213 & 2008 & $\mathrm{C}$ & AY727522 \\
\hline B & GQ864209 & 2008 & $\mathrm{C}$ & AF286228 \\
\hline B & GQ864208 & 2008 & $\mathrm{C}$ & U52953 \\
\hline B & GQ864207 & 2008 & $\mathrm{C}$ & HМ026837 \\
\hline B & GQ864206 & 2008 & $\mathrm{C}$ & HМ026836 \\
\hline B & GQ864205 & 2008 & $\mathrm{C}$ & HМ026835 \\
\hline B & GQ864204 & 2008 & $\mathrm{C}$ & HМ026834 \\
\hline B & GQ864203 & 2008 & $\mathrm{C}$ & НМ026833 \\
\hline B & GQ864202 & 2008 & $\mathrm{C}$ & HМ026832 \\
\hline B & GQ864201 & 2008 & $\mathrm{C}$ & HМ026829 \\
\hline B & GQ864199 & 2008 & $\mathrm{C}$ & HM026828 \\
\hline B & GQ864198 & 2008 & $\mathrm{C}$ & HМ026827 \\
\hline B & GQ864196 & 2008 & $\mathrm{C}$ & HМ026826 \\
\hline B & GQ864195 & 2008 & $\mathrm{C}$ & HM026825 \\
\hline B & GQ864194 & 2008 & $\mathrm{C}$ & HМ026824 \\
\hline B & GQ864193 & 2008 & $\mathrm{C}$ & НМ026823 \\
\hline B & GQ864192 & 2008 & $\mathrm{C}$ & HМ026822 \\
\hline B & GQ864191 & 2008 & $\mathrm{C}$ & HМ026821 \\
\hline B & GQ864190 & 2008 & $\mathrm{C}$ & HМ026820 \\
\hline B & GQ864189 & 2008 & $\mathrm{C}$ & HМ026819 \\
\hline B & GQ864188 & 2008 & $\mathrm{C}$ & НМ026818 \\
\hline B & GQ864187 & 2008 & $\mathrm{C}$ & HМ026817 \\
\hline B & GQ864186 & 2008 & $\mathrm{C}$ & HМ026816 \\
\hline B & GQ864184 & 2008 & $\mathrm{C}$ & HМ026815 \\
\hline B & GQ864181 & 2008 & $\mathrm{C}$ & НМ026814 \\
\hline B & GQ864179 & 2008 & $\mathrm{C}$ & НМ026813 \\
\hline
\end{tabular}




\begin{tabular}{llllll} 
B & GQ864178 & 2008 & C & HM026812 & 2001 \\
B & GQ864175 & 2008 & C & HM026811 & 2001 \\
B & GQ864174 & 2008 & C & HM026810 & 2001 \\
B & GQ864173 & 2008 & C & HM026809 & 2001 \\
B & GQ864172 & 2008 & C & HM026808 & 2001 \\
B & GQ864171 & 2008 & C & HM026807 & 2001 \\
B & GQ864170 & 2008 & C & HM026806 & 2001 \\
B & GQ864169 & 2008 & C & HM026805 & 2001 \\
B & GQ864167 & 2008 & C & HM026804 & 2001 \\
B & GQ864166 & 2008 & C & HM026803 & 2000 \\
B & GQ864165 & 2008 & C & HM026802 & 2000 \\
B & GQ864164 & 2008 & C & HM026801 & 2000 \\
B & GQ864163 & 2008 & C & HM026800 & 2000 \\
B & GQ864162 & 2008 & C & HM026799 & 2000 \\
B & HM026790 & 2002 & C & HM026798 & 2002 \\
B & HM026789 & 2002 & C & HM026797 & 2002 \\
B & HM026788 & 2000 & C & HM026796 & 2002 \\
B & HM026787 & 2000 & C & HM026795 & 2002 \\
B & HM026786 & 1999 & C & HM026794 & 2002 \\
B & HM026785 & 1998 & C & HM026793 & 2002 \\
B & HM026784 & 1998 & C & HM026792 & 2002 \\
B & HM026783 & 1998 & C & HM026791 & 2002 \\
B & HM026782 & 2003 & & & \\
\hline & & & & &
\end{tabular}


ANEXO B - ARTIGO 


\title{
Characterization of primary isolates of HIV-1 CRF28_BF, CRF29_BF and unique BF recombinants circulating in São Paulo, Brazil
}

\author{
Fernando Lucas Melo ${ }^{1}$, Leda Fátima Jamal ${ }^{2}$ and Paolo Marinho de Andrade Zanotto ${ }^{1} \dagger$ \\ ${ }^{1}$ Laboratory of Molecular Evolution and Bioinformatics, Department of Microbiology, \\ Biomedical Sciences Institute - ICBII, University of São Paulo, São Paulo, Brazil. \\ ${ }^{2}$ Training and Reference Center DST/AIDS, Control Diseases Center, Secretary of \\ Health of São Paulo State, São Paulo, Brazil.
}

Running Title:

Isolation and characterization of BF HIV

$\dagger$ Corresponding author:

Paolo Marinho de Andrade Zanotto

University of Sao Paulo - USP

Biomedical Sciences Institute - ICB II

Department of Microbiology

Av. Prof. Lineu Prestes, 1734

Sao Paulo - SP - Brazil - 05508-000

Phone: 551130918453

e-mail: pzanotto@usp.br 


\begin{abstract}
We report for the first time the genetic and biological characterization of ten HIV-1 primary isolates representing CRF28_BF and CRF29_BF together with additional unique BF recombinant forms (URFs) obtained by PBMC co-cultivation. Recombination is an important factor promoting the increase in the genetic diversity of in HIV-1. Notably more than twenty percent of HIV-1 sequenced worldwide are recombinants. In Brazil, several recombinant viruses were reported, and six circulating recombinant forms (CRFs) have already been identified (CRF28_BF, CRF29_BF, CRF31_BC, CRF39_BF, CRF40_BF, CRF46_BF). Some of these, such as CRF28_BF and CRF29_BF, were found to infect almost thirty percent of the patients in São Paulo State. The near full-length genomes of these ten primary isolates were amplified by nested PCR in three overlapping segments, purified and sequenced. Three samples were related to CRF28_BF, three to CRF29_BF and four were unique recombinant forms (URFs), according to their breakpoints profile determined with the jpHMM program. Additionally, the coreceptor usage of these isolate was investigated in vitro using GHOST assays, which revealed three dual-tropic (X4/R5) viruses, four lymphotropic (X4) viruses and three macrophage-tropic (R5) viruses. These results corroborate additional in silico analyses with the geno2pheno prediction algorithm, which predicted that the same seven isolates would use CXCR4 (X4 viruses) and the other three would use exclusively CCR5 receptor (R5 viruses). In sum, we report a well-characterized panel of viruses representing CRF28_BF, CRF29_BF and URFs from São Paulo State, Brazil.
\end{abstract}




\section{Introduction}

The intense investigation on HIV-1 genetic diversity has lead to the identification and description of different subtypes worldwide ${ }^{1-5}$. We currently believe that much of this variability results from the lack of proofreading activity of the viral reverse transcriptase ${ }^{6-7}$ along with a high rate of viral replication ${ }^{8-9}$. Additionally, recombination during reverse transcription is factor promoting HIV diversity and adaptive change ${ }^{10 \text {, reviewed in } 11}$, by allowing advantageous mutations arising on different genomes to undergo linkage in the same progeny recombinant genome more frequently than what would be expected under random mutation alone ${ }^{12-16}$. Moreover, intersubtype recombinants have been reported in increasing numbers in regions of the World where multiple subtypes do co-circulate to the extent that at least twenty percent of HIV-1 sequenced worldwide were found to be recombinant ${ }^{17-19}$. To date, forty nine circulating recombinant forms (CRFs) were identified (www.hiv.lanl.gov), and some of these have

been alarmingly successful in causing regional epidemics, e.g., CRF01_AE in Asia ${ }^{20}$ and CRF02_AG in Africa ${ }^{21-22}$. Likewise, several distinct BF recombinant viruses have been described in South America ${ }^{23}$. Notably, full genome sequencing of these viruses revealed at least nine recombinant lineages that fulfilled the criteria to be recognized as CRFs (CRF12_BF, CRF17_BF, CRF28_BF, CRF29_BF, CRF38_BF, CRF39_BF, CRF40_BF, CRF44_BF and CRF46_BF) (www.hiv.lanl.gov).

Such great diversity of successful CRFs BF could entail an adaptive advantage for these recombinants, since we can assume that, to be efficiently transmitted, the emerging recombinant must first overgrow its parental strain within the coinfected individual. Actually, two independent lines of evidence suggest that BF recombinants may exhibit different biological behaviors. First, a high rate of population growth was observed for both CRF12_BF and CRF38_BF in Argentina and Uruguay ${ }^{24-25}$. Second, 
it was demonstrated that the $\mathrm{BF}$ recombinant LTR/Tat complex has higher transcriptional activity compared to subtype $\mathrm{B}$ complex $^{26}$ and, that $\mathrm{BF} \mathrm{Vpu}$-harboring variants have increased fitness compared to subtype $\mathrm{B}$ in vitro ${ }^{27}$. Nevertheless, it remains to be investigated to what extent these results could be generalized to other BF recombinants spreading in South America.

Therefore, it is paramount to try obtaining primary isolates for the most prevalent BF mosaics, like CRF28_BF and CRF29_BF, which were already found to infect almost thirty percent of HIV-1carriers in some places in São Paulo State ${ }^{28-29}$. Herein, we report the genetic and biological characterization of $10 \mathrm{HIV}-1$ primary isolates representing CRF28_BF, CRF29_BF and unique BF recombinant forms (URFs), in order to contribute to the construction of a panel of well-characterized BF recombinant viruses.

\section{Material and Methods}

Ethics Statements, Clinical samples and Virus isolation. The study was submitted and approved by the Ethics Committee on Human Research of the University of São Paulo and informed consent terms were signed by all patients. Ten patients harboring BF recombinant viruses were selected from the Viral Genetic Diversity Network (VGDN) program ${ }^{30}$, based on their available clinical and epidemiological information. HIV-1 isolation was performed by co-culture of freshly harvested peripheral blood mononuclear cells (PBMC) and uninfected PHA-stimulated PBMCs according to ACTG Virology Manual for HIV Laboratories guidelines ${ }^{31}$. Viral growth was monitored by p24 antigen production using the Vironostika ${ }^{\circledR}$ HIV-1 antigen Microelisa 
kit (bioMérieux, Netherlands). Positive cultures were further expanded in PHAstimulated PBMCs to produce viral stocks.

DNA extraction, PCR and near full-length genome sequencing. DNA was extracted from infected PBMCs using QIAamp DNA Blood kit (Qiagen, Germany), according to manufacturer's instructions, and stored at $-80^{\circ} \mathrm{C}$ until use. Three overlapping regions of the viral genome were amplified using nested PCR according to ${ }^{32}$. PCR products were purified with QIAquick PCR Purification Kit (Qiagen, Germany). Sequencing reactions were performed using BigDyeTerminator version 3.0 cycle sequencing (ABI Prism; PE Applied Biosystems, Foster City, CA), and the products were analyzed on ABI 3100 automated DNA sequencers (PE Applied Biosystem). Primers used for sequencing reactions are described in supplementary Table S1. Sequence data were edited and assembled with CodonCode Aligner software (Gene Codes Corporation).

Recombination analysis. The available genome sequences were analyzed with the jumping profile hidden Markov model (jpHMM) $\operatorname{program}^{33-34}$, which uses detailed information on polymorphism of the parental populations rather than using individual parental strains and provides detailed information on the reliability of the predicted recombination breakpoints ${ }^{35}$.

Genotypic and Phenotypic analysis of coreceptor usage. Despite the availability of different methods to predict coreceptor usage, the geno2pheno algorithm was found to be the more sensitive do detect CXCR4 variants ${ }^{36}$. The V3 sequences were analyzed with the geno2pheno ${ }_{[\text {coreceptor] }}$ tropism prediction algorithm using the clonal setting and a $20 \%$ false-positive rates (FPR) as the cutoff. This FPR value was chosen since it 
minimizes the number of falsely predicted R5 tropic viruses ${ }^{36}$. The phenotypic evaluation of coreceptor usage was done on GHOST(3) indicator cell lines expressing CD4 and either CCR5 or CXCR4 (NIH AIDS Reagent Program) ${ }^{37}$. The GHOST cells were grown in DMEM (Invitrogen) supplemented with 10\% FCS, penicillin (50 U/mL), streptomycin $(50 \mathrm{U} / \mathrm{mL})$ and L-glutamine $(2 \mathrm{mM})$, and selected with G418 (500 $\mu \mathrm{g} / \mathrm{mL})$, hygromycin $(100 \mu \mathrm{g} / \mathrm{mL})$ and puromycin $(1 \mu \mathrm{g} / \mathrm{mL})$. Infection was carried out as described $\mathrm{in}^{37}$. Briefly, cells were seeded in 24-well plates one day before infection. The following day, the medium was replaced with $200 \mu \mathrm{l}$ of fresh medium containing polybrene $(2 \mu \mathrm{g} / \mathrm{mL})$ and $300 \mu \mathrm{l}$ of virus stock. Cultures were incubated overnight, washed with PBS and further incubated with fresh medium. Infected cells expressing GFP were detected 2 or 3 days after infection by fluorescence microscopic observation. CXCR4 usage was confirmed using the antagonist AMD3100 ${ }^{38-40}$, added to the cells prior to infection at a concentration of $1 \mu \mathrm{M}$. JM-2987 (hydrobromide salt of AMD 3100) was obtained from the NIH AIDS research and Reference Reagent Program.

\section{Results}

\section{Clinical features and viral isolation}

HIV-1 primary isolates were obtained from each sampled patient, as confirmed by the p24 antigen capture assay. Clinical information is summarized in Table 1. Most patients were men (7/10) and the predominant risk behavior for HIV infection was unprotected heterosexual intercourse. Six isolates were obtained from AIDS patients with CD4 count ranging from 10 to 632 cells/ml and viral load ranging from undetectable to 45,600 copies $/ \mathrm{ml}$. The remaining four isolates were obtained from asymptomatic patients with CD4 count ranging from 169 to 693 cells/ml and viral load 
ranging from 450 to 150,247 to copies/ml (Table 1). The date of first HIV-1 positive test ranged from 1985 to 2003 (Table 1).

\section{Genomic characterization and recombination patterns}

The near full-length genomes of all primary isolates were successfully amplified and sequenced. The sequences were on average $8.8 \mathrm{~kb}$ in length, with intact open reading frames. To allow the amplification of all open reading frames of each provirus, we had to avoid pairs of primers that would amplify only a single LTR. Therefore, 140 base pairs were not amplified by our strategy. It is worth mentioning that any other group does not report this stretch of proviral sequence as well, possibly for the same reason. Additionally, to check the possibility of contamination among samples, the sequenced genomes were compared using the Blast2Seq tool of $\mathrm{NCBI}^{41}$, which revealed that no cross-contamination appeared to have occurred. Three samples were classified as CRF28_BF (0614SV, 0679SV and 0744SV) and three as CRF29_BF (0063SP, 0264RI and 0647SV), according to the breakpoints profile, summarized in Fig. 1 and Table S1. The estimated breakpoints for these isolates were slightly different from those originally described for CRF28_BF (B: 832-1322, F1: 1323-2571, B: 2572-9432) and CRF29_BF (B: 823-1322, F1: 1323-2571, B: 2572-3682, F1: 3683-5462, B: 5463-9432) ${ }^{42}$. The remaining four isolates (0008SP, 0341RI, 0632SV and 0736SV) were classified as URFs (Fig. 1). Interestingly, two of them (0008 and 0736) shared some breakpoints with CRF28_BF or CRF29_BF. The recombination pattern of isolate 0008SP was quite complex, sharing breakpoints with CRF29_BF at position 3748 \pm 45 . The isolate $0736 \mathrm{SV}$ also had a breakpoint located at position $1300 \pm 78$, resembling the profile of CRF28_BF, but had a second one at $2317 \pm 34$, which is $200 \mathrm{bp}$ away from the

predicted $^{23}$, which indicates that this recombinant virus is possibly an example of a 
further generation recombinant. It was noteworthy that the isolate $0632 \mathrm{SV}$ had the same mosaic structure and breakpoints $(6583 \pm 20-7659 \pm 30$, Fig. S2) of a previously published sequence (DQ358806/02BR005) sampled in São Paulo ${ }^{43}$.

\section{V3 loop characteristics and coreceptor usage}

As shown in Fig. 1, the 0632SV had a subtype F1 V3 sequence, whereas the remaining sequences had a subtype B V3 loop. The predicted amino acid alignment showed a great diversity of tetrameric amino acid motifs at the tip of the V3 loop (Table 2). Overall, we found seven different motifs, with GWGR (3/10) and GPGR (2/10) being the most common. The GWGR motif was present in two out of three isolates of CRF28_BF and in one isolate of CRF29_BF. This contrasts with previous findings showing that GWGR motif was not commonly present in CRF_BF isolates ${ }^{44}$. Furthermore, the length of the V3 loop was variable among our isolates (ranging from 34 to $37 \mathrm{aa}$ ). In particular, the isolate $0008 \mathrm{SP}$ had a deletion at position 11 , which is a

well known determinant of cell tropism ${ }^{45}$. To exclude the possibility of defective provirus amplification or sequencing artifact, both PCR and sequencing steps were repeated, confirming this was indeed a bona fide deletion (Fig. S1).

We then investigated the coreceptor usage of these isolates, using both genotyping and phenotyping methods. Initially, we did a preliminary in silico analysis using the Geno2pheno algorithm. As shown in Table 2, seven isolates were predicted to use CXCR4 as entry coreceptor, including the aforementioned isolate 0008SP, while the remaining three were predicted to exclusively use CCR5. We then checked the isolates tropism in vitro using GHOST(3) cell assay (Table 2). All three isolates predicted as CCR5-tropic replicated in GHOST(3)-CCR5 cells but did replicate in cells expressing CXCR4, conforming that they were exclusively macrophage tropic (i.e. used CCR5 as 
entry coreceptor). The remaining seven isolates that were predicted by gene2pheno to use CXCR4, replicated in GHOST(3)-CXCR4 cells. Nevertheless, three of them (0341SV, 0614SV, 0647SV) also replicated in GHOST(3)-CCR5 cells and were defined as dual tropic viruses (Table 2). Since GHOST(3) cell lines express low levels of endogenous CXCR4, these results were further confirmed by blocking the CXCR4 coreceptor with the antagonist AMD3100. As expected, only those viruses previously classified as CCR5-tropic or dual tropic were able to infect GHOST-CCR5. Despite the limited number of isolates described here, there was no relationship between clinical status and the presence of CXCR4-tropic variants.

\section{Discussion}

We performed for the first time the isolation and characterization of CRF28_BF and CRF29_BF viruses, which are highly prevalent among our HIV-1 infected population. It is noteworthy that clinical data showed that one of the sampled patients, harboring a CRF29_BF (0063SP) virus, was first diagnosed in 1985. This suggests that this CRF has been cryptically circulating at least 14 years before its description, in patients sampled between 1999 and $2002^{42}$, even before the first description of a HIV-1 recombinant in Brazil, in $1992^{46}$. Alternatively, this patient could have been infected with another subtype at time of first HIV-1 positive diagnostic and later re-infected by the recombinant form isolated here. However, sequencing several distinct PCR products obtained after limiting dilution (which effect mimics cloning) did not reveal any evidence of dual infection in PBMCs from this patient (data not shown). Also, the observed date of 1985 agrees with an independent estimate for the origin of Brazilian 
BF recombinants, ranging from 1984 to $1991^{47}$. Taken together, these results indicated that this CRF might have well originated before 1985.

We have also identified two URFs sharing breakpoints with CRF28/29, which may constitute evidence for so-called second generation of $\mathrm{BF}$ recombinants (i.e., recombinant progeny involving at least one distinct parental CRFs). Alternatively, these URFs may sport convergent breakpoints as a consequence of shared recombination hotspots. Nevertheless, the existence of these URFs may constitute important evidence that superinfection may be a common event, which agrees with reports on high frequency of superinfection among HIV carriers ${ }^{48}$. Indeed, the large number of unique BF recombinants found in South America ${ }^{23}$ strongly supports the notion that different genotypes may be circulating and superinfecting hosts. Together these findings stress a pivotal role of co-circulation and superinfection in the emergence of new recombinant forms. This could be the case of isolate $0632 \mathrm{SV}$, which may be a new CRF_BF circulating in São Paulo State, since it shares all the recombination breakpoints with a previously published sequence from a nearby location ${ }^{49}$.

Most in silico analyses characterizing HIV recombinants have been done with bootscanning methods. Even though this methodology is efficient in recombination detection, it is largely dependent on the choice of parental strains, which affect the accuracy of the breakpoint prediction. In our case, the use of jpHMM provided a better resolution of break points, which is crucial for the proper identification of CRFs (supplementary Table S1). Most likely, this was a consequence of an improved accuracy in breakpoint prediction available in more recent versions of the jpHMM algorithm and, the increasing availability of near full-length genome sequences used as references $^{35}$. Recently, an extensive reassessment of public database HIV sequences 
using jpHMM also described such discordant breakpoints, and reassigned two reference sequences, CRF28_BF (DQ085874) and CRF29_BF (AY771590) ${ }^{23}$, as URFs.

The V3 loop in the gp120 protein is considered the major viral determinant for cellular tropism ${ }^{45}$ and, also a preferential target of humoral ${ }^{50}$ and cellular ${ }^{51}$ responses. Accordingly, we observed among our isolates considerable variability at the tetrapeptide motif at the V3 loop. Furthermore, we did not find any relationship between tetrapeptide motif and coreceptor usage, in line with a previous work that also described GWGR isolates as being capable to use CXCR4 as entry coreceptor ${ }^{52}$. We would argue that our finding was relevant, since it provided empirical evidence against the belief that variants carrying the GWGR tetramer would use exclusively the CCR5 coreceptor $^{53}$. Crucially, these findings provide further biological evidence that this motif (GWGR) alone does not determine the coreceptor usage ${ }^{54}$. Moreover, CXCR4-tropic viruses were more common than CCR5-tropic (7 and 3, respectively), regardless of the recombination profile and patient clinical status. Furthermore, despite our limited sample size but because both in vitro and in silico procedures converged on CXCR4 usage determination, it is worthwhile asking if the Geno2pheno algorithm may indeed increase accuracy in coreceptor usage prediction. This information is of relevance for patient treatment with CCR5 antagonists, which is a drug class recently approved for extensive use in Brazil.

We report a unique and well-characterized panel of viruses representing CRF28_BF, CRF29_BF and URFs BF. We also present evidence that at least CRF29_BF may have been circulating around 1985, at the beginning of the AIDS epidemics in Brazil, which dates at least 20 years before its detection in samples from $2002^{42}$. Moreover, we found a high number of URFs (4:10) compared with that of CRFs (6:10), which highlights the fact that superinfection may be frequent enough to 
merit in-depth studies of its intra-host and epidemiological relevant factors. In sum, we believe that the isolates we present could be useful to advance our knowledge of well established BF recombinants, which are experiencing growing epidemiological importance. It is quite relevant to consider that $\mathrm{BF}$ recombinant viruses constitute the majority (11 out of 49) of the CRFs described to date (Los Alamos). Moreover, BF viruses originated on Brazil, may have far a reaching effect on the HIV pandemics, since they have already been isolated in Asia and Europe ${ }^{55}$. 


\section{Acknowledgments}

This research was made possible by the Viral Genetic Diversity (VGDN) program funded by the Fundação de Amparo à Pesquisa do Estado de São Paulo (FAPESP) (www.fapesp.br) project number 00/04205-6. FLM holds a FAPESP doctorate scholarship (process number 07/01554-9). PMAZ holds a CNPq PQ research scholarship. The following reagents were obtained through the NIH AIDS Research and Reference Reagent Program, Division of AIDS, NIAID, NIH: bicyclam JM-2987 (hydrobromide salt of AMD-3100), GHOST cells from Dr. Vineet N. Kewal Ramani and Dr. Dan R. Littman. We are also grateful to those patients who kindly agreed to collaborate in this study. 
Sequence Data

Sequences are deposited in GenBank under accession numbers: 


\section{References}

1. Taylor BS, Sobieszczyk ME, McCutchan FE, Hammer SM. The challenge of HIV-1 subtype diversity. N Engl J Med. Apr 10 2008;358(15):1590-1602.

2. Papathanasopoulos MA, Hunt GM, Tiemessen CT. Evolution and diversity of HIV-1 in Africa--a review. Virus Genes. 2003;26(2):151-163.

3. McCutchan FE. Understanding the genetic diversity of HIV-1. AIDS. 2000;14 Suppl 3:S31-44.

4. Cock KM, Weiss HA. The global epidemiology of HIV/AIDS. Trop Med Int Health. Jul 2000;5(7):A3-9.

5. Hamers FF, Downs AM, Infuso A, Brunet JB. Diversity of the HIV/AIDS epidemic in Europe. AIDS. 1998;12 Suppl A:S63-70.

6. Preston BD, Poiesz BJ, Loeb LA. Fidelity of HIV-1 reverse transcriptase. Science. Nov 25 1988;242(4882):1168-1171.

7. Roberts JD, Bebenek K, Kunkel TA. The accuracy of reverse transcriptase from HIV-1. Science. Nov 25 1988;242(4882):1171-1173.

8. Perelson AS, Neumann AU, Markowitz M, Leonard JM, Ho DD. HIV-1 dynamics in vivo: virion clearance rate, infected cell life-span, and viral generation time. Science. Mar 15 1996;271(5255):1582-1586.

9. Ho DD, Neumann AU, Perelson AS, Chen W, Leonard JM, Markowitz M. Rapid turnover of plasma virions and CD4 lymphocytes in HIV-1 infection. Nature. Jan 12 1995;373(6510):123-126.

10. Neher RA, Leitner T. Recombination rate and selection strength in HIV intrapatient evolution. PLoS Comput Biol. Jan 2010;6(1):e1000660.

11. Ramirez BC, Simon-Loriere E, Galetto R, Negroni M. Implications of recombination for HIV diversity. Virus Res. Jun 2008;134(1-2):64-73.

12. Arora P, Dixit NM. Timing the emergence of resistance to anti-HIV drugs with large genetic barriers. PLoS Comput Biol. Mar 2009;5(3):e1000305.

13. Streeck H, Li B, Poon AF, et al. Immune-driven recombination and loss of control after HIV superinfection. J Exp Med. Aug 4 2008;205(8):1789-1796.

14. Nora T, Charpentier C, Tenaillon O, Hoede C, Clavel F, Hance AJ. Contribution of recombination to the evolution of human immunodeficiency viruses expressing resistance to antiretroviral treatment. J Virol. Jul 2007;81(14):76207628.

15. Charpentier $\mathrm{C}$, Nora $\mathrm{T}$, Tenaillon $\mathrm{O}$, Clavel $\mathrm{F}$, Hance AJ. Extensive recombination among human immunodeficiency virus type 1 quasispecies makes an important contribution to viral diversity in individual patients. Journal of Virology. Mar 2006;80(5):2472-2482.

16. Moutouh L, Corbeil J, Richman DD. Recombination leads to the rapid emergence of HIV-1 dually resistant mutants under selective drug pressure. Proc Natl Acad Sci U S A. Jun 11 1996;93(12):6106-6111.

17. Osmanov S, Pattou C, Walker N, Schwardlander B, Esparza J. Estimated global distribution and regional spread of HIV-1 genetic subtypes in the year 2000. $J$ Acquir Immune Defic Syndr. Feb 1 2002;29(2):184-190.

18. Hemelaar J, Gouws E, Ghys P, Osmanov S, Characterisation WUNfHIa. Global trends in molecular epidemiology of HIV-1 during 2000-2007. In: IAS, ed. XVIII International AIDS Conference. Vol Abstract no. THAA0201. Vienna Austria; 2010. 
19. Hemelaar J, Gouws E, Ghys PD, Osmanov S. Global and regional distribution of HIV-1 genetic subtypes and recombinants in 2004. AIDS. Oct 24 2006;20(16):W13-W23.

20. Gao F, Robertson DL, Morrison SG, et al. The heterosexual human immunodeficiency virus type 1 epidemic in Thailand is caused by an intersubtype (A/E) recombinant of African origin. Journal of Virology. Oct 1996;70(10):7013-7029.

21. Montavon $\mathrm{C}$, Toure-Kane $\mathrm{C}$, Liegeois $\mathrm{F}$, et al. Most env and gag subtype A HIV-1 viruses circulating in West and West Central Africa are similar to the prototype AG recombinant virus IBNG. Journal of Acquired Immune Deficiency Syndromes. Apr 15 2000;23(5):363-374.

22. Andersson S, Norrgren H, Dias F, Biberfeld G, Albert J. Molecular characterization of human immunodeficiency virus (HIV)-1 and -2 in individuals from guinea-bissau with single or dual infections: predominance of a distinct HIV-1 subtype A/G recombinant in West Africa. Virology. Sep 30 1999;262(2):312-320.

23. Zhang M, Foley B, Schultz AK, et al. The role of recombination in the emergence of a complex and dynamic HIV epidemic. Retrovirology. 2010;7:25.

24. Bello G, Aulicino PC, Ruchansky D, et al. Phylodynamics of HIV-1 circulating recombinant forms 12_BF and 38_BF in Argentina and Uruguay. Retrovirology. 2010;7:22.

25. Aulicino PC, Holmes EC, Rocco C, Mangano A, Sen L. Extremely rapid spread of human immunodeficiency virus type $1 \mathrm{BF}$ recombinants in Argentina. $J$ Virol. Jan 2007;81(1):427-429.

26. Turk G, Carobene M, Monczor A, Rubio AE, Gomez-Carrillo M, Salomon H. Higher transactivation activity associated with LTR and Tat elements from HIV1 BF intersubtype recombinant variants. Retrovirology. 2006;3:14.

27. De Candia C, Espada C, Duette G, et al. Viral replication is enhanced by an HIV-1 intersubtype recombination-derived Vpu protein. Virol J. Oct 4 2010;7(1):259.

28. de Souza AC, de Oliveira CM, Rodrigues CL, Silva SA, Levi JE. Short communication: Molecular characterization of HIV type $1 \mathrm{BF}$ pol recombinants from Sao Paulo, Brazil. AIDS Res Hum Retroviruses. Dec 2008;24(12):15211525.

29. Teixeira D, Munerato $\mathrm{P}$, Komninakis SC, et al. The detection of in vivo and in vitro HIV type $1 \mathrm{~B} / \mathrm{F}$ profiles in Brazil using a real-time PCR assay for five HIV type 1 genomic regions. AIDS Res Hum Retroviruses. Sep 2010;26(9):981-990.

30. Pardini MI, Jamal LF, Durigon EL, et al. Boosting virology in Brazil. Plos Biology. Mar 2008;6(3):428-429.

31. Hollinger FB, Bremer JW, Myers LE, Gold JW, McQuay L. Standardization of sensitive human immunodeficiency virus coculture procedures and establishment of a multicenter quality assurance program for the AIDS Clinical Trials Group. The NIH/NIAID/DAIDS/ACTG Virology Laboratories. J Clin Microbiol. Jul 1992;30(7):1787-1794.

32. Nadai Y, Eyzaguirre LM, Constantine NT, et al. Protocol for Nearly Full-Length Sequencing of HIV-1 RNA from Plasma. Plos One. Jan 9 2008;3(1):-.

33. Zhang M, Schultz AK, Calef C, et al. jpHMM at GOBICS: a web server to detect genomic recombinations in HIV-1. Nucleic Acids Research. Jul 1 2006;34:W463-W465. 
34. Schultz AK, Zhang M, Leitner $\mathrm{T}$, et al. A jumping profile Hidden Markov Model and applications to recombination sites in HIV and HCV genomes. Bmc Bioinformatics. May 22 2006; 7:-.

35. Schultz AK, Zhang M, Bulla I, et al. jpHMM: Improving the reliability of recombination prediction in HIV-1. Nucleic Acids Research. Jul 1 2009;37:W647-W651.

36. Sanchez V, Masia M, Robledano C, Padilla S, Ramos JM, Gutierrez F. Performance of genotypic algorithms for predicting HIV-1 tropism measured against the enhanced-sensitivity Trofile coreceptor tropism assay. J Clin Microbiol. Nov 2010;48(11):4135-4139.

37. Morner A, Bjorndal A, Albert J, et al. Primary human immunodeficiency virus type 2 (HIV-2) isolates, like HIV-1 isolates, frequently use CCR5 but show promiscuity in coreceptor usage. Journal of Virology. Mar 1999;73(3):23432349.

38. Hendrix CW, Flexner C, MacFarland RT, et al. Pharmacokinetics and safety of AMD-3100, a novel antagonist of the CXCR-4 chemokine receptor, in human volunteers. Antimicrob Agents Chemother. Jun 2000;44(6):1667-1673.

39. De Clercq E, Yamamoto N, Pauwels R, et al. Highly potent and selective inhibition of human immunodeficiency virus by the bicyclam derivative JM3100. Antimicrob Agents Chemother. Apr 1994;38(4):668-674.

40. Bridger GJ, Skerlj RT, Thornton D, et al. Synthesis and structure-activity relationships of phenylenebis(methylene)-linked bis-tetraazamacrocycles that inhibit HIV replication. Effects of macrocyclic ring size and substituents on the aromatic linker. J Med Chem. Jan 20 1995;38(2):366-378.

41. Altschul SF, Madden TL, Schaffer AA, et al. Gapped BLAST and PSI-BLAST: a new generation of protein database search programs. Nucleic Acids Res. Sep 1 1997;25(17):3389-3402.

42. De Sa Filho DJ, Sucupira MC, Caseiro MM, Sabino EC, Diaz RS, Janini LM. Identification of two HIV type 1 circulating recombinant forms in Brazil. AIDS Res Hum Retroviruses. Jan 2006;22(1):1-13.

43. Sanabani S, Kleine Neto W, Kalmar EM, Diaz RS, Janini LM, Sabino EC. Analysis of the near full length genomes of HIV-1 subtypes B, F and BF recombinant from a cohort of 14 patients in Sao Paulo, Brazil. Infect Genet Evol. Sep 2006;6(5):368-377.

44. Leal E, Villanova FE. Diversity of HIV-1 subtype B: implications to the origin of BF recombinants. PLoS One. 2010;5(7):e11833.

45. Fouchier RA, Groenink M, Kootstra NA, et al. Phenotype-associated sequence variation in the third variable domain of the human immunodeficiency virus type 1 gp120 molecule. J Virol. May 1992;66(5):3183-3187.

46. Sabino EC, Shpaer EG, Morgado MG, et al. Identification of human immunodeficiency virus type 1 envelope genes recombinant between subtypes B and $\mathrm{F}$ in two epidemiologically linked individuals from Brazil. $J$ Virol. Oct 1994;68(10):6340-6346.

47. Leal, Eacute, lcio, Martins LO, Janini LM, Diaz RS. Evolutionary Dynamics of HIV-1 BF and CB Recombinants and Its Parental Counterparts in South America. Retrovirology: Research and Treatment. 2008;2008(RRT-1-Leal-etal): 1 .

48. Piantadosi A, Chohan B, Chohan V, McClelland RS, Overbaugh J. Chronic HIV-1 infection frequently fails to protect against superinfection. PLoS Pathog. Nov 2007;3(11):e177. 
49. Sanabani S, Pastena E, Neto W, Martinez V, Sabino E. Characterization and frequency of a newly identified HIV-1 BF1 intersubtype circulating recombinant form in Sao Paulo, Brazil. Virol J. 2010;7:74.

50. Javaherian K, Langlois AJ, LaRosa GJ, et al. Broadly neutralizing antibodies elicited by the hypervariable neutralizing determinant of HIV-1. Science. Dec 14 1990;250(4987):1590-1593.

51. Kmieciak D, Wasik TJ, Teppler H, et al. The effect of deletion of the V3 loop of gp120 on cytotoxic T cell responses and HIV gp120-mediated pathogenesis. $J$ Immunol. Jun 1 1998;160(11):5676-5683.

52. Ferraro GA, Mello MAG, Sutmoller F, et al. Biological characterization and chemokine receptor usage of HIV type 1 isolates prevalent in Brazil. Aids Research and Human Retroviruses. Sep 2001;17(13):1241-1247.

53. Leal E, Silva WP, Sucupira MC, Janini LM, Diaz RS. Molecular and structural characterization of HIV-1 subtype B Brazilian isolates with GWGR tetramer at the tip of the V3-loop. Virology. Nov 25 2008;381(2):222-229.

54. Tomasini-Grotto R-M, Montes B, Triglia D, et al. Variability of the conserved V3 loop tip motif in HIV-1 subtype B isolates collected from Brazilian and French patients. Brazilian Journal of Microbiology. 2010;41:720-728.

55. Bruselles A, Rozera G, Bartolini B, et al. Use of massive parallel pyrosequencing for near full-length characterization of a unique HIV Type $1 \mathrm{BF}$ recombinant associated with a fatal primary infection. AIDS Res Hum Retroviruses. Sep 2009;25(9):937-942.

Address reprint requests to:

Paolo Marinho De Andrade Zanotto

University of Sao Paulo - USP

Biomedical Sciences Institute - ICB II

Department of Microbiology

Av. Prof. Lineu Prestes, 1734

Sao Paulo - SP - Brazil - 05508-000 


\section{Figure Legend}

Fig. 1. Near full-length genome map of the $10 \mathrm{BF}$ recombinant primary isolates. Breakpoints and subtype composition of isolates revealed mosaic structures related to CRF28_BF (3), CRF29_BF (3) and URFs (4). Recombination breakpoints were determined with the jpHMM algorithm available online at the GOBICS server (http://jphmm.gobics.de/jphmm.html). Fragments related to subtype B are shown in blue and to subtype F1 in green. 
Figure 1

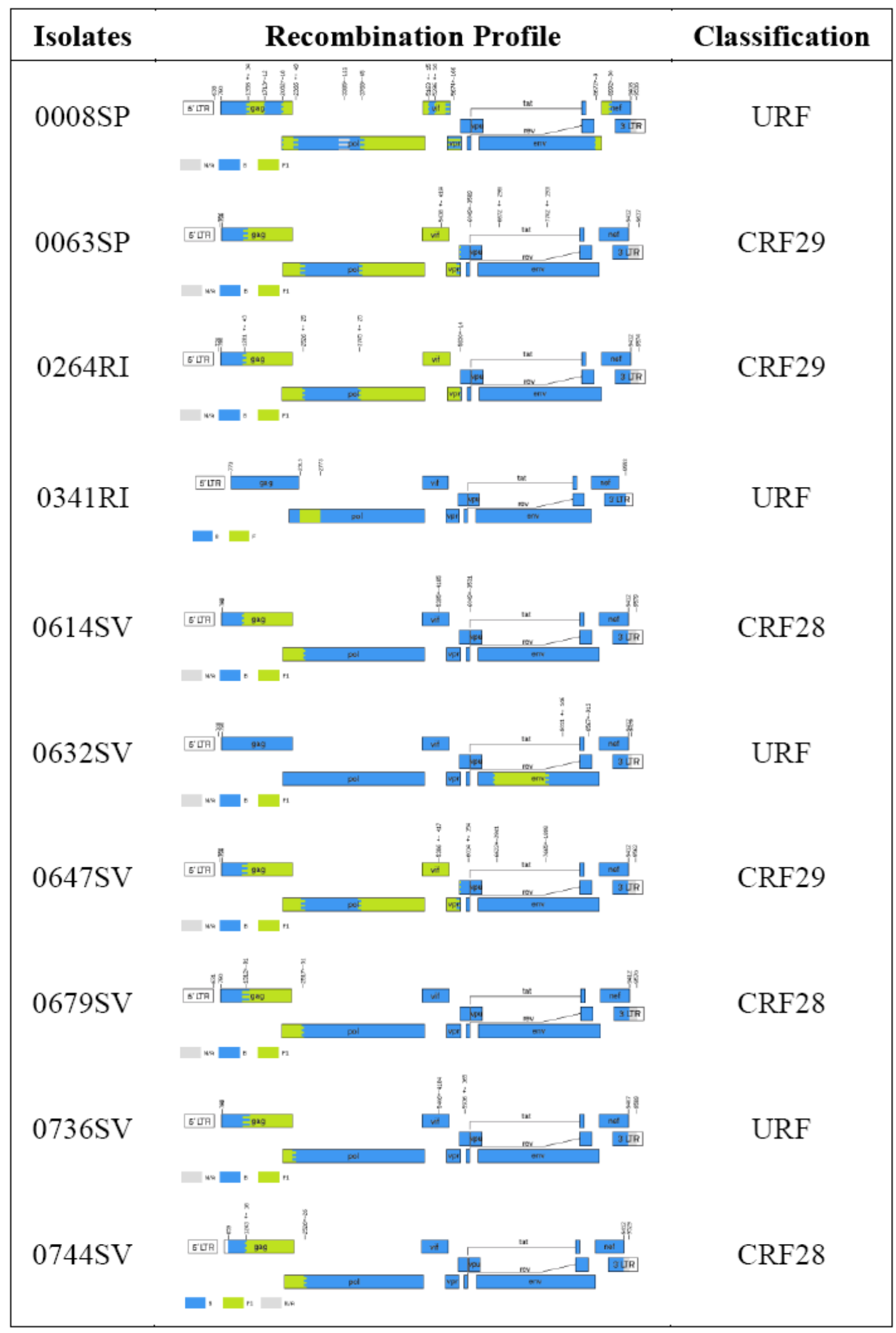


Table 1. Clinical data of sampled patients.

\begin{tabular}{|c|c|c|c|c|c|c|c|}
\hline $\begin{array}{c}\text { Patient } \\
\text { ID }\end{array}$ & Sex & $\begin{array}{c}\text { Risk } \\
\text { Behavior }^{1}\end{array}$ & $\begin{array}{c}\text { Year of } \\
\text { Diagnosis }^{2}\end{array}$ & AIDS & $\begin{array}{c}\text { CD4 } \\
\text { (cells/ml) }\end{array}$ & $\begin{array}{l}\text { Viral load } \\
\text { (copies/ml) }\end{array}$ & $\begin{array}{c}\text { Antiretroviral } \\
\text { treatment }\end{array}$ \\
\hline 0008SP & Female & HT & 1996 & - & 595 & 450 & NRTI+NRTI \\
\hline 0063SP & Male & HT,IDU,BT & 1985 & + & 10 & 45,600 & NRTI+NRTI+PI \\
\hline 0264RI & Male & MSM,IDU & 1995 & + & 632 & 22,000 & None \\
\hline 0341RI & Female & HT/BT & 1995 & - & 554 & 54,500 & NRTI+NRTI \\
\hline 0614SV & Male & HT & 1998 & + & 499 & $<50$ & NRTI+NRTI+PI \\
\hline 0632SV & Male & HT & 2003 & - & 169 & 150,347 & NRTI+NRTI+PI \\
\hline 0647SV & Male & HT & 1995 & - & na & 12,284 & None \\
\hline 0679SV & Male & HT & 1995 & + & 202 & 5,665 & NRTI+NRTI+PI \\
\hline 0736SV & Male & MSM,IDU & 1992 & - & 693 & 890 & NRTI+NRTI \\
\hline 0744SV & Female & HT,BT & 2003 & - & na & 22,395 & NRTI+NRTI \\
\hline
\end{tabular}


Table 2. Genotypic and phenotypic characterization of co-receptor usage of primary isolates of HIV-1 BF recombinants.

\begin{tabular}{ccccccc}
\hline Sample & Genome & env & V3 & GHOST & AMD \\
& subtype & subtype & tetramer & & Assay & sensitivity \\
\hline 0008SP & URF & B & GPGR & X4 & X4 & yes \\
0063SP & CRF29 & B & GSGR & X4 & X4 & yes \\
0264RI & CRF29 & B & GRGR & X4 & X4 & yes \\
0341RI & URF & B & GLGR & X4 & R5/X4 & no \\
0614SV & CRF28 & B & GPGR & X4 & R5/X4 & no \\
0632SV & URF & F & GPGK & R5 & R5 & no \\
0647SV & CRF29 & B & GWGR & X4 & R5/X4 & no \\
0679SV & CRF28 & B & GWGR & R5 & R5 & no \\
0736SV & URF & B & GVGR & X4 & X4 & yes \\
0744SV & CRF28 & B & GWGR & R5 & R5 & no \\
\hline
\end{tabular}




\section{Supplementary Figure Legends}

Fig. S1. Electropherogram, of a sequencing reaction from the V3 region of isolate 0008SP. The black arrow shows the observed deletion at position 11 .

Fig. S2. Comparison between the recombination profiles of isolate 0632SV_URF and a previously published sequence from a nearby location (BF1.BR.2002.02BR005 Accession number: DQ358806). These sequences have identical breakpoints in the env region and may represent a new CRF_BF circulating in São Paulo State. 
Figure S1

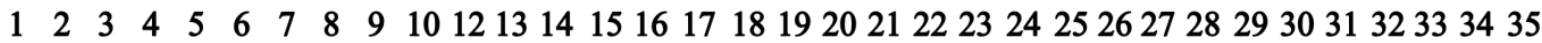

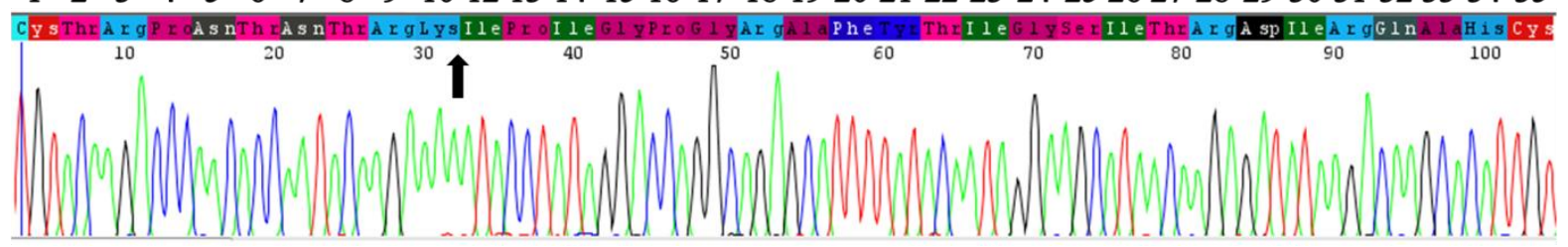


Figure S2

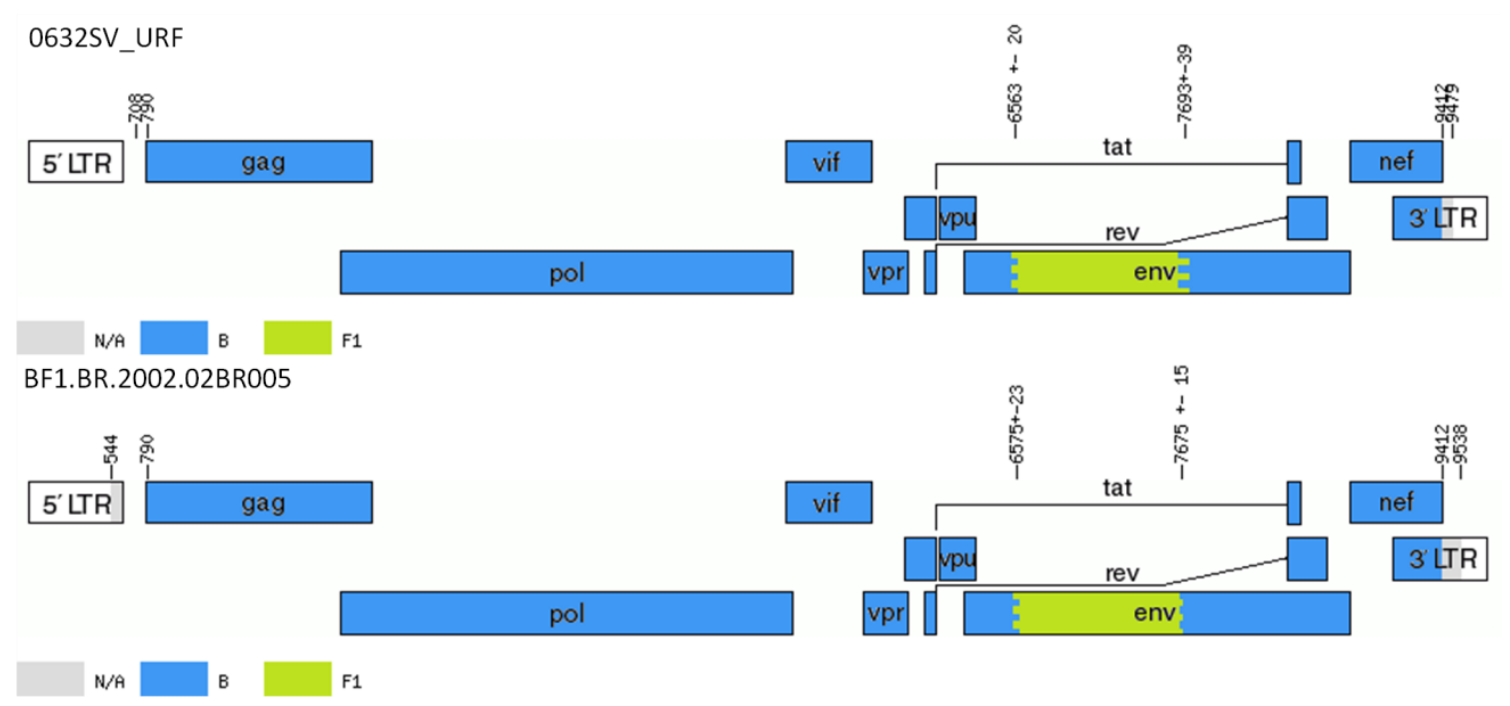


TABLE S1. Breakpoints location in relation to HXB2, estimated using jpHMM.

\begin{tabular}{|c|c|c|c|c|}
\hline Isolate & $\begin{array}{c}\text { Fragment } \\
\text { Start Position }\end{array}$ & $\begin{array}{c}\text { Breakpoint Interval } \\
\text { Start - End }\end{array}$ & $\begin{array}{l}\text { Fragment End } \\
\text { Position }\end{array}$ & $\begin{array}{c}\text { Fragment } \\
\text { Subtype }\end{array}$ \\
\hline \multicolumn{5}{|l|}{ 0008SP } \\
\hline & 638 & - & 789 & N/A \\
\hline & 790 & $1324-1392$ & 1350 & B \\
\hline & 1351 & $1701-1724$ & 1717 & $\mathrm{~F} 1$ \\
\hline & 1718 & $2064-2099$ & 2066 & B \\
\hline & 2067 & $2317-2415$ & 2375 & $\mathrm{~F} 1$ \\
\hline & 2376 & $3723-3812$ & 3811 & B \\
\hline & 3812 & $5148-5178$ & 5162 & F1 \\
\hline & 5163 & $5282-5310$ & 5309 & B \\
\hline & 5310 & $5508-5839$ & 5816 & F1 \\
\hline & 5817 & $8663-8680$ & 8668 & B \\
\hline & 8669 & $8962-9021$ & 8983 & $\mathrm{~F} 1$ \\
\hline & 8984 & - & 9408 & B \\
\hline & 9408 & - & 9536 & N/A \\
\hline \multicolumn{5}{|l|}{ 0063SV } \\
\hline & 760 & - & 789 & N/A \\
\hline & 790 & $1220-1378$ & 1227 & B \\
\hline & 1228 & $2488-2551$ & 2541 & $\mathrm{~F} 1$ \\
\hline & 2542 & $3707-3780$ & 3712 & B \\
\hline & 3713 & $5791-5828$ & 5824 & F1 \\
\hline & 5825 & - & 9411 & B \\
\hline & 9412 & - & 9576 & N/A \\
\hline \multicolumn{5}{|l|}{ 0264SV } \\
\hline & 720 & - & 789 & N/A \\
\hline & 790 & $1238-1324$ & 1322 & B \\
\hline & 1323 & $2501-2551$ & 2541 & F1 \\
\hline & 2542 & $3680-3730$ & 3691 & B \\
\hline & 3692 & $5802-5842$ & 5824 & $\mathrm{~F} 1$ \\
\hline & 5825 & - & 9411 & B \\
\hline & 9412 & - & 9574 & N/A \\
\hline \multicolumn{5}{|l|}{ 0614SV } \\
\hline & 782 & - & 789 & N/A \\
\hline
\end{tabular}




\begin{tabular}{|c|c|c|c|c|}
\hline & 790 & $1210-1259$ & 1226 & B \\
\hline & 1227 & $2518-2551$ & 2534 & F1 \\
\hline & 2535 & - & 9411 & B \\
\hline & 9412 & - & 9579 & N/A \\
\hline & & & & \\
\hline \multirow[t]{5}{*}{ 0632SV } & 708 & - & 789 & N/A \\
\hline & 790 & $6543-6583$ & 6583 & B \\
\hline & 6584 & $7654-7731$ & 7658 & F1 \\
\hline & 7659 & - & 9411 & B \\
\hline & 9412 & - & 9479 & N/A \\
\hline \multirow[t]{7}{*}{ 0647SV } & 758 & - & 789 & N/A \\
\hline & 790 & $1210-1333$ & 1220 & B \\
\hline & 1221 & $2466-2549$ & 2517 & F1 \\
\hline & 2518 & $3681-3745$ & 3705 & B \\
\hline & 3706 & $5767-5863$ & 5789 & F1 \\
\hline & 5790 & - & 9411 & B \\
\hline & 9412 & - & 9562 & N/A \\
\hline \multirow[t]{5}{*}{ 0679SV } & 631 & - & 789 & N/A \\
\hline & 790 & $1231-1392$ & 1350 & B \\
\hline & 1351 & $2486-2547$ & 2517 & F1 \\
\hline & 2518 & - & 9411 & B \\
\hline & 9412 & - & 9570 & N/A \\
\hline \multirow[t]{5}{*}{ 0736SV } & 782 & - & 789 & N/A \\
\hline & 790 & $1222-1378$ & 1227 & B \\
\hline & 1228 & $2283-2351$ & 2307 & F1 \\
\hline & 2308 & - & 9407 & B \\
\hline & 9407 & - & 9589 & N/A \\
\hline \multirow[t]{4}{*}{ 0744SV } & 859 & $1227-1259$ & 1259 & B \\
\hline & 1260 & $2500-2551$ & 2541 & F1 \\
\hline & 2542 & - & 9411 & B \\
\hline & 9412 & - & 9529 & $\mathrm{~N} /$ \\
\hline
\end{tabular}


ANEXO C - LISTA DE PUBLICAÇÕES 


\section{Lista de Publicações}

Romano CM, de Carvalho-Mello IM, Jamal LF, Melo FL, Iamarino A, Motoki M, Pinho JR, Holmes EC, de Andrade Zanotto PM. Social networks shape the transmission dynamics of hepatitis C virus. PLoS ONE. 2010;5:e11170.

Melo FL, Romano CM, de Andrade Zanotto PM Introduction of dengue virus 4 (DENV-4) genotype I into Brazil from Asia? PLoS Negl Trop Dis.2009: 3:e390

Alcalde R, Melo FL, Nishiya A, Ferreira SC, Langhi MD, Fernandes SS, Marcondes LA, Duarte AJ, Casseb J. Distribution of hepatitis B virus genotypes and viral load levels in Brazilian chronically infected patients in Sao Paulo city. Rev Inst Med Trop Sao Paulo. 2009: 51(5):269-272.

de Castro Oliveira JV, Melo FL, Romano CM, Iamarino A, Rizzi TS, Yeda FP, Harsi CM, Wolff JL, de Andrade Zanotto PM. Structural and phylogenetic relationship of ORF 31 from the Anticarsia gemmatalis MNPV to poly (ADP-ribose) polymerases (PARP). Virus Genes. 2008: $37: 177-84$.

Freitas RB, Melo FL, Oliveira DS, Romano CM, Freitas MR, Macedo O, Linhares AC, de AZPM, Durigon EL. (2008) Molecular characterization of human erythrovirus B19 strains obtained from patients with several clinical presentations in the Amazon region of Brazil. J Clin Virol. 2008:43:60-5.

Melo FL, Benati FJ, Roman WA, Jr., de Mello J.C., Nozawa C, Linhares RE. (2008) The in vitro antiviral activity of an aliphatic nitro compound from Heteropteris aphrodisiaca. Microbiol Res. 2008: 163:136-9.

Ramsden C, Melo FL, Figueiredo LM, Holmes EC, Zanotto PM. High rates of molecular evolution in hantaviruses. Mol Biol Evol. 2008: 25:1488-92.

Romano CM, Melo FL, Corsini MA, Holmes EC., Zanotto PM Demographic histories of ERV-K in humans, chimpanzees and rhesus monkeys. PLoS ONE. 2007: 2:e1026.

Freitas RB, Durigon EL, Oliveira DS, Romano CM, Freitas MRC, Linhares, AC, Melo FL, Walshkeller L, Barbosa ML, Huatuco EM, Holmes EC, Zanotto PM. (2007) The "pressure pan" evolution of human erythrovirus B19 in the Amazon, Brazil. Virology. 2007: 369:281-7. 